\title{
Records of Trade and Transaction
}

Economic records of Western Xia include not only transaction and loan contracts, which contain direct information on Tangut trade, but also a batch of statistical accounts that provide us with larger data on Tangut trade. Such a record is not of each single sale and purchase but rather of numerous interwoven commercial activities. Therefore, they offer us a historical lens through which it is now possible to take a fuller and broader glance at Tangut trade and transactions on the ground.

\section{1 \\ Transaction Accounts and Commodity Prices}

Commodity prices are an important economic factor in the stability and prosperity of an imperial economy. Market prices of common merchandise are central to civic livelihood. It is, therefore, no exaggeration to say that price is an integral step to studying the economic lives of past societies. In general, Chinese archives lack information on commodity prices in Western Xia. In the Khara-Khoto manuscripts, however, Tangutologists have found a sizable corpus of trade records that include the types, quantities, and prices of the goods transacted. These precious manuscripts provide us with the primary sources with which we are now able to touch the vital pulses of Tangut economy.

\subsection{Accounts of Grain Sales and the Prices of Grain}

Grains are the most important supply of nutrition in the agricultural societies of medieval Inner and East Asia; hence, they are also the most indispensable commodity in Tangut markets. Therefore, although most of the accounts of grain prices excavated in Khara-Khoto have only survived as incomplete fragments, these manuscripts have remained precious primary sources, which provide us with the data necessary to analyse and calculate the market prices of grains at the time. It is, of course, unnecessary to elaborate at length the significance of data on food prices for historians trying to understand the history of agriculture, commerce, and other aspects of economic lives in Western Xia.

The Russian Manuscript Инв. No. 1167 contains multiple pieces of documents, the first three of which reflect the grain prices in Western Xia. The manuscript Инв. No. 1167-1, $(21.5 \times 31.9 \mathrm{~cm}$, handwritten on hemp-paper and with damages at the beginning and the end) features six lines of cursive Tangut. 


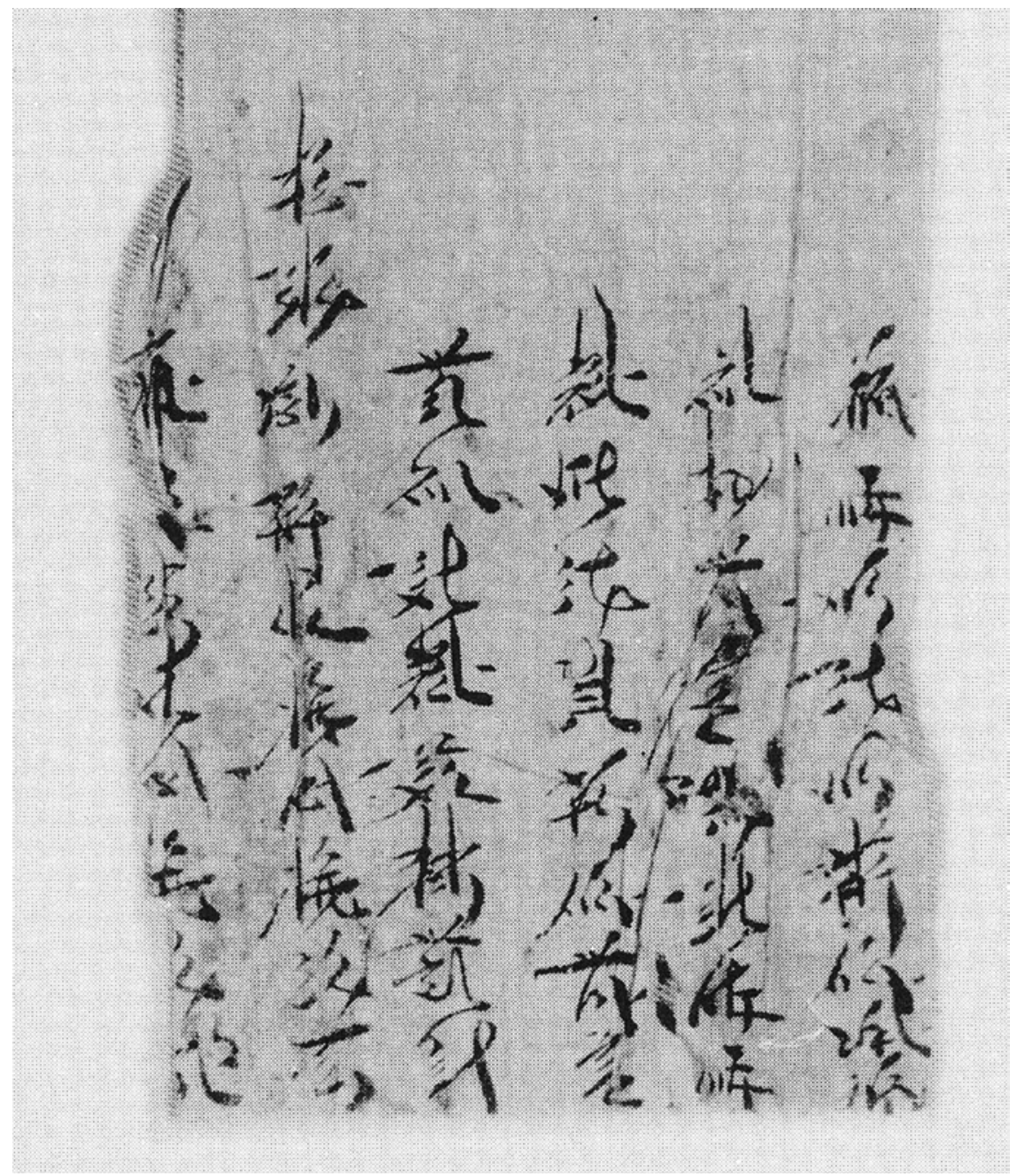

FIGURE 70 Инв. No. 1167-1: Account of grain sales

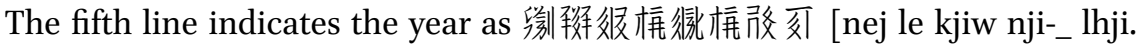
nji-_ ya. lew] "Ren-yin Year, second month, twenty (two ten)-first." The manuscript Инв. No. 1167-3 (likewise, hemp-paper fragment, $21.5 \times 13.6 \mathrm{~cm}$ ) features seven lines of cursive Tangut. Finally, the Инв. No. 1167-2 (hemp-paper fragment, $21.5 \times 8.1 \mathrm{~cm}$ ) has four lines of Tangut cursive. The first line begins with the two characters 瓶轧 [du_tser] “Gui Mao," a year apart from 1167-1. ${ }^{1}$

Russian Manuscript Инв. No. 1167-1, an account of grain prices, lists transactions in order and by items. Line 5 , for example, switches to a new line with

1 Russian Collection of Khara-Khoto Manuscripts 12, pp. 193-194. 


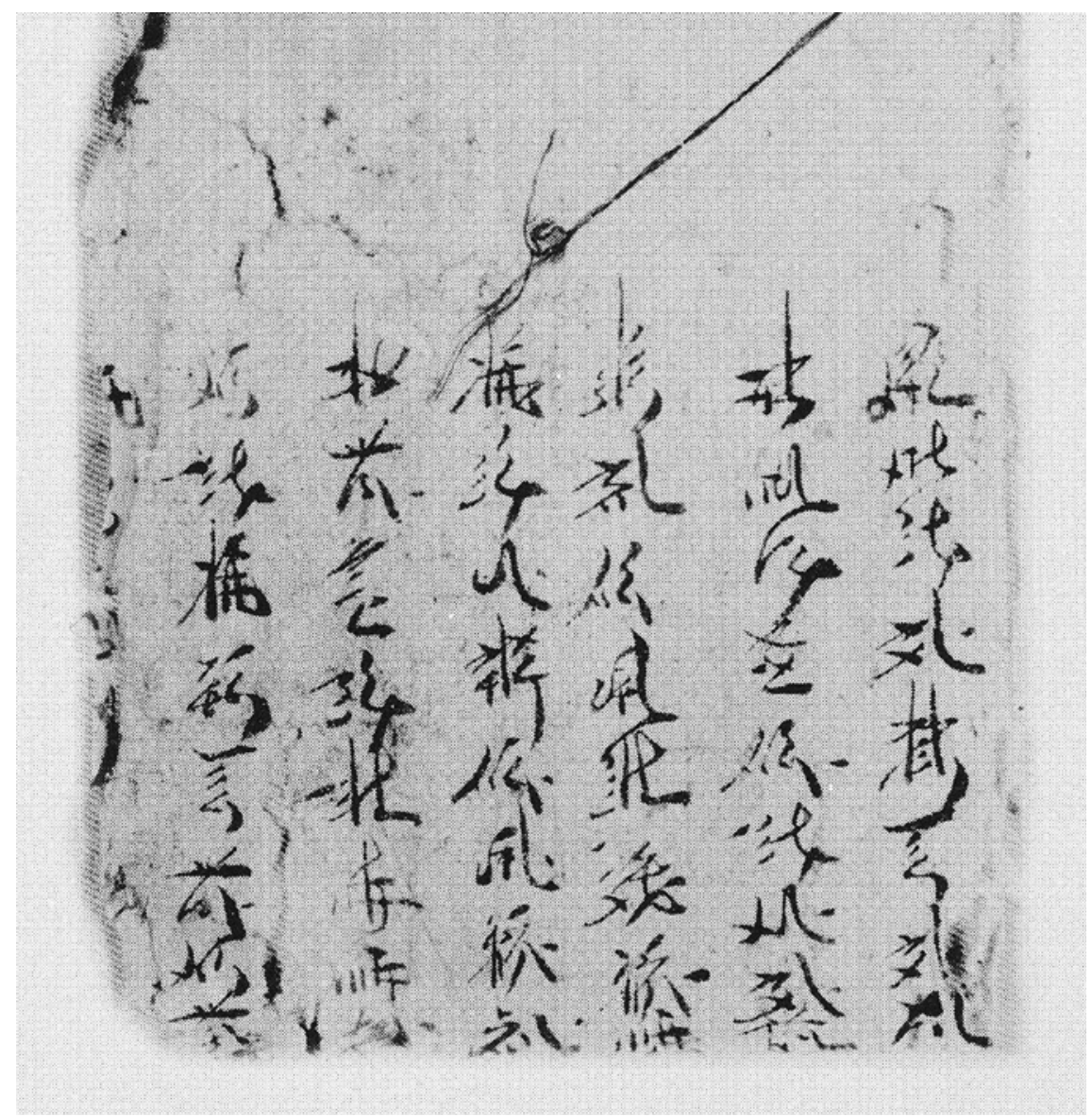

FIGURE 71 Инв. No. 1167-3: Account of grain sales

the two characters: 稊斏, “one item," i.e. the start of a new item on the list. Lines 1-4 make up the content of the previous item:

Cash in total: 44 guan 500 qian,

Assorted Grains 1 dou/7o counts (qian), total

Grains 63 dan 5 dou 7

sheng of assorted grains, placed in the grain storage.

The above content concerns the calculation of grain prices. 'Assorted grains' (again, general reference to coarse cereals and miscellaneous grain crops) are priced at 70 qian/dou. Based on this unit price, a total of 63 dan, 5 dou, and 7 sheng of grains are supposed to cost 44 guan and 499 qian in total sum of 
money, which show up in the manuscript as 44 guan and 500 qian, with 499 rounded to 5 оо in customary practice. A similar type of manuscript is Инв. No. 1167-3, which records the following information:



With the sum of 29 guan and 500 qian, and at the price of 70 qian per dou, one could have purchased exactly a total of $42 \mathrm{dan}, 7 \mathrm{dou}$, and 4 sheng of grains. The Russian manuscript Инв. No. 1167-2 is another account of grain prices. Despite even more damages, its fourth line gives the same price: "assorted (grains), one dou, 70 counts (qian)." These several manuscripts suffice to show that the general market price of miscellaneous grains in the Khara-Khoto area at the time was 70 qian per dou.

Тhe Инв. No. 1167-3 seems to calculate the price in the period of two months, with one of them subtracted by one day, probably because it was a leap month, which leaves us with 59 days left, at the price of 500 qian per day. It still remains difficult to determine what type of payment it is referring to, though it might be the wage of a worker. The manuscript is all the more precious because it gives away the grain price of the day and has thus become one of our most invaluable economic-historical sources.

The manuscript Инв. No. 1167-1 marks the "Ren-yin Year," whilst Инв. No. 1167-2 mentions both the "Gui-mao" and the "Jia-chen." Considering that most of the Khara-Khoto documents date to the late period of Western Xia, it makes a certain amount of sense to suppose these years to be the final three occurrences of "Ren-yin," "Gui-mao," and "Jia-chen" in the history of Western Xia: the thirteen (1182), the fourteenth (1183), and fifteenth (1184) years of Renzong's reign Qianyou, respectively. Given this time frame, it is possible that the price of 70 qian per dou of assorted grains reflected the market price of grains in Khara-Khoto during Renzong's reign.

There are also other types of cash and grain accounts in the corpus of Khara-Khoto manuscripts. The manuscript Инв. No. 2042-2 (handwritten on $10.8 \times 30.5 \mathrm{~cm}$ fragment hemp-paper as a book-cover page, with 11 lines of 


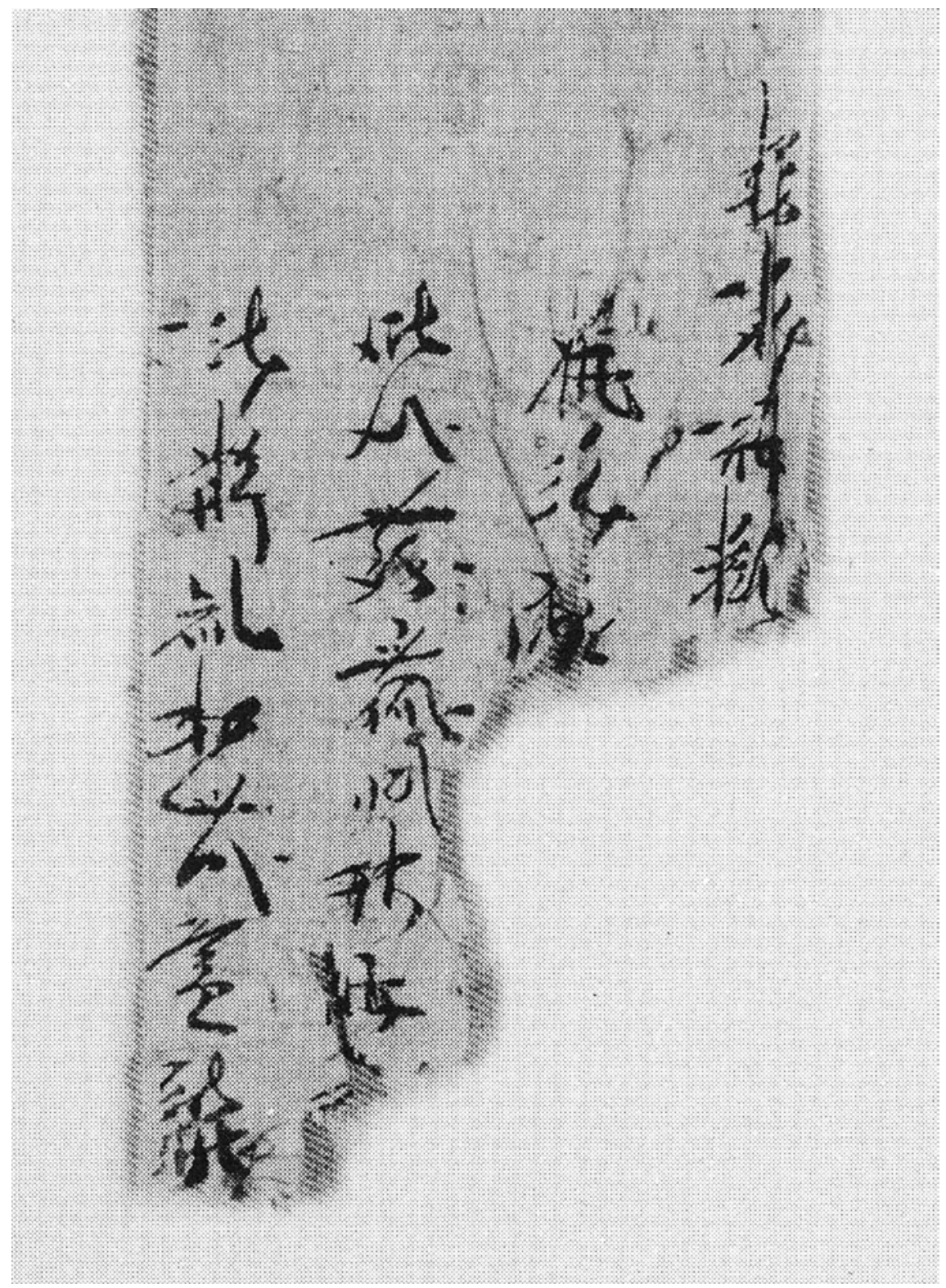

FIGURE 72 Инв. No. 1167-2: Account of grain sales 


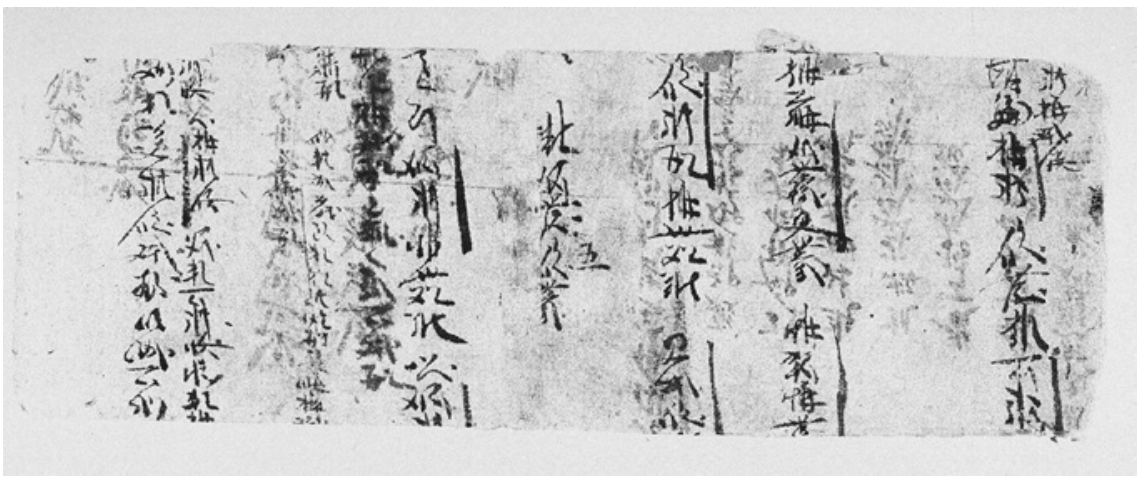

FIGURE 73 Инв. No. 2042-2: Account of cash and grains

Tangut cursive writings mixed with some Chinese characters) provides such an example. ${ }^{2}$

Line 2 reads, " 5 dou of millet, 1 guan"; lines 3-4: "2 dan 2 dou? 5 guan to retrieve"; lines 4-5: "80o \& 50 qian, 4 dou 5 sheng." Millet is considered one of the coarse or miscellaneous grains. However, according to the calculations in this manuscript, the unit price of millet grains was set at around 200 qian, far from the 70 qian derived from previous documents. But it is worth noting that the manuscripts we have looked at so far mostly label the cash unit qian as copper coins (tongqian), which were at the time worth more than iron coins in Western Xia. The copper-to-iron ratio in value was roughly 2.8:1. ${ }^{3}$ The concerned document we have at hand does not specify what type of coin is in reference. But suppose the qian really are iron coins, then 70 copper coins qian $\times 2.8=196$ iron coins qian, which falls more or less in line with the 200 qian derived from the present manuscript. One possible explanation for the variance in price units is that the previous manuscripts date to the Renzong era, when the Tangut society was relatively stable, whereas the later manuscripts reflect the economic instability of Western Xia. It is possible that social unrest towards the final years of the Empire affected the commodity prices and availability of cash.

On the layering paper of a text's cover page in the National Library of China collection of Khara-Khoto manuscripts, scholars have found a piece of Tangut account of grain sale, No. $010(7.04 \mathrm{X}-1){ }^{4}$ There are 13 lines of Tangut cursive

2 Russian Collection of Khara-Khoto Manuscripts 13, p. 17.

3 See later discussion on the price of horses.

4 No. 010 and 7.04X-1 are registered numbers for Khara-Khoto manuscript fragments at the National Library of China. 
written on a yellowish hemp paper, despite damages both on the top and at the bottom. The document records the date of the grain sale, the names of the personalities involved in the transaction, the types of grains, and the price. The lines are mostly incomplete, with some lacking data on the quantity of grains while others missing the price numbers.



FIGURE 74 National Library of China, No. 010 (7.04X-1): Account of grain sales

The following is a rough translation:

May 16th, Lady Hao $\square \square$ wheat, millet, 4 dou ...

August 8th, 1 guan 200

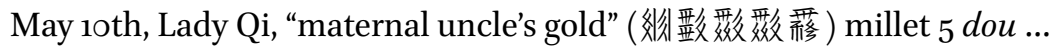

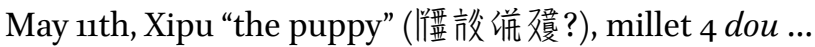

June 4th, Zhang "the joyful dog" 1 guan, borrows 9 ...

May 16th, Jia?jiu (㹨? 军), wheat 2 dou, price 400 ...

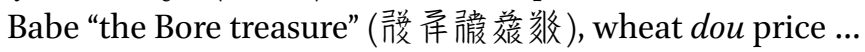

May 16th, Babe "the Bore treasure," wheat 3 dou price ...

May 11th, $\square \square$ "Puppy" 7 dou millet price 1 guan ...

500 , once again 500 ,

May 11th, Zhang Jingle, dou wheat millet 1 dan ...

August 8th ...

August ...

Information on the prices are preserved to the most extent in lines 6 and 9 . Line 6, for example, lists "wheat 2 dou price 4 ..." - the half of the character that follows 4 should be the character for 'hundred.' The price for 2 dou of wheat equals or exceeds 400 qian, but below 500 qian. We know, therefore, that the unit price of wheat in that local area ranged from 200 to $25^{\circ}$ per dou, 
or 20-25 qian per sheng. From line 9, "7 dou of millet, price 1 guan ..." we learn that the price of millet falls in the range of 100-20o qian per dou, or that the price of millet per dan is somewhere between 1 and 2 guan. In general, millet is cheaper than wheat. So, although the price of 7 dou of millet equals or exceeds 1 guan, it could hardly reach 1 guan and 750 qian, which would be the highest price of wheat (250 qian per dou). It is possible to infer the unit price per dou of millet to be around 150-200 qian, or $15^{-20}$ qian per sheng. ${ }^{5}$ Despite all the missing information due to manuscript damages, this document provides scholars with the price of the most important commodity in the Tangut market: the price of refined and coarse grains in Tangut-controlled Khara-Khoto. Furthermore, these prices appear to be in line with the figures derived from the aforementioned manuscript Инв. No. 2042.

Chinese historical archives also make some sparse mentions of Tangut grain prices, but mostly in abnormal times of emergency. In the most painful years of Yuanhao's reign, ceaseless wars of combat and attrition wore out the economies of Western Xia. With the Tangut populations reduced and impoverished, armies drained of manpower, and commodity prices soaring out of control, the Tanguts ultimately asked for and accepted the Peace Treaty of Qingli. In September of the third year of Daqing in Western Xia (1142), "with Western Xia suffering a famine, the price of rice in the civil market soars by a hundred qian." ${ }^{\prime 6}$ Due to the shortage of grains, food prices rose to unprecedented heights, almost four to five times of the normal price.

When the Song Emperor Renzong reigned, (mid-11th century), the price of rice per dan was 6oo-70o qian, subsequently increased to 1 guan 250 wen (qian), roughly 12.5 wen (qian) per sheng. In the era of Southern Song, price of rice per dan was 1 guan 500 wen, which at times rose to about 2 guan, roughly 20 wen per sheng. In the fourth year of Jiaxi, under Southern Song's Lizong Emperor (1240), the city of Lin'an suffered a severe famine. ${ }^{7}$ At the time, the price of rice per dan reached 10 guan, or 100 qian per sheng. From this comparative perspective, it seems that grain prices in Song and Xia were quite similar, and in both cases, as was elsewhere, harvests, natural catastrophes, and political events affect the rise and fall of grain prices.

5 Shi, Jinbo. “Guojia Tushuguan Cang Xixiawen Shehui Wenshu Canye Kao” [國家圖書館藏 西夏文社會文書殘頁考]: “A Study of Manuscript Fragments of Tangut Social Documents at the National Library of China" in Wenxian [文獻] Documents, issue 2, 2004.

6 Xixia Shushi, Ch. 35 .

7 TN: Jiaxi (嘉熙; 1237-124O AD), which lasted for four years, is the fourth era name of Emperor Lizong's reign. 


\subsection{Accounts of Livestock Sales and the Prices of Livestock}

Livestock husbandry and pasturing is the traditional economic industry of the Dangxiang Tanguts, the ruling majority ethnic group of Western Xia. In the Tangut livestock economy, sheep, horses, cattle, and camels were the four main species of animals. The raising, loaning, and selling of livestock, the main produce of Western Xia, is the characteristic productive and commercial activity of the Tanguts. A careful reading of the manuscripts that document these exchanges also reveals the rituals and prices of animal transactions in Western Xia.

\subsubsection{Price of Sheep}

The price of sheep may be derived from several Khara-Khoto manuscripts that feature accounts of sheep transactions. For example, the Инв. No. 1219 is such a manuscript fragment that features an account of transaction prices. The manuscript Инв. No. 1219-1 and Инв. No. 1219-3 are supposed to be two parts of a connected account of transaction prices. Handwritten on hemp-papers and $36.9 \times 9.2 \mathrm{~cm}$ and $36.9 \times 13.4 \mathrm{~cm}$ in size, they feature five and seven lines of cursive Tangut, respectively, and contain some marks of edits and erasures. ${ }^{8}$

The following is a literal translation of the manuscript Инв. No. 1219-1 (lines 2-4):

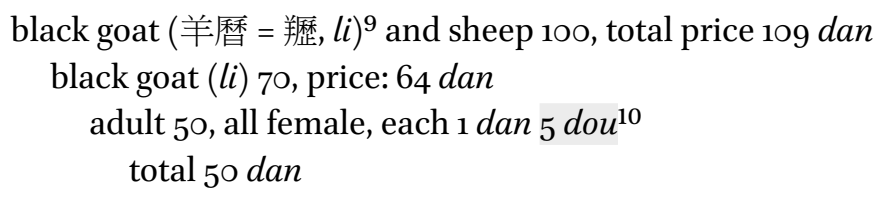

Russian Manuscript Инв. No. 1219-3 (lines 1-4, following the previous text). The following is a literal translation:

Lamb 20, all male, each 7 dou, total

$$
2(1) 4^{11} \text { dan }
$$

Sheep 30, all adult female, each 1 dan 5

dou, total 45 dan.

8 Russian Collection of Khara-Khoto Manuscripts 12, pp. 222-223.

9 TN: the original text has only two characters. It is the translator's choice to add the composed character, 䍽 $l i$, which is roughly a synonym of 羖 $g u$ : male goat, sometimes black, usually fierce, occasionally castrated, depending on the time and context.

10 TN: The corresponding shaded characters are first written on the manuscript and then erased/deleted by the author, probably in order to correct the typo.

TN: likewise, the correct figure is 14. The author corrected the typo. 


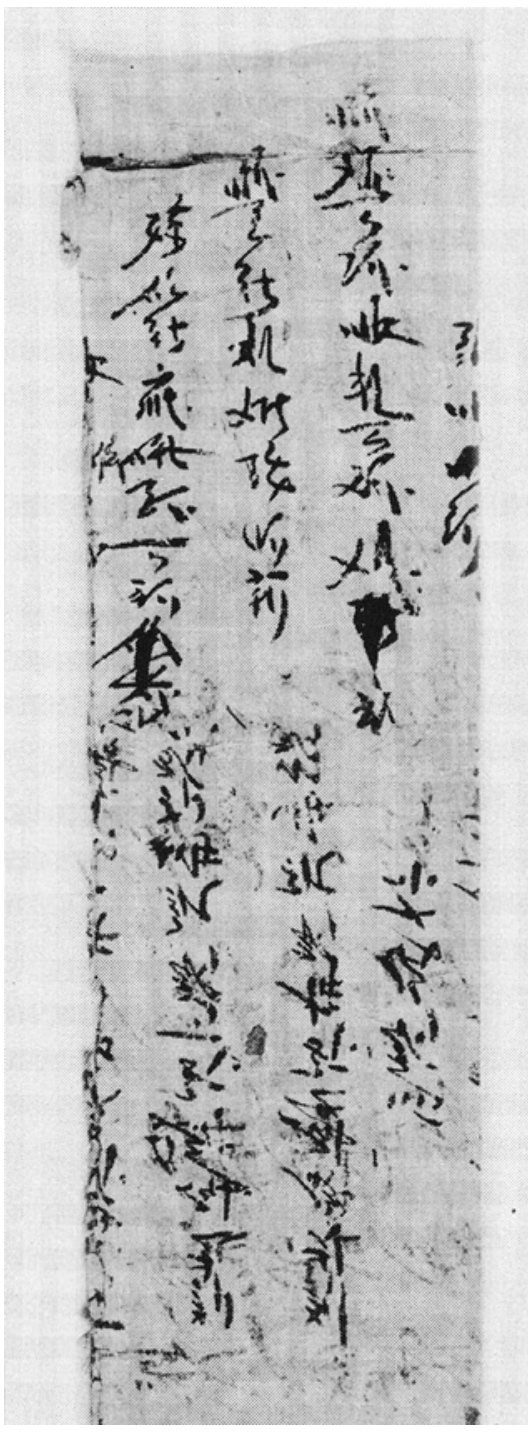

FIGURE 75 Инв. No. 1219-1: Account of transaction prices

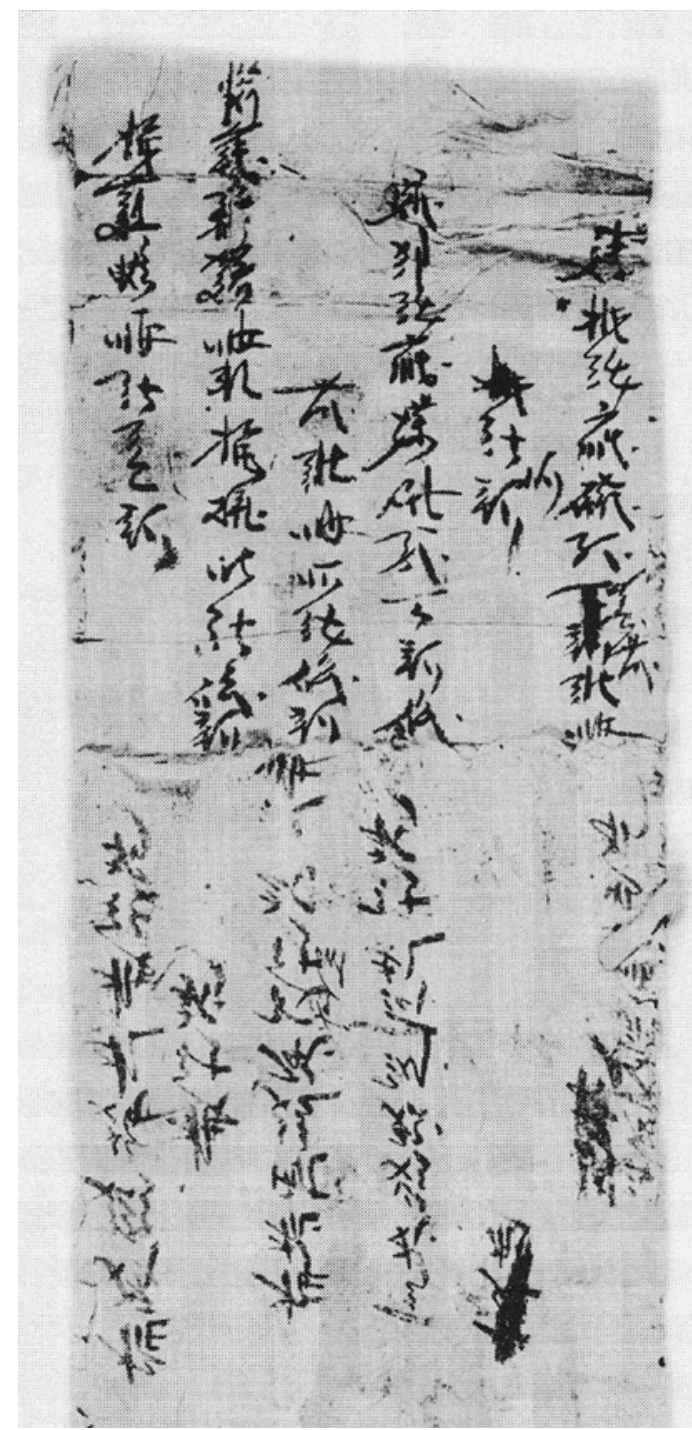

FIGURE 76 Инв. No. 1219-3: Account of transaction prices

The sale and purchase recorded in this manuscript involve 10o black goat and

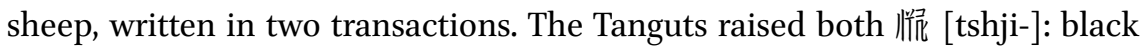

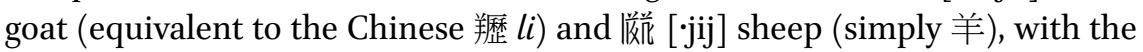
Capra and the Ovis clearly distinguished in the terms set by the Fan-Han Timely Pearl in the Palm.12 The document begins with the first transaction of 70 black

12 Russian Collection of Khara-Khoto Manuscripts 10, p. 9. 
goats: 50 adults and 20 smalls. Understandably, sexually mature rams and juvenile lambs were priced differently. Each of the 50 adult rams was worth 1 dan of grains, which makes a total of 50 dan. Every one of the 20 small black goats were priced at $7 \mathrm{dou}$, which amounts to a total of 14 dan. Combined, the rams are sold at the price of 64 dan. The other transaction was much simpler. All 30 sheep sold were female adults, which were the highest-priced: 1 dan 5 dou, making the total cost of purchase 45 dan of grains. The combined volume of the two transactions was 109 dan, which accords exactly with the figure given in the manuscript.

Evidently, the price of livestock depended on the species and sex of the animals in question. The unit price of black goats, 1 dan, was $2 / 3$ that of a female sheep, 1 dan 5 dou. The manuscript 1219-1 seems to have first recorded the price of black goat at 1 dan and 5 dou. Apparently, a typo, the 5 dou was then crossed out from the manuscript. Likewise, adult goats and small lambs were priced differently. The price of a lamb, $7 \mathrm{dou}$, was $70 \%$ that of the same goat when it grew into maturity, 1 dan.

So far, the price of sheep is expressed in terms of another commodity: the grains. Given the 200 qian per dou price of miscellaneous grains, we may now calculate the unit monetary price of each small black goat (lamb) to be 1 guan-1 guan 400 wen/qian. The price of each adult black goat was 1 guan 500 wen/qian-2 guan. Each adult female sheep was worth 2 guan 250 wen/ qian-3 guan.

\subsubsection{Price of Horses}

Historically known for pasturing, the Dangxiang people continued to raise excellent horses after their migration to what is today northwest China. Indeed, Dangxiang horses were the main source of steeds in the Chinese Central Plains. The reputation of Tangut horses dates back further to the Tang Dynasty, when the celebrated poet Yuan Zhen sang of "Procuring Dangxiang horses from the North, and fetching Tibetan parrots from the West."13 Since the Five Dynasties, Dangxiang had sold horses en masse to empires in the Central Plains. During the reign of Mingzong Emperor of the Later-Tang:

When the Imperial Majesty issues an edict to establish posts along the frontiers in order to trade horses, the many barbarians all entered

\footnotetext{
13 Guo, Maoqian (郭茂倩, Song Dynasty). Yuefu Shiji [樂府詩集] Anthology of Yuefu Poetry. Sibu Congkan Edition (四部叢刊) edited by Zhang, Yuanji et al. Shanghai: Commercial Press, 1922. Book 48, Lyrics for Songs in the Pure Shang Mode (清商曲辭五), Western Songs (西曲歌), Music of Traveling Merchants (估客樂), Yuanzhen (元稹).
} 
the markets of the Middle Kingdom. There were the Uyghurs, but the Dangxiang boasted the greatest number of horses. ${ }^{14}$

The Song Dynasty, which suffered chronic shortages of horses, sought horses from many lands and territories, which of course include the pasture lands under Tangut rule.

In the early period of the Song Dynasty, horses were traded only in the three districts of Hedong, Shaanxi and Chuanxia. Horses were only imported from the Tibetans, Uyghurs, Dangxiang ... and the many barbarian peoples. ${ }^{15}$

In Western Xia, horses not only constituted the regime's main export but also provided for agricultural and military use within its territories. For these reasons, the price of horses was extremely sensitive. When the Laws of Heavenly Prosperity mentions the confiscation of horses as a penalty, it indirectly provided us with some information on horse prices:

Those who on account of their criminal guilt are punished with the confiscation of horses, are required to turn over their excellent, family-trained horses of sound teeth. If it is true that they cannot suffer the burden of losing these horses, then they should at least find the appropriate guarantors, and pay instead 20 guan in cash as the converted price of each horse. ${ }^{16}$

From the text above, we know that a Tangut horse was worth roughly 20 guan. In most cases, the converted price of an otherwise confiscated horse was slightly above the market price of a new horse.

There is an account of horse prices in the midst of the Khara-Khoto manuscripts: the document No. 1763 , which has great value as a primary source on horse prices in Tangut markets. Handwritten on a $32.8 \times 27.5 \mathrm{~cm}$ hemp-paper found within a book cover and patched together out of separate fragments, the manuscript features nine lines of Tangut in the cursive. ${ }^{17}$

\footnotetext{
14 Old History of the Five Dynasties, Bk. 138, "On Foreign States II."

15 History of Song, Bk. 198, "On Military Institutions."

16 Revised Laws of Heavenly Prosperity 20, "On the Various Levels of Criminal Responsibility," p. 602.

17 Russian Collection of Khara-Khoto Manuscripts 12, p. 311.
} 


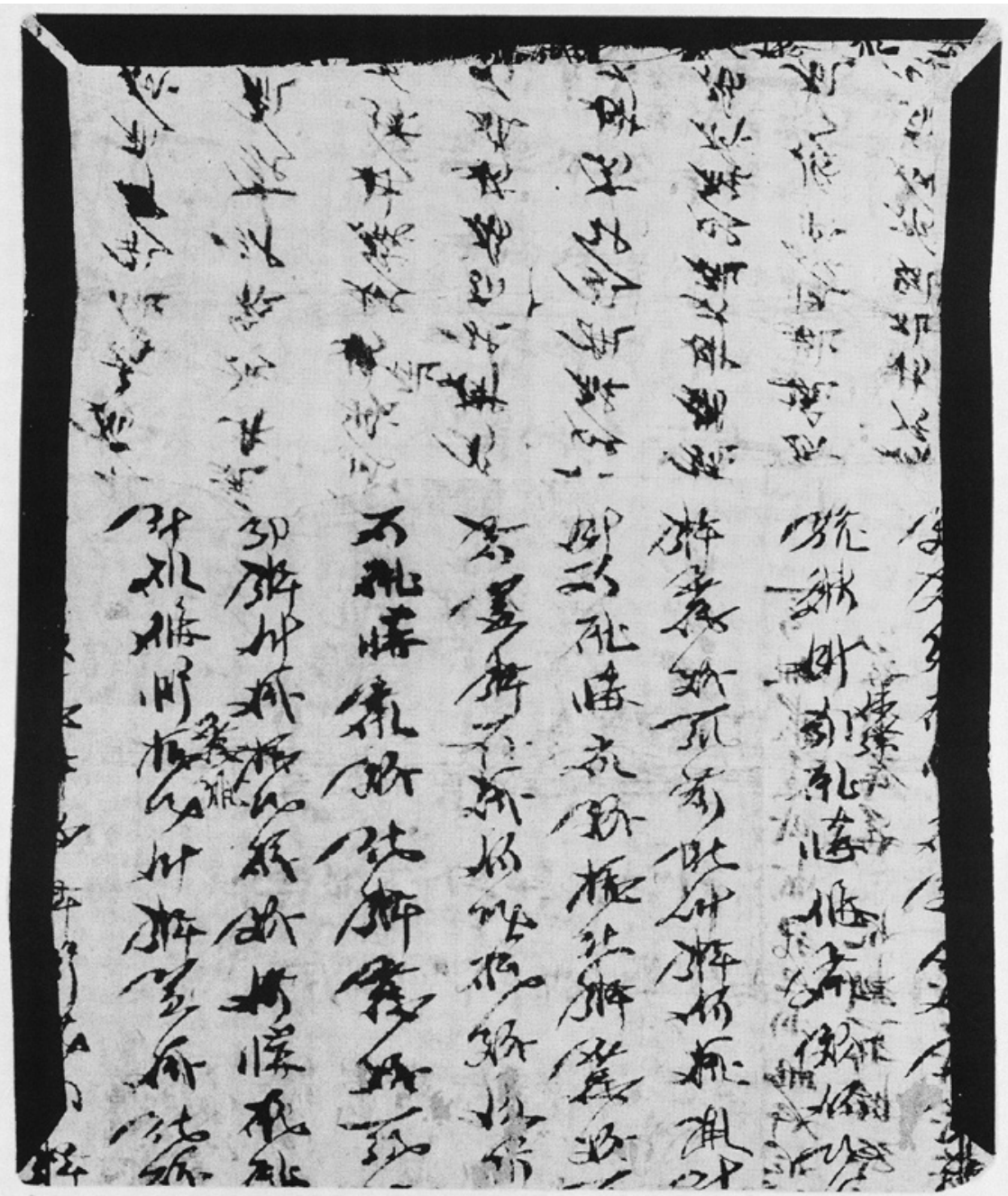

FIGURE 77 No. 1763: Account of horse prices

In the manuscript, lines 1-2 mention "of the three horses large and small, the total sum is 40 iron qian ? guan, copper coins 16 guan"; lines 3-4 read, "one horse counts iron coins 20 guan, or in copper coins, 7 guan 145 qian"; lines $5^{-6}$, "one horse counts iron coins 10 guan, in copper coins 3 guan 625 qian"; lines $6-7$ contains the total statistics of three horse transactions: "five horses ... copper coins 26 guan 710 qian."

First of all, the document records the unit price of a horse: three horses were worth $40+$ guan of iron coins, one other horse was worth 20 guan of iron coins, and yet another one was worth only 10 guan. Of course, prices differed 
given the ages and strengths of particular horses, but it is still possible to infer from the text above that the unit price of a horse in the market was roughly 10-20 guan in (iron) cash.

This document is curious for another reason: it not only lists the various prices of horses, but it also renders the statistics both in copper and in the converted currency of iron coins. In this period, Western Xia suffered a shortage of copper so severe that the empire had no other recourse than to mint iron coins en masse. Trading with both currencies, the Tanguts circled out special zones for the use of copper and iron, respectively. According to the Laws of Heavenly Prosperity,

The many are not allowed to transport the black iron coins from the Southern Realm to the Imperial Capital, or to relocate the copper coins from the Imperial Capital to the Southern Realm, etc. In case the law is violated, whether by a few or many, all perpetrators are sentenced to two years of imprisonment. ${ }^{18}$

The so-called "Southern Realm" refers to the area around Liangzhou, which includes iron-circulated Khara-Khoto. The two currencies were swapped at the market rate, which has been unknown until recently. This document, for example, records the iron to copper ratio in the context of labelling the horse prices in different types of coins. In the first transaction, the digit after 40 guan is missing. So, although the sum should be between 40 and 50 guan, we do not know yet how to make the conversion. The second and third transactions, however, provide full data in the iron and copper cash, which makes it possible to calculate the currency rate:

CHART 8 Инв. No. 1763: Account of horse prices, statistics

\begin{tabular}{lllll}
\hline & $\begin{array}{l}\text { Number } \\
\text { of horses }\end{array}$ & $\begin{array}{l}\text { Iron coins } \\
\text { (qian) }\end{array}$ & $\begin{array}{l}\text { Converted to copper } \\
\text { coins (qian) }\end{array}$ & Copper: Iron \\
\hline Transaction 1 & 3 & $\begin{array}{l}4 \text { ? guan } \\
\text { 20 guan }\end{array}$ & $\begin{array}{l}\text { 16 guan 400 qian } \\
\text { 7 guan 145 qian }\end{array}$ & 2.799 \\
Transaction 2 & 1 & 10 guan & 3 guan 625 qian & $2.75^{8}$ \\
Transaction 3 & 1 & & & \\
\hline
\end{tabular}

18 Revised Laws of Heavenly Prosperity 7, "Imperial Prohibitions," p. 287. 
If we take the conversion rate that every 1 guan in copper was worth about 2.8 or 2.75 guan in iron, it is possible to calculate the price in the first transaction of iron coins. At the ratio of 2.8, the 16 guan 400 qian in copper coins amounts to 45.92 guan in iron coins, or approximately 46 guan. At a ratio of 2.75 , the result of the conversion is about 45.1 guan in iron, or around 45 guan. The total sum of the three transactions is $7.145+3.625+16.4=27.17$ in copper coins, which is 460 qian more than the sum as stated in the manuscript: 26 guan 710 qian. Therefore, it is fitting to fill in the missing digit in the first column to make it 46 guan. The following chart shows why 46 guan is the reasonable guess:

снARт 9 Инв. No. 1763: Account of horse prices, appendix to transaction 1

\begin{tabular}{|c|c|c|c|}
\hline & $\begin{array}{l}\text { Iron coins } \\
\text { (qian) }\end{array}$ & $\begin{array}{l}\text { Converted to copper } \\
\text { coins (qian) }\end{array}$ & Copper: Iron \\
\hline Transaction 1 & 46 guan & 16 guan 400 qian & $2.804 \approx 2.8$ \\
\hline Total & 76 guan & 27 guan 17 qian & $2.797 \approx 2.8$ \\
\hline
\end{tabular}

This manuscript fragment confirms the market price of horses in the Khara-Khoto area to be between 10 and 20 guan in iron coins, which is approximately $3 \cdot 5^{-7}$ guan in copper coins. Moreover, it sets iron-to-copper ratio at about 2.8:1. Both horse prices and the copper-to-iron conversion rate are critical economic information.

In general, it is possible to derive precise commodity prices from records of particular transactions that took place in Western Xia, such as Tangut transaction contracts found in Khara-Khoto that list the prices of livestock directly on the document. The Russian Manuscript Инв. No. 5404-10, dated to the $\mathrm{Zi}$ year of Tianqing (1204), is such a livestock-transaction contract, with 12 lines of Tangut in the cursive. ${ }^{19}$

Lines 3-4 list the prices of livestock: a horse of five teeth was worth 4 dan miscellaneous coarse grains, roughly equivalent to $6-8$ guan.

Compared to prices in Tangut markets, prices of horses in the Song Dynasty were usually exorbitantly high. In the Northern Song era, a horse was regularly priced at 30-50 guan, while the more famous were worth up to 70, 80, and even 100 guan. In Southern Song, a 300-40o guan per horse was the norm. Given

19 Russian Collection of Khara-Khoto Manuscripts 14, p. 35. 


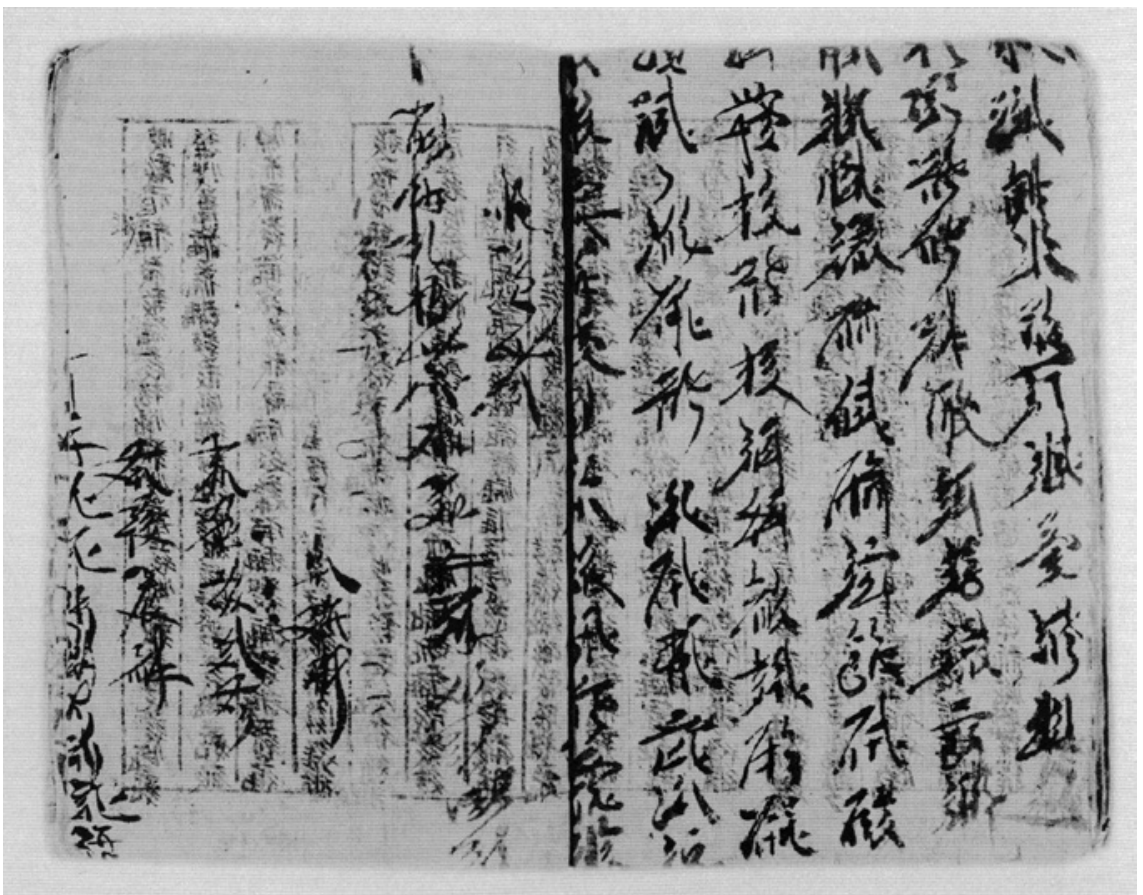

FIGURE 78 Инв. No. 5404-10: Contract of livestock sale in the Zi year of Tianqing

these prices, it is easy to tell how lucrative the trade was to export horses to the Song Dynasty.

The Laws of Heavenly Prosperity requires also that after a government-owned horse dies, the flesh is priced at 1 guan for cooked meat or 500 qian for raw meat. ${ }^{20}$ From this law, we learn the prices of not only the horse but also the horse meat.

There are also Tangut contracts of livestock transactions that list the prices of cattle and camels. ${ }^{21}$ It is impossible to underestimate the value of knowing the market prices of the four main livestock, horses, camels, cattle, and sheep, to the study of the Tangut economy.

\subsection{Accounts of Alcohol Sales and the Prices of Alcohol}

Alcohol production was a major pillar of Tangut manufacturing, partly because there was a base and tradition for brewing in the territories controlled by the

$20 \quad$ Revised Laws of Heavenly Prosperity 19, "On the Sickness of Livestock," p. 583.

21 See further discussions on the transaction of livestock in the section on livestock sale contracts in Chapter 7 . 
Tangut Empire. Of all ethnic groups and tribes living within the bounds of Western Xia, not a single of them lived without alcohol. Making alcohol was not only a matter of satiating the appetite of men, but it also added an alcohol tax to the government's income. Alcohol's importance as a commodity to both the quotidian lives of the Tanguts and in the inter-state trade of the empire is testified by the establishment of a governmental bureau for the management of alcohol production in Western Xia. The Chinese edition of the Tangut Assorted Words also mentions the departments related to liquor and fermentation. ${ }^{22}$ Although the Laws of Heavenly Prosperity does not specify the departments of alcohol management in the chapter on the five order of bureaus and commissions, it is possible to discern this from the list of staff dispatched to government offices and the several organisations devoted to alcohol-related issues, such as Storage of Liquor Ferment (qu), Bureau of Qu Sales Tax, Storage of Liquor, etc.

Yulin Cave No. 3, which dates to the Tangut period, features a realistic and vivid fresco that depicts the process of fermentation and the production of liquor in a Tangut household. Two women sit aside a flagon, an alcohol-container, and a wooden pot. One of them fans the fire from the stove whilst the other holds the ceramic bowl to let the liquor ferment. ${ }^{23}$ Experts have studied the device as portrayed in the fresco and determined that it represents a type of highly-advanced liquor distiller of the time.

It is also possible to infer liquor prices from Khara-Khoto manuscript fragments of alcohol transaction accounts. The Russian Manuscript Инв. No. 4696-8, a long scroll of 163 lines of Tangut cursive writings (with crossings) handwritten on $19.4 \times 278.8 \mathrm{~cm}$ hemp-paper, is such an account of alcohol prices. It mentions a certain "account of the quantities of rice wine from Ganzhou already sold," stating clearly that the rice-distilled alcoholic beverage concerned here came from the nearby metropolis of Ganzhou, not too far from Khara-Khoto. Each transaction is recorded in about two lines, with some exceptions occupying one line or multiple lines. Each item of transaction usually begins with the two characters 罗傲 [lew dzjwo] “one person," followed by

22 Shi Jinbo. “Xixia Hanwenben Zazi Chutan” (西夏漢文本雜字初探): “Initial Thoughts on the Chinese Miscellaneous Characters in Western Xia" in Zhongguo Minzushi Yanjiu (中國民族史研究): Studies in Chinese Ethnic History, issue 2. Beijing: Minzu College (University) of China Press, 1989.

23 Bai, Bin; Shi, Jinbo. “Mogaoku Yulinku Xixia Ziliao Gaishu” [莫高窟榆林窟西夏資料概 述]: "A Summary of Tangut Materials in the Yulin Cave of Mogao Grottoes" in Lanzhou Daxue Xuebao [蘭州大學學報]: Bulletin of Lanzhou University, issue 2, 1980. 


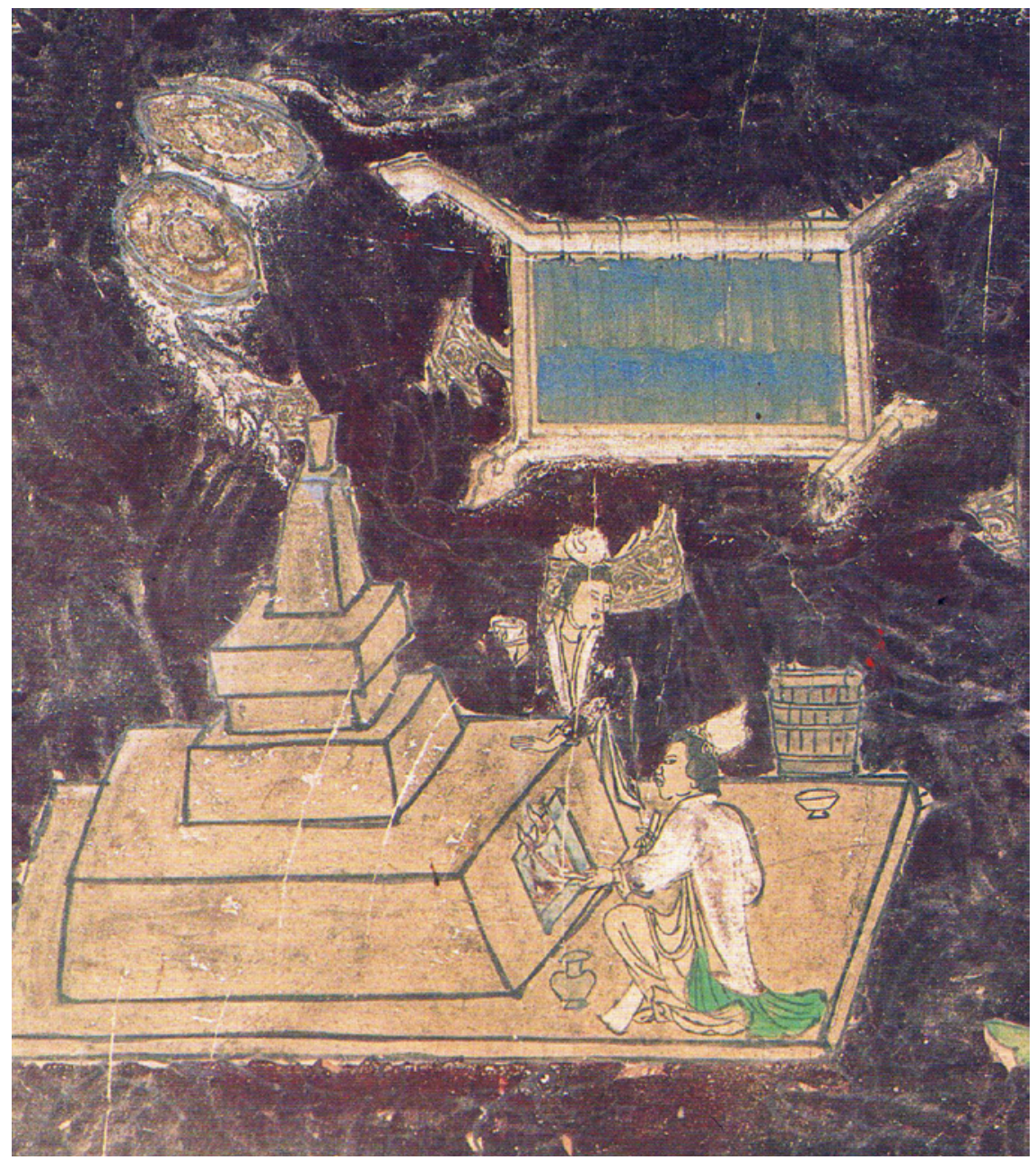

FIGURE 79 Yulin Cave No. 3: Tangut fresco depicting liquor distillation

the name of the individual(s) who purchased the liquor, then the quantities and prices of wine, usually paid in the form of grains. ${ }^{24}$

The manuscript, almost three meters in length, suffers some damages at the end. But amongst the more than 80 transactions of liquor it documents, each provides information on the persons involved, as well as the quantities and prices at which the alcohol was traded. In the account, the volume of alcohol

24 Russian Collection of Khara-Khoto Manuscripts 13, pp. 248-251. The title was confused for the previous register, "Grain Loan Contract in the Shen Year of Guangding Reign" but has since been corrected. It should instead be an account of alcohol prices. 




FIGURE 80 Инв. No. 4696-8: Account of alcohol prices (1)

is measured in the unit of dou. As for how many jin there is in a unit of dou, the document does not state clearly. The value of alcohol is not given in monetary terms but rather in the amounts of barley, which belongs to the category of assorted coarse grains, for which reason it is sometimes simply referred to as 'assorted' or 'miscellaneous.' However, it is true also that barley is an ideal material for the production of liquor.

Transactions of liquor sales could be divided into two groups. The first includes the following:

Transaction 1 records that one purchases " 1 dan liquor, at the price of 1 dan 5 dou," two guarantors;

Transaction 3: one purchased " 4 dou of liquor, at the price of 6 dou miscellaneous grains," 1 guarantor;

Transaction 4: one purchased " 4 dou of liquor, at the price of 6 dou of barley" 1 guarantor;

Transaction 5: one purchased " 4 dou of liquor, at the price of 6 dou of barley" 1 guarantor;

Transaction 6: one purchased " 4 dou of liquor, at the price of 6 dou of barley" 1 guarantor;

Transaction 7: one purchased " 1 dan of liquor, at the price of 1 dan 5 dou of barley" 1 guarantor;

Transaction 8: one purchased " 3 dou of liquor, at the price of 4 dou 5 sheng of barley" 1 guarantor; 
Transaction 9: one purchased " 2 dou of liquor, at the price of 3 dou of barley" 1 guarantor;

Transaction 10: one purchased "2 dou of liquor, at the price of 3 dou of barley" 1 guarantor;

This kind of transaction is the majority, where the price is generally 1 dou 5 sheng of miscellaneous grains per dou of liquor. Each transaction ends with a 'the connector/receiver of the document,' i.e. a 'guarantor' who shares the legal responsibility with the contractor. It seems that the greater the volume of the transaction, the more guarantors that were needed. For example, in transaction 19, Gequan and others sold 1 dan 6 dou of liquor, at the price of 2 dan 4 dou of barley, which required 4 guarantors in total.

Another kind of transaction looks like the following:

Transaction 2: one purchased " 2 dou of liquor, paid in 2 dou of miscellaneous grains at present" below: "2 dou of miscellaneous grains presently paid";

Transaction 22: one purchased " 2 dou of liquor, paid in 2 dou at present" below: "2 dou of barley presently paid";

Transaction 23: one purchased "3 dou of liquor, paid in 3 dou at present" below: " 3 dou of barley presently paid."

The price of liquor calculated from these data points is 1 dou of grains per dou of liquor, which is "paid presently" in grains. The contrast between the two types of transactions is self-evident: it turns out that if the buyer of liquor chooses to pay the liquor in full at once, then the lower price of 1 dan of grains per dou of liquor applies. If the buyer opts to buy on credit, the higher price of 1 dou 5 sheng of grains per dou of alcohol applies. In addition, the debtor would have to register for guarantors in case of default. If we look at the actual commodity prices in Western Xia at the time, the latter price came closer to the actual price of alcohol, i.e. 1 dou of grains for 1 dou of liquor. We know from before that the price of miscellaneous grains in Khara-Khoto was about 15-20 qian per sheng, from which it is possible to calculate the monetary price of alcohol to be 150-200 qian per dou of liquor.

The manuscript records a large number of names of liquor-buyers, which include not only Dangxiang Tangut names, such as Eyi, Weiming, Weiyi, Nünü, and Mazu/Maze, but also Han Chinese family names such as Zhao, Duan, Liu, Jia, Zhang, Cao, Li, etc. Of course, both the Tanguts and the Han Chinese delighted in drinking. The fact that many men exchanged grains for liquor right 
on the spot, and on large credits, testifies to the pervasive drinking culture in Western Xia at the time.

In addition, four pages of alcohol accounts have been found in Manuscript Инв. No. 1366-6 to 9. All of them are fragments handwritten on hemp paper in the cursive style, not without edits and erasures. The $13.6 \times 12.5 \mathrm{~cm}$ manuscript Инв. No. 1366-6 contains five lines of Tangut and an additional seven lines in a smaller font. The $13.6 \times 12.5 \mathrm{~cm}$ Инв. No. 1366-7 has eight lines of large Tangut characters and 5 lines of smaller characters. The $18.7 \times 29.3 \mathrm{~cm}$ Инв. No. 1366-8 features 14 lines of Tangut. Finally, the $25.4 \times 25.2 \mathrm{~cm}$ Инв. No. $1366-9$ has 15 and 16 lines of Tangut, with prints and signatures. At the beginning of each transaction is the name of the liquor buyer, though some of these names in the fragments are missing. ${ }^{25}$

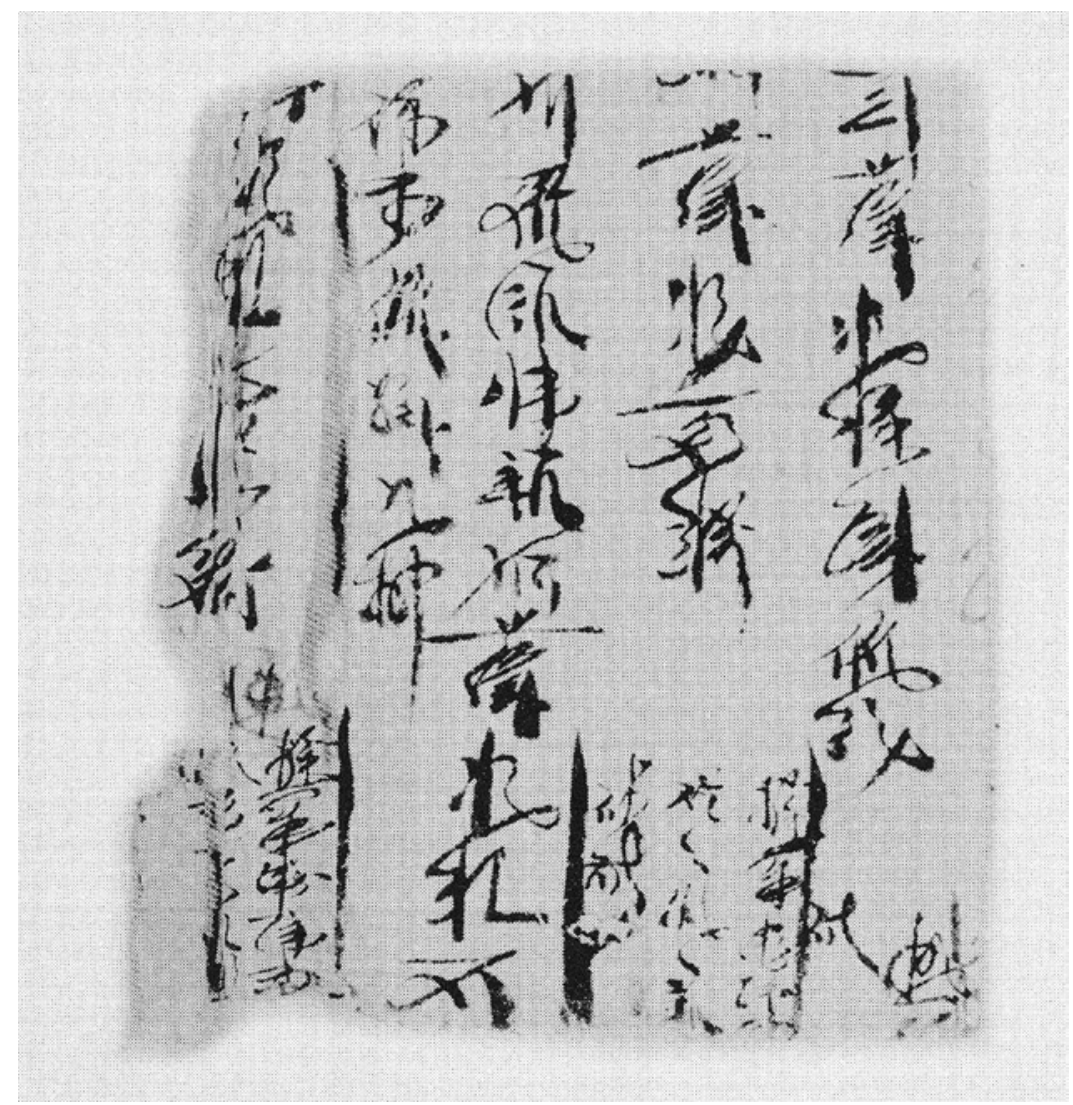

FIGURE 81 Инв. No. 1366-6: Account of alcohol prices

25 Russian Collection of Khara-Khoto Manuscripts 12, pp. 241-243. 


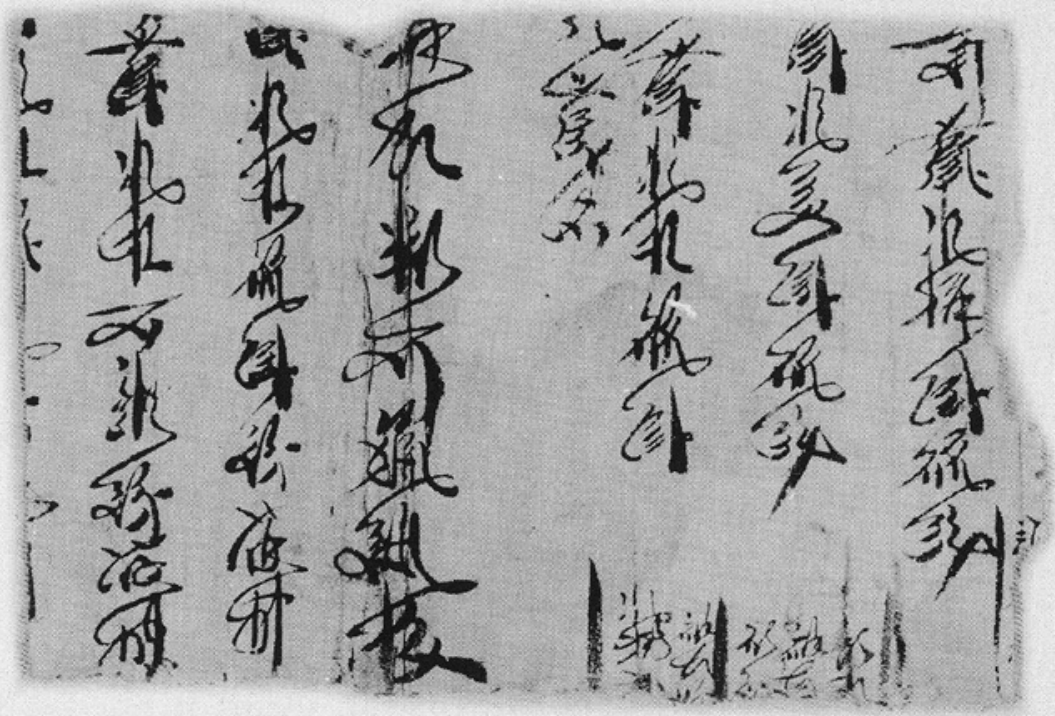

FIGURE 82 Инв. No. 1366-7: Account of alcohol prices

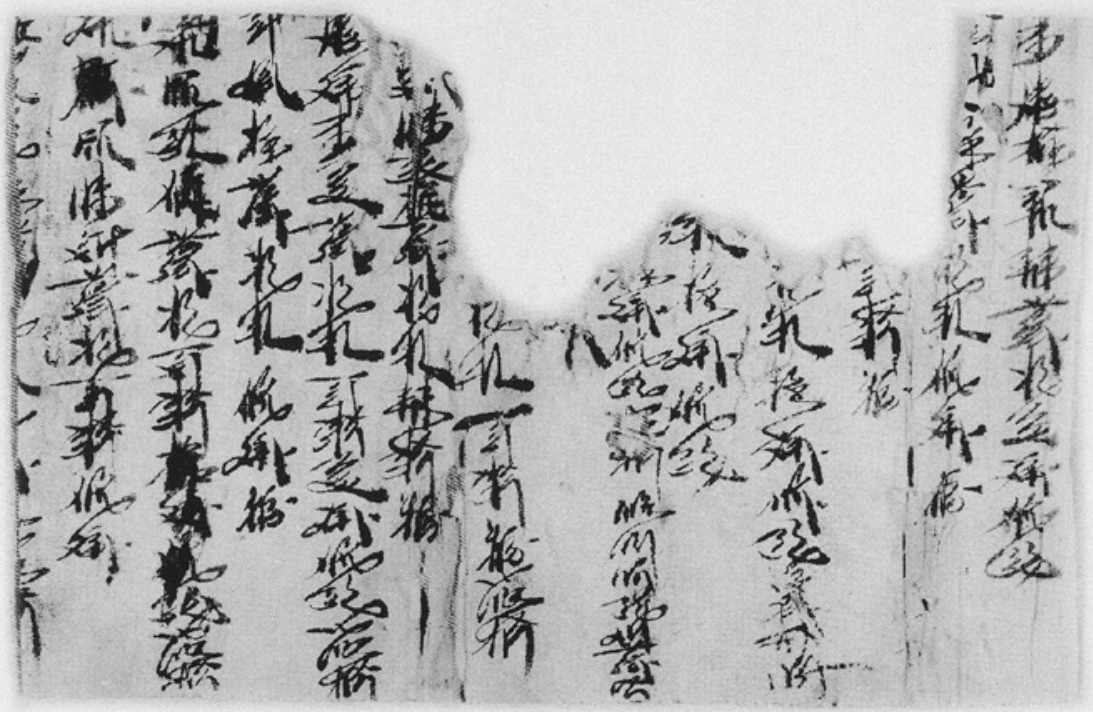

FIGURE 83 Инв. No. 1366-8: Account of alcohol prices 


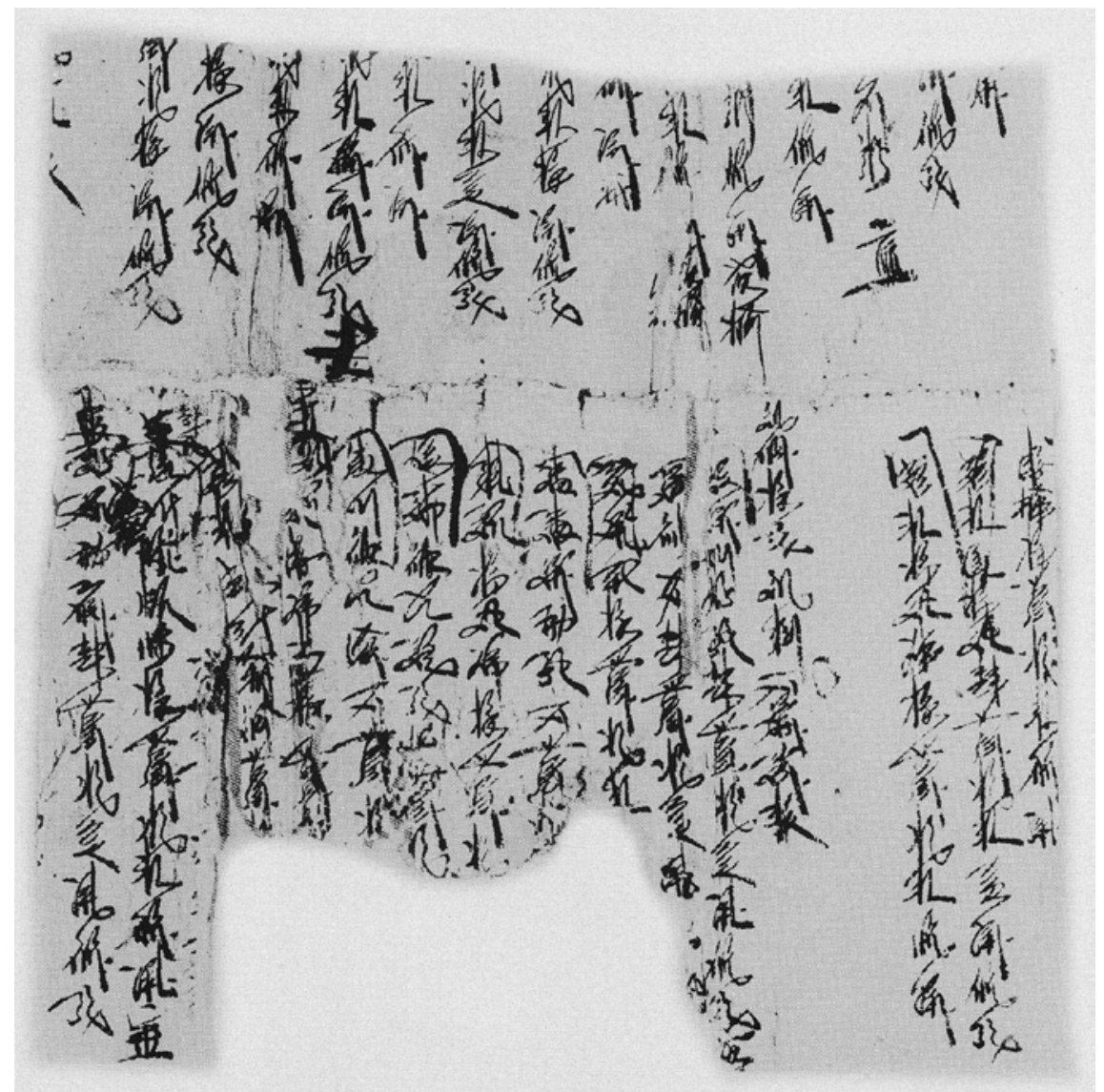

FIGURE 84 Инв. No. 1366-9: Account of alcohol prices

The following is a literal translation of the first three lines in the Russian Manuscript Инв. No. 1366-6 (account of alcohol prices):

... One dou of liquor, two hundred fifty

... four dou of liquor, one guan

... "Dog? Mount" et al. Four dou at the liquor price of one guan

The following is a literal translation of the Russian Manuscript Инв. No. 1366-7 (account of alcohol prices):

... one dou of liquor, two hundred fifty

... three dou of liquor, seven hundred fifty

... two dou of liquor, price five hundred 
... second day, one pot sold

... dou liquor, price 500 qian presently paid

... dou liquor, price 1 guan presently paid

On the Russian Manuscript Инв. No. 1366-8 (account of alcohol prices), the top sections of lines $3-8$ remain only in fragments. The following is a literal translation of lines 1, 2, 9 and afterwards:

... zi aba (消栟烽) et al., 3 dou of liquor, $75^{\circ}$

... 2 dou of liquor, price 500 qian

$\cdots$

... "mount" (... 㥪), 12 dou of liquor, price 3 guan

... "the lucky one" (... 娣娇尚), 7 dou of liquor, price 1 guan 750 qian paid

... “ joy, you” (... 哆徽), 2 dou of liquor, price 500 qian

... "prosperous" (羓), 5 dou of liquor, 1 guan 250 qian paid

... “manure, mount” (版㥪), 6 dou of liquor, price 1 guan 500

...

The two fragment pages of the Russian Manuscript Инв. No. 1366-9 (account of alcohol prices) feature some similar transactions. Line 4 of the second section also mentions "Sep. 29th, a pot of liquor sold." It is not difficult to see that all such aforementioned purchases are transacted in cash at the price of 250 qian per dou, slightly higher than the retail price of alcohol in terms of grains. The unit price of liquor per dou exceeds the unit price of miscellaneous grains (per $d o u$ ) and reaches the price of wheat (per dou). It speaks to the profitability of the alcohol industries.

Consistent with Tangut economic policies elsewhere, the Western Xia imperial government imposed special regulations on the sale of alcohol, especially liquor ferment ( $q u$, or jiuqu), a material essential to the fermentation and manufacture of alcohol. The production of liquor ferment, or liquor-starter, is subject to total control and comprehensive supervision of state agencies. The Laws of Heavenly Prosperity has a special chapter "On miscellaneous affairs related to the Liquor Ferment" which stipulates for the management of $q u$ and alcohol in multiple statements, ruling above all that no private enterprise be allowed to produce liquor ferment:

The many are notallowed to produce liquor ferments. In case this law is violated, it is necessary for officials to measure the weight of privately-made $q u$ throughout this period in terms of jin. If the illegally-made liquor 
ferment is within one string, let those with criminal intention be punished with thirteen strokes, and all accomplices, ten strokes ... between eight and ten strings, let those with criminal intention be imprisoned for four years, and all accomplices, three years ... above twenty strings, let those with criminal intentions be sentenced to life imprisonment, and all accomplices, imprisonment for twelve years; in case the buyers of these liquor ferments are aware of their illegality, they should suffer penalty at one level below the accomplices; if they are not aware of the crimes, let them not suffer punishment. ${ }^{26}$

The sale of liquor ferments is an exclusive business of the government. By purchasing them from official sources, owners of alcohol factories contributed taxes to the finances of the empire. As expected, the Laws of Heavenly Prosperity regulated the price of liquor starters: "Where liquor starters are sold, 2 dou of barley and wheat count toward 15 jin, and each jin [of qu] should be sold at the price of 300 qian." 27 We know therefore the extortionate price of liquor starters at the time to be 4 guan 500 qian per dou/15 jin of qu.

\subsection{Accounts of Other Commodities and Their Prices}

\subsubsection{Account of Silk Sales and Silk Prices}

The early phase of Western Xia's path to imperial glory is marked by frequent wars with the Song empire. According to the narrative of Chinese archives, "the enemies (TN: refers to the Tanguts) are likewise exhausted, then deprived of resting time for farming and pasturing, with the result that amongst the barbarians (TN: again, the Tanguts, in particular), the cost of cloth reaches exorbitant prices in the tens of thousands." ${ }^{28}$ It credibly shows that in the most difficult time of war in early Tangut history, when cash was destitute and resource was scarce, the unit price of cloth per $p i$ was as high as more than ten guan.

Amongst the Khara-Khoto manuscripts in Russia is the Инв. No. $385^{8-1}$, a fragment account of commodity prices, handwritten on a $33.8 \times 31 \mathrm{~cm}$ pasted hemp paper used originally as a layering page to a book cover, with 14 lines of prices and other information written in the Tangut cursive. ${ }^{29}$

26 Revised Laws of Heavenly Prosperity 18, "On the Miscellaneous Qu," pp. 565-566.

27 Revised Laws of Heavenly Prosperity 18, "On the Opening and Closing of Salt Pond," p. 566.

28 Su Shi, Complete Works of Su Dongpo, Bk. 88, Inscription for Sir Zhang Wending (張文定 公墓志銘).

29 Russian Collection of Khara-Khoto Manuscripts 13, p. 173. 


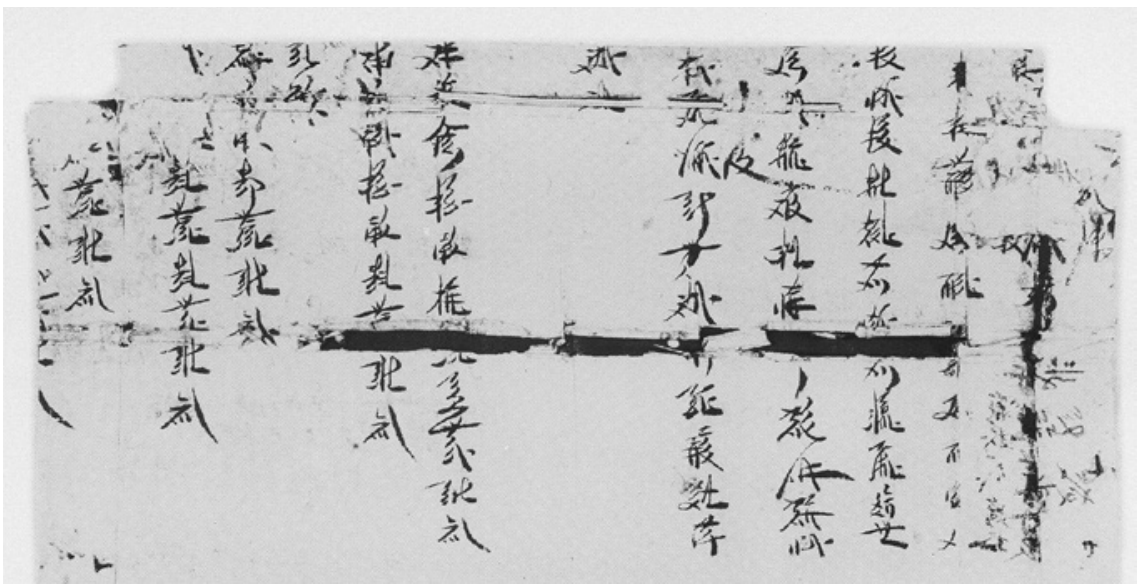

FIGURE 85 Инв. No. $3^{8} 5^{8-1}$ (top section): Account of commodity prices

In this manuscript, line 6 documents "silk, 1 chi 2 dou 7 sheng, several miscellaneous" followed by the account of silk and cloth prices, despite missing characters in the names of the goods and materials. At the price of assorted grains at 150-20o qian per dou, it is possible to narrow down the price of silk per chi at around 400-540 qian. At the time, each pi of silk was measured at about 4 zhang, or $40 \mathrm{chi}$. If so, it is possible to infer the price of silk per pi to be somewhere around 16-21 guan, which is obviously too expensive for the impoverished plebeian families of Western Xia.

The price of silk in the Song Dynasty varied greatly from the early to later periods. In Northern Song, silk was relatively affordable, being around 5oo wen/ qian to 1 guan per $p i$. In Southern Song, however, silk prices soared higher to 2-8 guan per $p i .^{30}$ By comparison, however, the price of silk in Tangut markets far exceeded that in the Central Plains even at the time of Southern Song.

Another relevant document in the Khara-Khoto corpus of economic records is the fragment manuscript Инв. No. 625, account of transaction prices. The text records time and dates, as well as the titles and prices of silk. However, due to non-ideal conditions of preservation, too few legible data remain for us to calculate the actual prices.

\subsubsection{Account of Butter Sales}

The Khara-Khoto Russian Manuscript Инв. No. 5808 is a rare bilingual account of butter sales, in both Tangut and Chinese. It is likewise handwritten on an

30 Qi, Xia. Zhongguo Jingji Tongshi [中國經濟通史]: Complete History of the Chinese Economy, vol. II, Economic Daily Press (經濟日報社), 1999, pp. 1242-1243. 


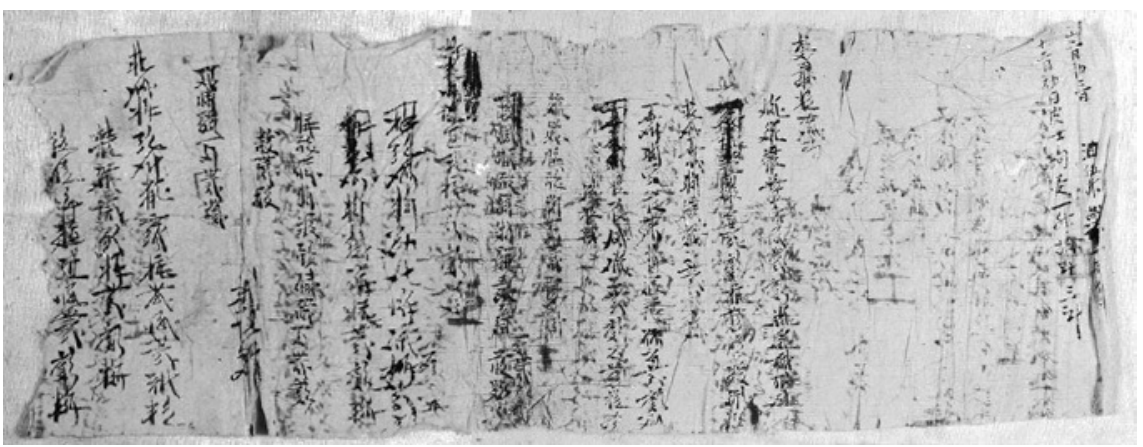

FIgURE 86 Инв. No. 5808: Account of butter sales

$18.5 \times 51.6 \mathrm{~cm}$ fragment hemp paper, which begins with two lines of Chinese and 19 lines of Tangut in cursive, featuring also prints, signatures, and crossings. ${ }^{31}$

On the right are shown the following two vertical lines in Chinese characters:

Twelfth month, the third day, oil (butter) five jin

Twelfth month, first day ... one sheng ... three dou. ${ }^{32}$

In the distance of about five to six lines, there are 19 lines in Tangut characters, which are not altogether perfectly legible. The following is a selective translation of whatever still remains identifiable.

The first line provides the title, which literally translates as "oil, milk (TN: butter), sale, list" i.e. "account of butter sales." As for the identities of the parties and departments involved, there is little to no information. The document then proceeds to list the sales of butter by individual transactions, some of which begin with time, while others with the names of the customers. The first line, for example, records that "Weiyi Bore? (㷋恉澱荻?) 5 sheng of but-

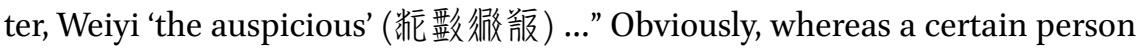
named Weiyi Bore? purchased 5 sheng of butter, we are not fortunate enough to know how much the other Weiyi bought from the same shop. Line 4 features a curious expression, "Twelfth month, on the fifteenth day, the 'many burdens' one sheng of butter, distributed"-it does not appear that the "many burdens" sounds like a typical Tangut name, but rather that a group of merchants with a team of burden-bearing camels came to purchase butter together. This hypothesis is further corroborated by the reappearance of butter-buying 'burdens' in

$31 \quad$ Russian Collection of Khara-Khoto Manuscripts 14, p. $5^{2}$.

32 TN: Chinese characters as shown on the manuscript: “十二月初三日 油伍斤” and “十二 月初日皮士?? 一升，胡?三斗.” 
line 8. Lines 11 and 12 narrate: "on the twenty-fourth day, Zhang Laofangquan (预父拼稓), one and a half sheng of butter" and “on the twenty-fourth day, Shi Jiao, two sheng of butter, purchased," respectively.

Especially worthy of notice are lines 13 and 14: "On the twenty-fifth day, Cao

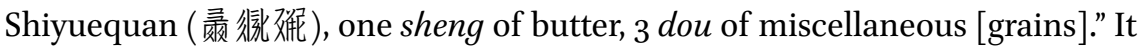
is uncertain if Cao paid for 1 sheng of butter with 3 dou of miscellaneous grains. Should this be the case, the butter-to-grain price ratio would appear higher than expected.

Line 16 narrates that "Eshansheng one sheng holds," that is, he retrieves, or supposedly purchases 1 sheng of butter.

Line 17 tells the story that "in the final month, on the twenty-sixth day, the quantity of 2 dou 5 sheng is sold." This statement is written unindented, at a position on the page higher than other lines. The format signifies that the number hereby indicated is the total sum of the multiple transactions in the several following lines, hence the relatively large number of 2 dou and 5 sheng. The next line writes, "the House of Dog-posting Craft Station, two sheng of butter, purchased." It is decidedly unclear what sort of institution this dog-relaying station could have been. Finally, the person named Yehe "the overjoyed at heart"

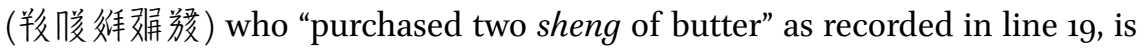
evidently a man of Tangut ethnicity.

In general, Tangut accounts of butter sales are rare manuscripts. Despite the evident incompleteness of information, the texts related and translated above do provide scholars with valuable sources on the economic lives and activities of the Tangut communities in Khara-Khoto. The fact that a merchant daily preoccupied with selling butter records his transactions so formally and meticulously testifies to the detail-oriented character of the sales management of common commodities, as well as the systematic documentation, if not regulation, of commercial activities at the local level.

\subsubsection{Other Accounts of Transactions}

With pasturing and livestock-raising being the most developed sector of the Tangut economy, it is no surprise that the warmth-keeping and humiditychecking fur products constituted both a major daily necessity and a key source of export for the Tanguts. Camels, horses, cattle, sheep, jade, fur carpets, and liquorice (glycyrrhiza uralensis) were the local specialties in Tangut trade with the Song Dynasty. ${ }^{33}$ There is, for example, an account of fur carpet prices in the Russian collection of Khara-Khoto manuscripts. The Инв. No. 1219-2 "account of transaction prices" are two fragments patched as one document, 


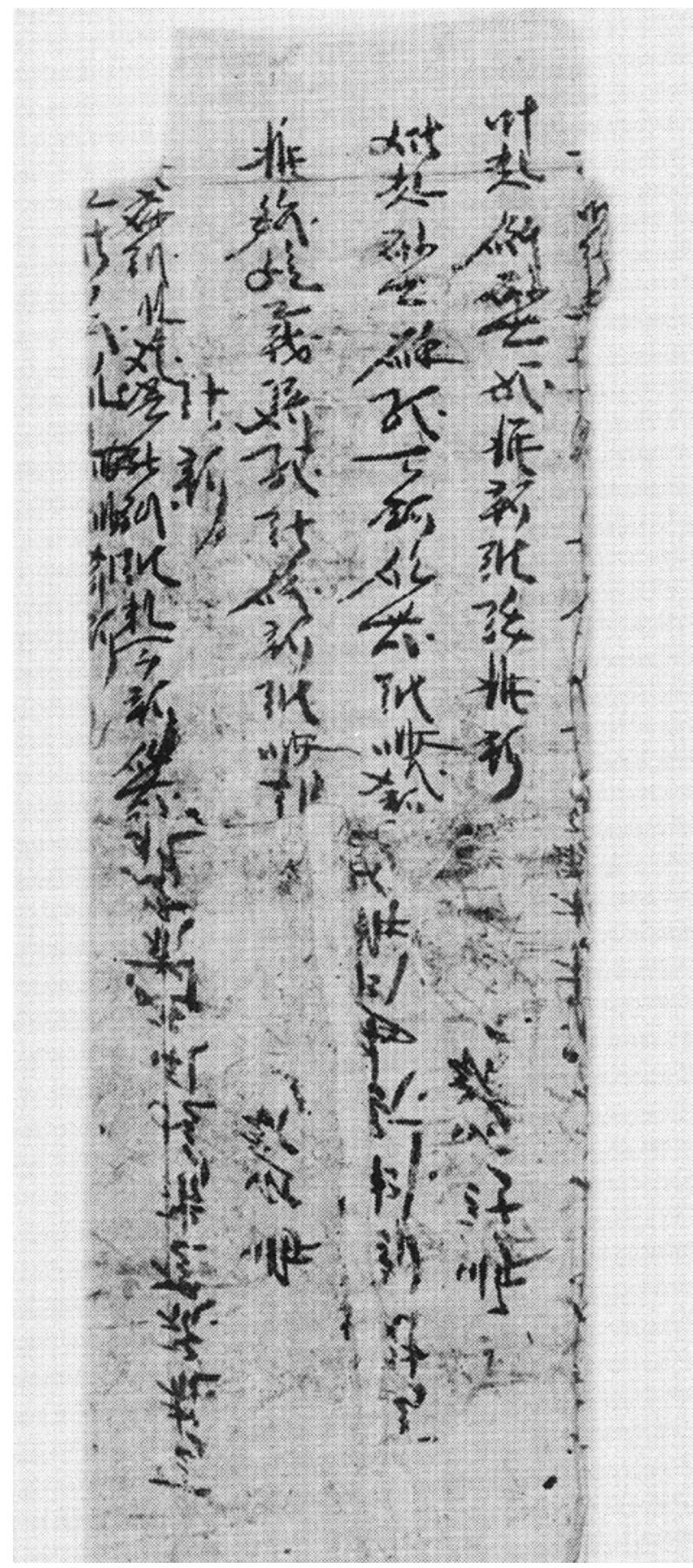

FIGURE 87 Инв. No. 1219-2: Account of prices 
handwritten on a $36.9 \times 13.4$ piece of hemp paper, with seven lines of Tangut in the cursive style. ${ }^{34}$

The prices of fur carpets can be found in the first and second lines of the text. The Tangut character for fur carpet is 攽 [lju]. The following is a translation of the twelfth line of the document: "Fan carpet, 2 dan each, total count 12 dan"; " 6 white fur carpet, 1 dan 5 dou each, total count 9 dan." Note with care that the 'Fan' in "Fan fur carpet" is not the character that refers to the Dangxiang Tangut 仮 [mji], but the Tangut character 修 [xiwa ] that is often borrowed to translate Sanskrit. It is possible that it may be referring to 'Tangut' in this case, after all. Either way, we know the prices of the two types of carpet: a roll of Fan carpet costs 2 dan of grains each and a roll of the white fur carpet is 1 dan 5 dou each.

Some transaction accounts miss the critical information on the very types of goods that are being traded. Nonetheless, it is possible to calculate the prices of these unidentified goods. One example is the $23.5 \times 55.8 \mathrm{~cm}$ manuscript fragment Инв. No. 7885, an account of transaction prices handwritten on a piece of hemp paper, with 20 lines of Tangut in cursive and formal prints. ${ }^{35}$

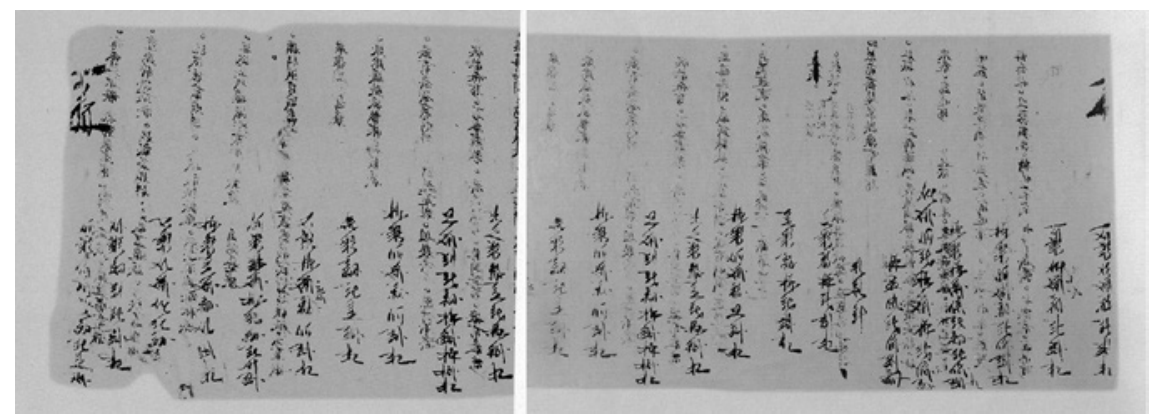

FIGURE 88 Инв. No. 7885: Account of transaction prices

The following is a literal translation:

1 guan 600 mace, 10 jin price

1 guan 600 mace, 10 jin price

2 guan 400 mace 15 jin price

34 Russian Collection of Khara-Khoto Manuscripts 14, p. 52.

35 Russian Collection of Khara-Khoto Manuscripts 14, pp. 199, 200. 
2 guan 215 mace 15 jin price

642 (guan) 125 mace

2055jin?

price? is

7 guan 20 jin price

7 guan 20 jin price

2 guan 400 mace 8 jin price

18 guan mace 72 jin price

830 mace 2 jin 2 liang price

2 guan 400 mace 4 jin price

5 guan mace 17 jin price

Some of the items above are single transaction accounts. Others, such as lines 5,6 , and 7 , are summary accounts. The following is a statistical analysis of the price (per jin) in these transactions:

снARт 10 Инв. No. 7885: Account of transaction prices (statistics on the first 4 transactions)

\begin{tabular}{llll}
\hline & Purchase Prices & Quantity $($ jin $)$ & Price (per jin) \\
\hline Transaction 1 & 1 guan 6oo qian & 10 & 160 \\
Transaction 2 & 1 guan 600 qian & 10 & 160 \\
Transaction 3 & 2 guan 400 qian & 15 & 160 \\
Transaction 4 & 2 guan 250 qian & 15 & 150 \\
\hline
\end{tabular}

The unit price is easily derived from the division of purchase prices by the quantity purchased. The first four listings seem to fit together in one section. The last seven may be grouped together, separately. Lamentably, the condition of the manuscript leaves us no viable evidence to infer what type of good these transactions concern. The unit price of the first four transactions ranges between 150 and 160 mace per jin. The price is higher in the last seven transactions, around 300 mace per jin. Only in the sixth transaction is the price as high as 600 mace per jin. Between the two accounts, there is a line of summary statistics. Readers may resupply the currency unit "guan" after the first number: total sum 642 (guan) and 125 mace, for 2055 jin, whereby the unit price is 316 mace per jin, not too far off from the price derived from the last seven transactions. It is possible, therefore, that this number records the sum of the next seven transactions. 
It is evident from the transactions of alcohol, livestock, and silk, that at least in some regions, the Tanguts exchanged more often than not in kinds, rather than in cash. One might think that it speaks to the underdeveloped nature of the Tangut commodity economy. Still, another factor to consider is the scarcity of copper and iron mines in Western Xia, aggravated by the policy of iron and copper embargo from the Song and Jin Dynasties. Therefore, in the tumultuous times toward the end of Tangut power, exchange in kinds prevailed in the market.

The Tangut text, Golden Fragments states that "whilst the mixed conditions bemuse, the prices clearly vary. ${ }^{\prime 36}$ In other words, the prices vary according to the qualities of the goods traded in Tangut markets.

The commodity prices presented and analysed above are generally equivalent to contemporaneous prices in the Song Dynasty. The closeness of their prices has a lot to do with their neighbouring status, similarity in both modes of production and living conditions, and the circulation of Song cash across imperial boundaries.

Tangut commodities are plentiful and diverse. The prices analysed in this chapter are only the tip of an iceberg. From the prices of these important goods and critical commodities, it is possible to understand the actual living conditions of the Tangut people.

Western Xia relies on taxation to support the operation of its political machine and bureaucratic offices, pay government employees, build its army and feed the soldiers, and sustain cultural and religious developments. Apart from agricultural taxes, commercial tax is a large source of income. The Golden

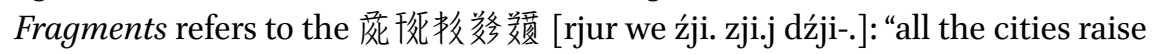
transaction tax." The "commercial tax" or "transaction tax" literally refers to "sales tax," the levy on the selling of a commodity. This reference speaks to the fact that the Tanguts raised transaction taxes in the commercial markets of major cities. ${ }^{37}$

$36 \quad$ Nie Hongyin and Shi Jinbo, 1995 .

37 Ibid. 
The Laws of Heavenly Prosperity (18) features a section on "Raising transac-

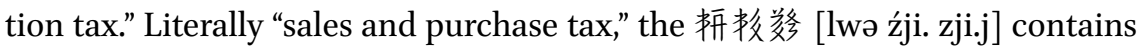
the following 19 items: ${ }^{38}$

\section{Hiding transaction tax}

Method of tax payment in order when opening a new business

Opening business on tax exemption

Tax across various regions

Requested tax on litigation

Rules on government purchase of certain goods

Tax on livestock on ships

Omission of tax at certain selling prices.

Extraterritorial tax exemption

Trade with enemy envoys

Merchants from the borders visit the Capital

Tax exemption for reselling

Forced exchange of livestock

Obtaining the goods when the money equals the value of the pawned goods

Omission of tax concerning a matchmaker and an abandoned wife Inaccurate reporting to seek tax exemption

Coordination when the authority over tax is not explicitly mentioned Receiving tax document at specified times

Government review of transactions ${ }^{39}$

These legislations testify to the historical presence of shops and markets in Western Xia. Opening a new business is taxable, but the tax rates vary from one region to another. Occasionally, it is possible to file for tax exemption.

Both sales and purchases are taxed in Western Xia. The rates and amounts of taxes are not recorded in traditional historical sources, either in Tangut or in Chinese. Due to missing information in legislations on transaction taxes in the Laws of Heavenly Prosperity, little evidence is there for historians to work out the tax rate. Some special statements in the Laws of Heavenly Prosperity offer us a glimpse at certain types of taxes, such as the tax on salt sales:

38 TN: The following is a list of headings in the table of contents. The actual content is missing, so wherever the meaning of the title itself is unclear, I have taken the liberty to either frame the translation intentionally in a broad way, or to interpret as seems most sensible.

Revised Laws of Heavenly Prosperity, "Part II of the Titles," pp. 96-97. 
Concerning all salt dealers, the salt from the $W u$ Pond should be sold at the price of a hundred and fifty maces per dou; for salt extracted from other salt ponds, the price is a hundred maces per dou. Let all taxes be levied and leave no tax evaded. In case of a violation of law, the amount of taxes evaded is to be calculated, and the concerned individuals will be prosecuted on the charge of theft. ${ }^{40}$

Here, the tax is calculated in terms of cash currency rather than grains. The salt reservoir is overseen by the House of Salt Tax. The head of this political office and the "Patrolling Supervisory Officer" are both in charge of guarding the salt resources of Western Xia. ${ }^{41}$

A large quantity of transaction tax accounts has been discovered in the city of Khara-Khoto. Although most are disjointed leaves and manuscript fragments, these documents show that practically all transactions in Western Xia were liable for taxation. The amounts of taxes vary according to the quantity sold or purchased as well as the types of commodities being traded. These primary materials add significantly to the historians' understanding of general Tangut commerce and transaction taxes, in particular.

Although largely incomplete, these accounts of transaction taxes reveal the basic format of transaction tax records in Khara-Khoto. In most cases, each line is devoted to one transaction. In special cases where the volume is large and the information convoluted, one transaction may be written in two lines. Each transaction record begins with the name of the seller, followed by the goods concerned, sometimes also the quantity of the products sold, and finally the sum of taxes to be paid. In all existing cases known to Tangutologists today, the payments are in kinds-mostly grains - rather than in cash. Oftentimes, buyers purchase a good by either barley or wheat. Of course, the transaction tax rate varies according to the different types of goods.

The commodities traded in these transaction accounts are quite diverse, from cloth to sheep, horse, and cattle. Others purchase gold and even human beings. Some of the goods remain unidentified. For example, in the manuscript Инв. No. 4790-2, it is unclear what is being purchased here. All we know is the relatively low tax rate: 1 sheng of wheat. Some documents only record the taxes but then leave the types and quantities of commodities unmentioned.

$40 \quad$ Revised Laws of Heavenly Prosperity 18, "On the Opening and Closing of Salt Reservoirs," p. 566.

41 Revised Laws of Heavenly Prosperity 17, "On the Transfer and Transportation between Bureaus," p. 535 . 
The manuscript Инв. No. $479 \mathrm{o}$ is an account of transaction taxes composed of four leaf fragments, all of which are handwritten on hemp papers in cursive. The manuscripts Инв. No. 479o-2 and Инв. No. 479о-3 are both $19.3 \times 11.2 \mathrm{~cm}$ in size, with five lines of Tangut each. The Инв. No. 4790-4, likewise $19.3 \times 11.2 \mathrm{~cm}$ in size with five lines of Tangut, features a red seal. The manuscript Инв. No. $4790-5$ of the same size has four lines of Tangut, and a red seal. ${ }^{42}$

The four manuscript fragments follow the same format of recording a transaction on each line. In spite of missing information on the quantity of commodities sold and purchased and on many goods that remain unidentifiable and untranslated, it is possible to survey the bits and pieces of these transaction tax records that can be deciphered and interpreted.

The five lines in the manuscript Инв. No. 4790-3, an account of transaction taxes, record the taxes paid for the purchase of commodities. The identity of the goods remains impenetrable and mysterious, but the amounts of taxes in the first four lines are clearly legible: wheat 1 sheng, 1 dou 5 sheng, wheat 1 dou, wheat 1 sheng.

Lines $2-3$ in the manuscript Инв. No. 479o-3, an account of transaction taxes, mentions that "Gao 'the Lucky Dog' for the purchase of human being(s), taxes 1 dan 3 dou and ... white cloth, paid"; line 4 in the same text speaks of "Gao??Mount purchases camel(s), tax wheat 3 dou." Line 2 in the manuscript Инв. No. 4790-4, also an account of transaction taxes, refers to a certain "??Kind Mount, purchases cloth, tax 1 sheng." There is no doubt that the socio economic phenomenon of human transaction took place in Western Xia, wherein a buyer has to shoulder the burden of transaction taxes. ${ }^{43}$ From the records of many transactions that remain legible and have been studied, it is also clear that human transactions are the most taxed. The camels come next, followed by fine silk.

The manuscript Инв. No. 479o-4 account of transaction taxes features a square seal in the middle, with four Tangut characters in the seal script. Judging on the basis of their shape and content, it is possible that the four characters

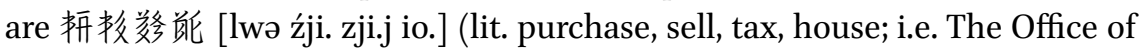
Transaction Tax). A larger and rectangular seal of the Office of Transaction has been identified in a land sale contract. The right half of the same seal is found in the manuscript Инв. No. 4790-5, another account of transaction taxes.

The account of transaction taxes Инв. No. 5943 is also composed of four fragment leaves, all written in the cursive style. The $20.5 \times 11.3 \mathrm{~cm}$ manuscript Инв.

42 Russian Collection of Khara-Khoto Manuscripts 14, pp. 288-289.

43 For more discussions on human transactions, see later sections on human transaction contracts. 


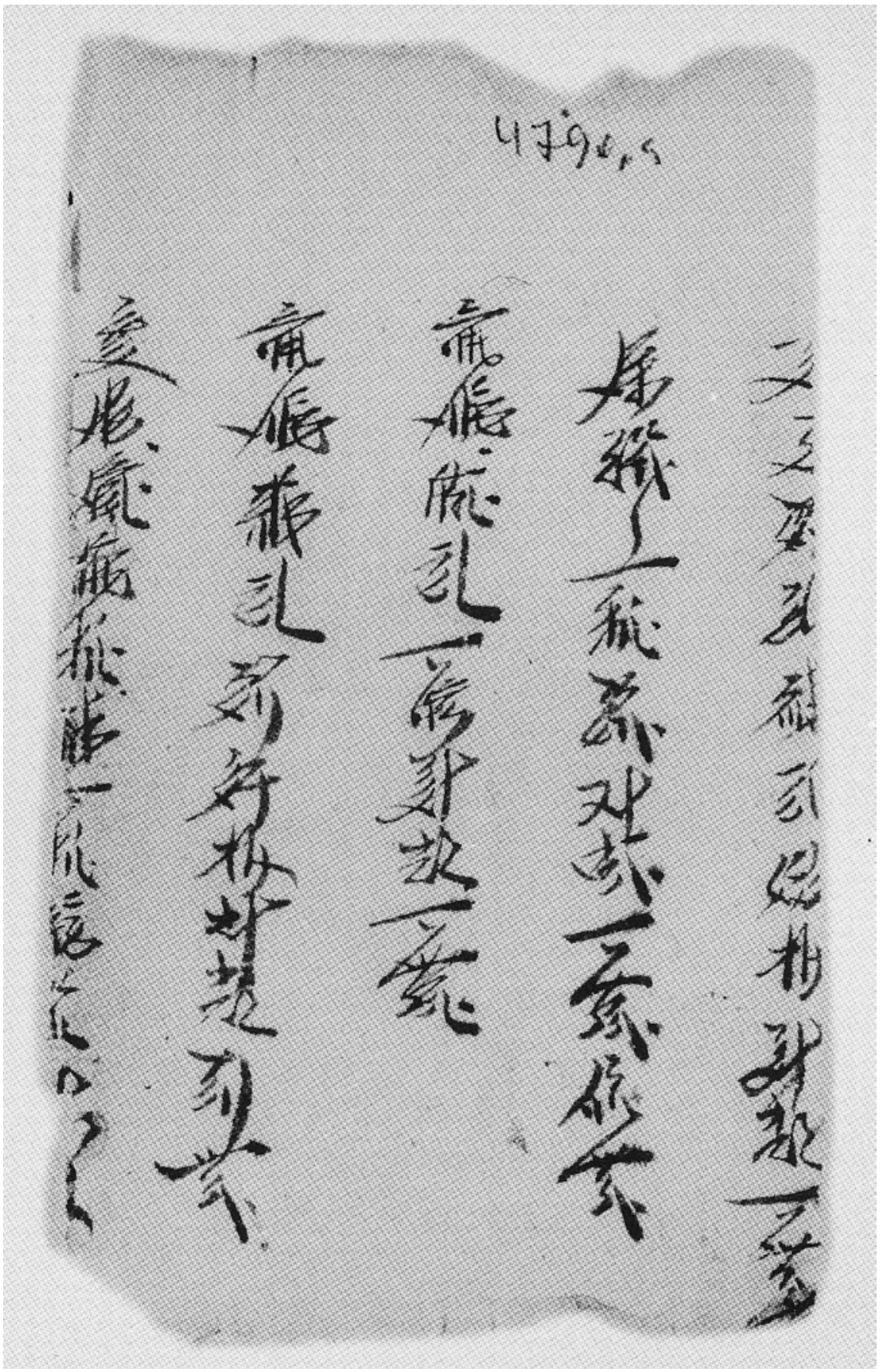

FIGURE 89 Инв. No. 479o-2: Account of transaction taxes 


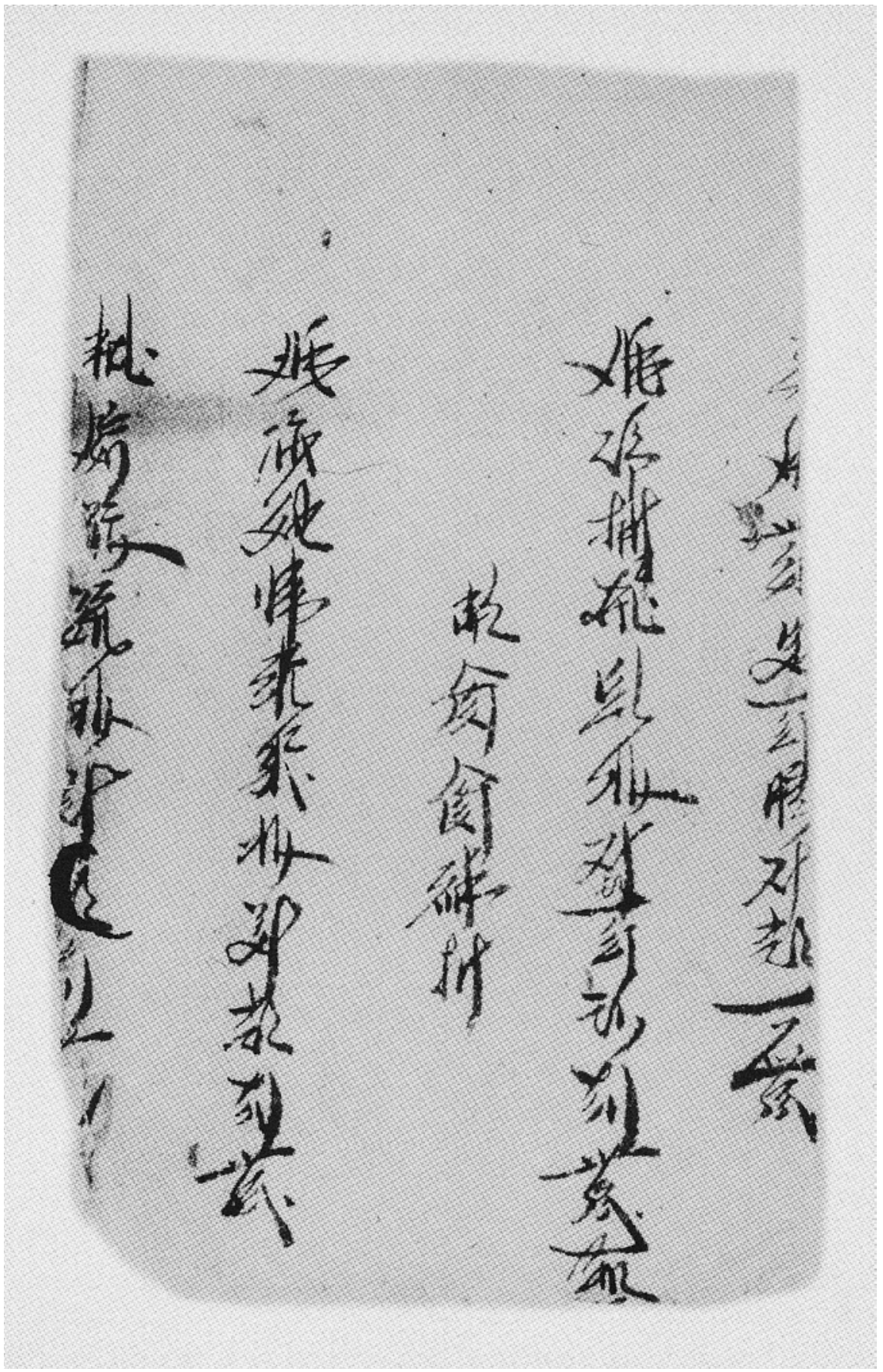

FIGURE 90 Инв. No. 479o-3: Account of transaction taxes 


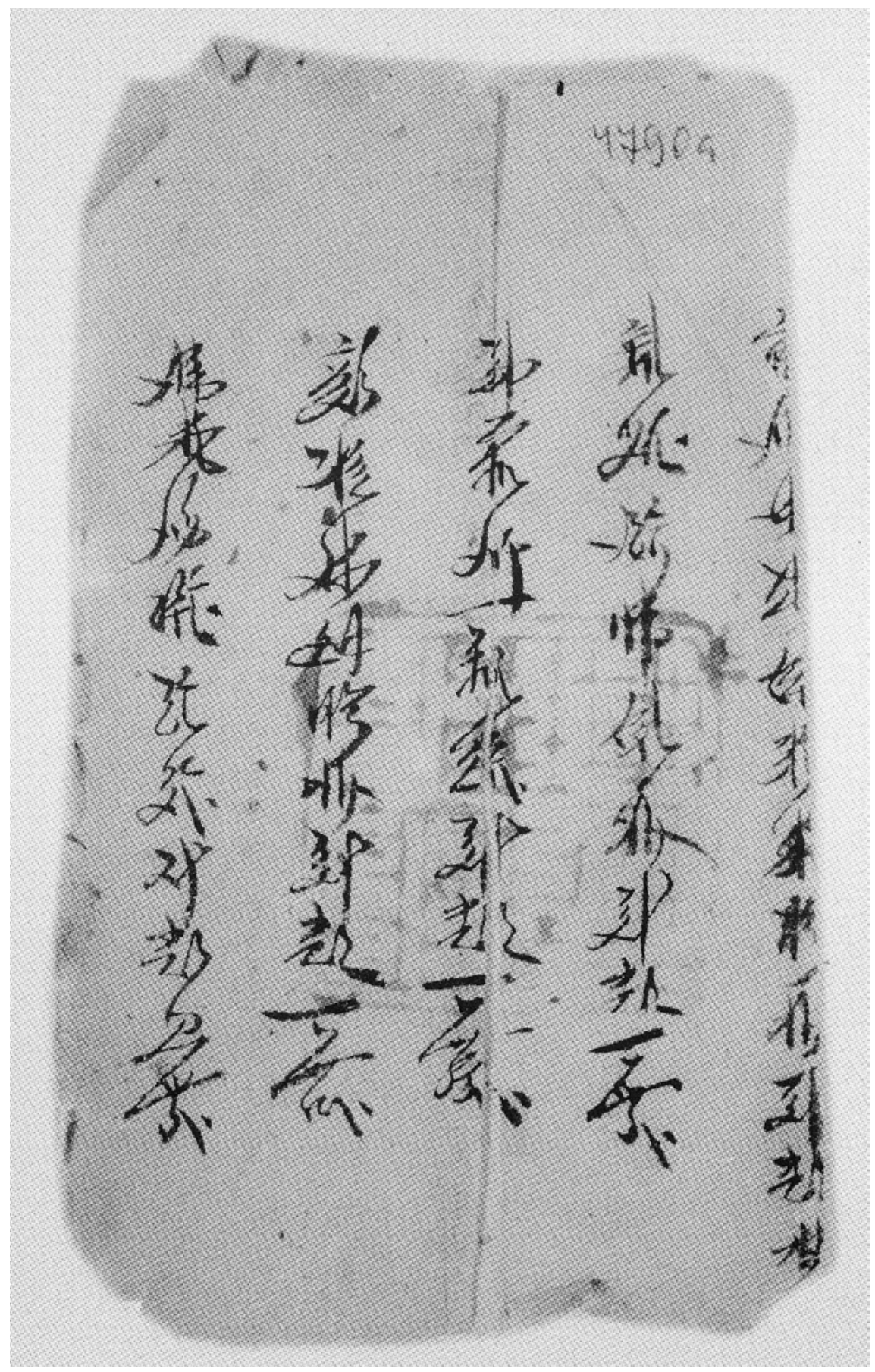

FIgURE 91 Инв. No. 479o-4: Account of transaction taxes 


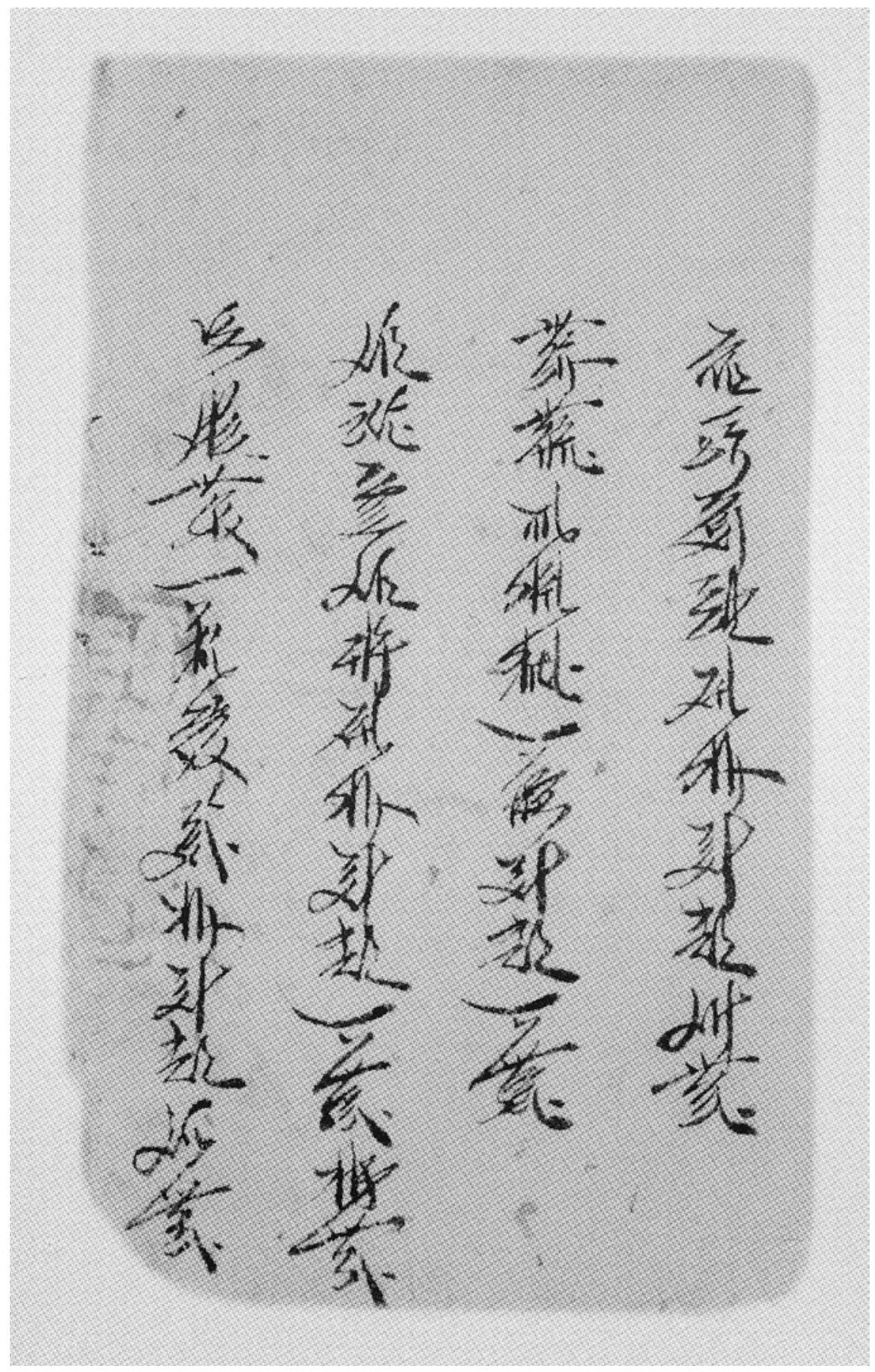

FIgURE 92 Инв. No. 479o-5: Account of transaction taxes 
No. 5943-1 contains six lines of Tangut; the Инв. No. 5943-2 and Инв. No. 5943-3 are of the same size and each has five lines. The manuscript Инв. No. 5943-4, also $20.5 \times 11.3 \mathrm{~cm}$, has four lines of Tangut, a seal, stamp, and signature. ${ }^{44}$

In line 4 of the manuscript Инв. No. 5943-1, it is mentioned that "Langluo Xian?nu pays the land purchase tax in the amount of barley 2 dan 4 dou"; Line 2 of the manuscript Инв. No. 5943-3 records that "Weiming Lijiade pays wheat 2 dou 4 sheng in tax for the purchase of gold"; Near the end of manuscript Инв. No. 5943-4, an account of transaction taxes, there are three large characters: 预 [kju], 瓶 [khio] (skilful, adept), and 躷 [kwa ]. The first and third are common words used for transliteration purposes. Altogether, they may be translated to "tax-collector."

The documents Инв. No. 6377-13 and 14, both manuscript fragments written in the Tangut cursive, are important accounts of transaction taxes. The Инв. No. $6377^{-13}$ is $19.8 \times 36.5 \mathrm{~cm}$ in size, with 21 lines of Tangut, the red seal of the Tangut House of Purchase and Sell Taxes, print, and signature; the $19.8 \times 23.2 \mathrm{~cm}$ manuscript Инв. No. $6377-14$ features 14 lines of Tangut with print and signature. ${ }^{46}$

The manuscript Инв. No. 6377-13 suffers a range of damages and losses of characters, including at the beginning and the end, and with the first characters of a few lines; lines 1 and 2 are also not clear and barely legible. What remains of lines $3^{-21}$ suggests that for each transaction, the document lists the name of the buyer, the type and quantity of commodity being purchased, and finally the amount of taxes to be paid in terms of grains (rather than in cash). Lines $3^{-6}$ are tax records from the previous day. Lines $7-8$ are names of parties of transaction on the present day. The 1oth line features prints and signatures. The 11th records the total sum of taxes raised on the sixth day of a certain month: 3 dan 4 dou 1 sheng. Lines 12-21 are an account of purchase and sell taxes by single transactions. The following is a literal translation:

$\cdots$

??? purchases 2 pi cloth tax 1 dou 2 sheng

"Prosperous Old House" (父拼誁) purchases 3 sheep tax 2 dou 8 sheng “Old House?” (尣拼?) purchases 1 sheep 4 black goats tax 3 dou 2 sheng Mingbu “? Force, mount” (嚆㣪?) purchases 1 sheep tax 1 dou 2 sheng

The main keeper of the document: Weiyi

\footnotetext{
44 Russian Collection of Khara-Khoto Manuscripts 15, p. 65.

45 TN: That is, to take 预 [kju] as the Chinese 繳 (raise, levy), and 呀姜 [kwa ] as 官 (office, officer).

$46 \quad$ Russian Collection of Khara-Khoto Manuscripts 14, p. 144.
} 


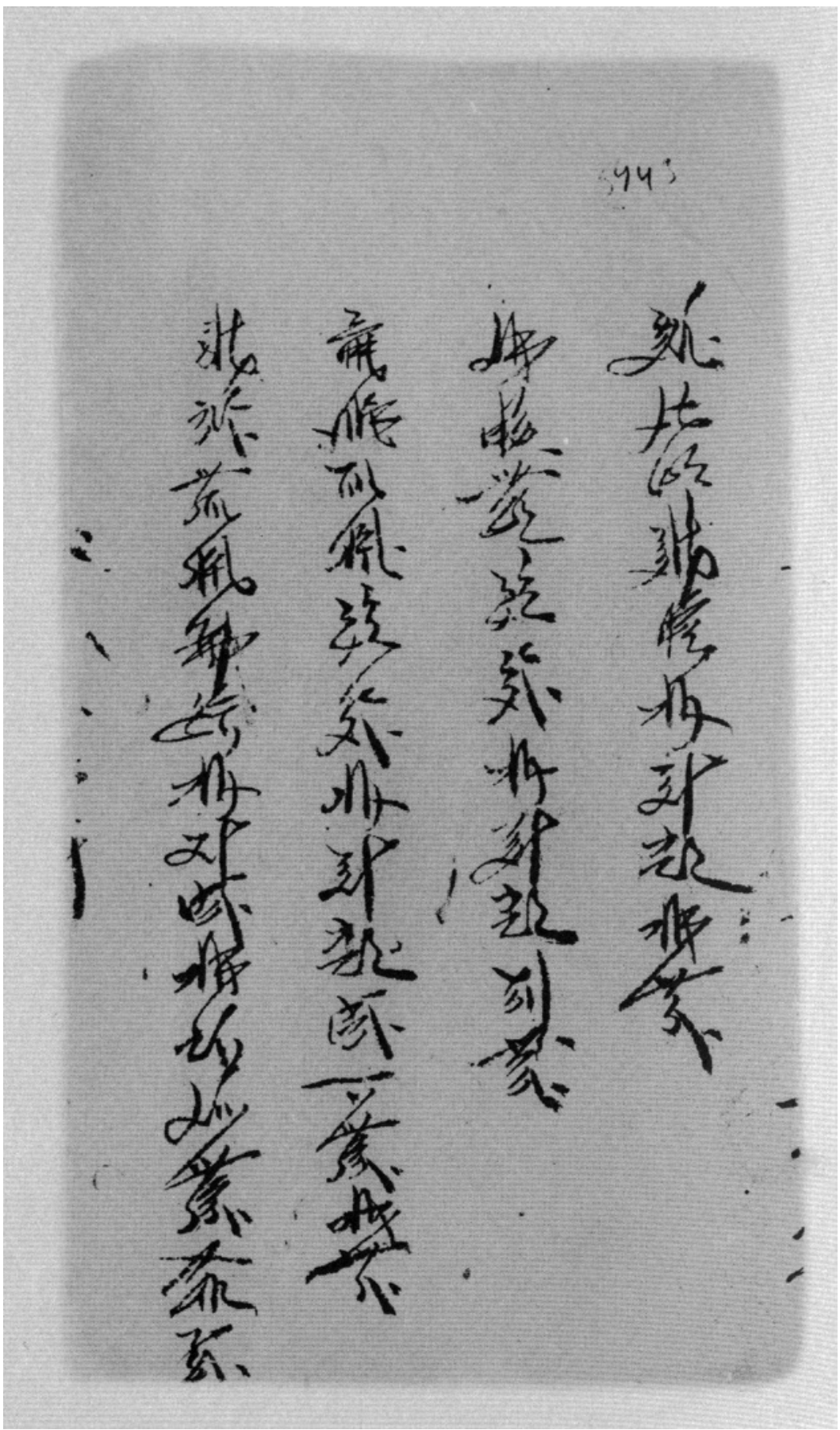

FIgURE 93 Инв. No. 5943-1: Account of transaction taxes 


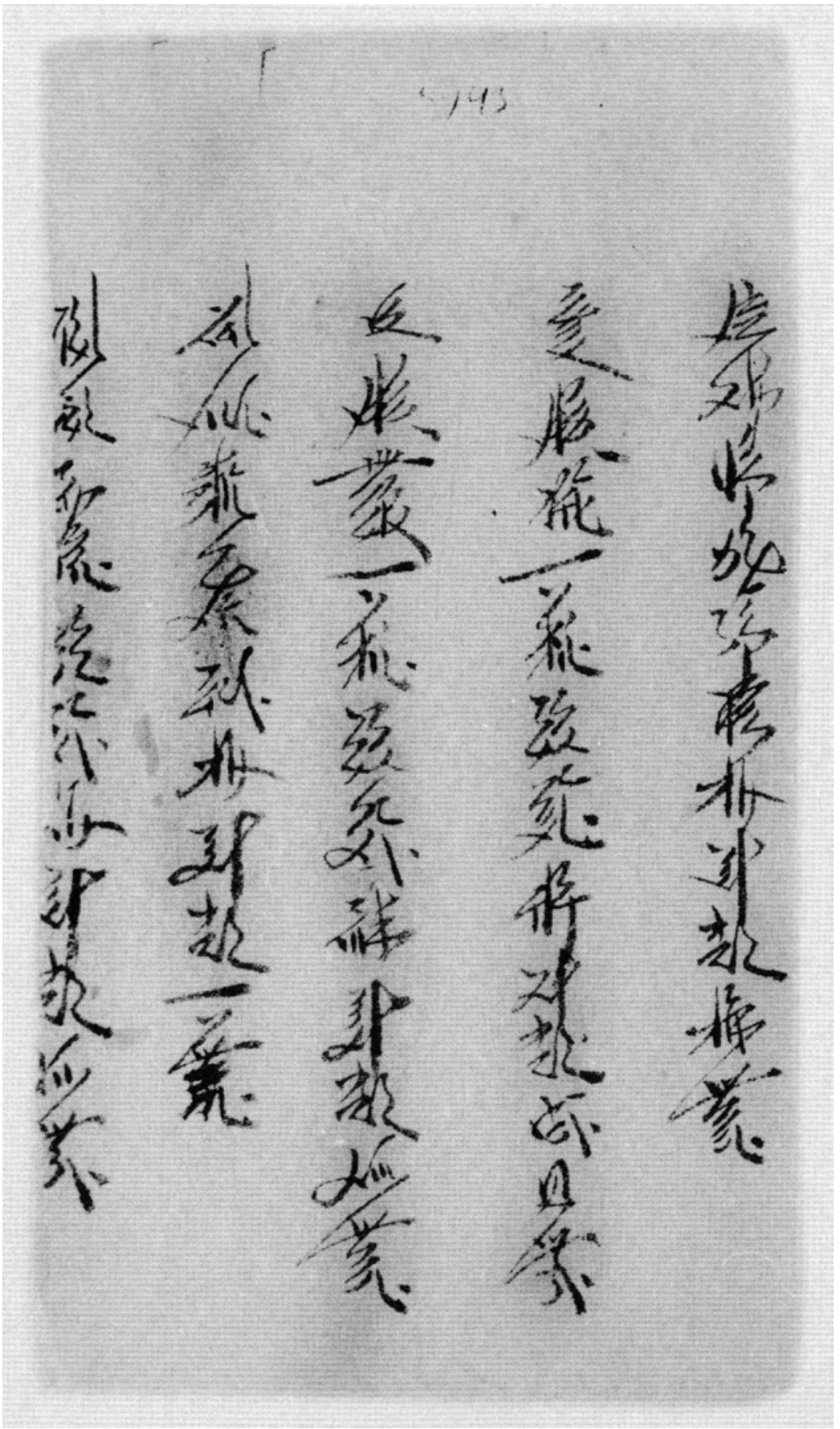

FIGURE 94 Инв. No. 5943-2: Account of transaction taxes 


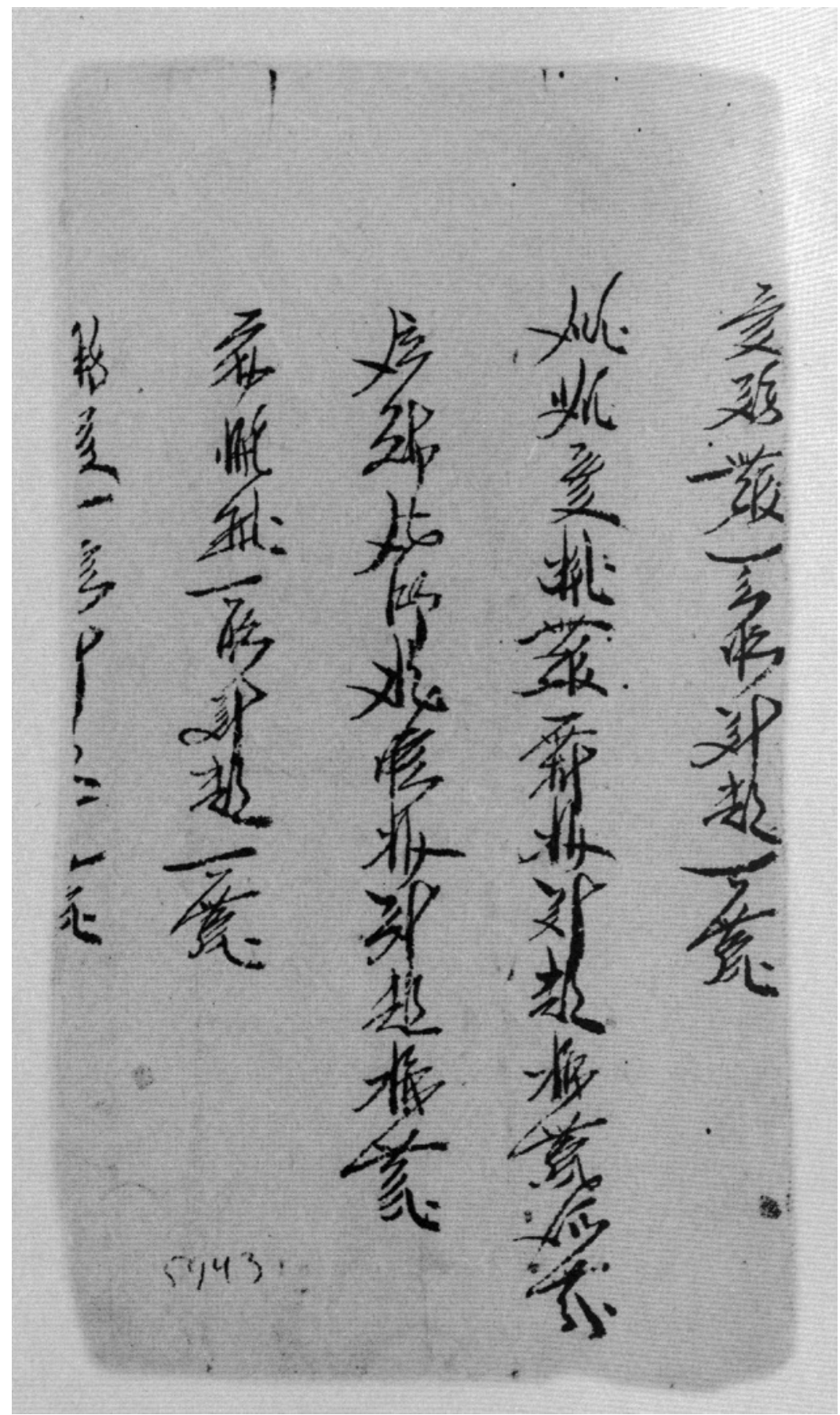

Figure 95 Инв. No. 5943-3: Account of transaction taxes 


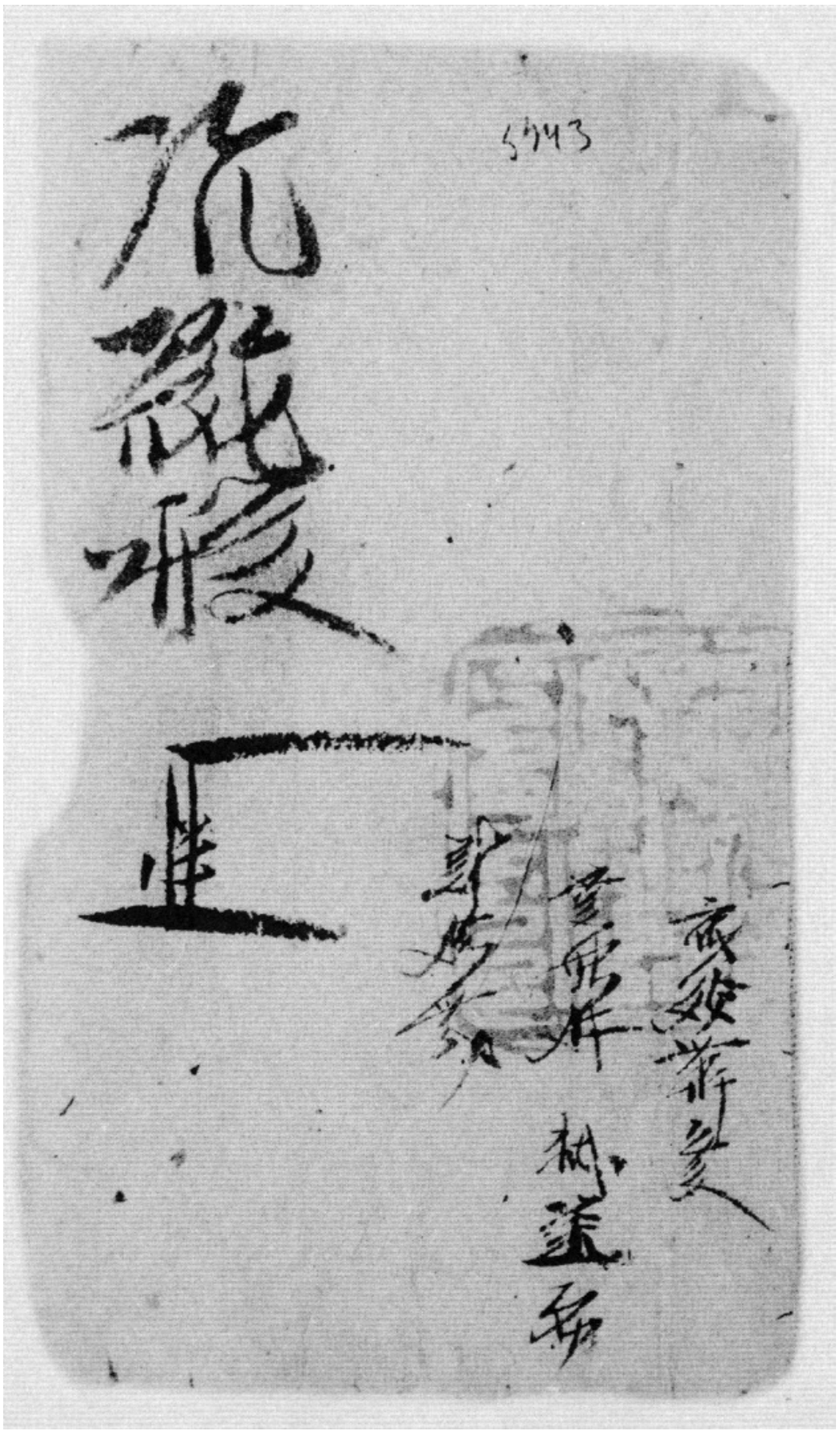

FIgURE 96 Инв. No. 5943-4: Account of transaction taxes 


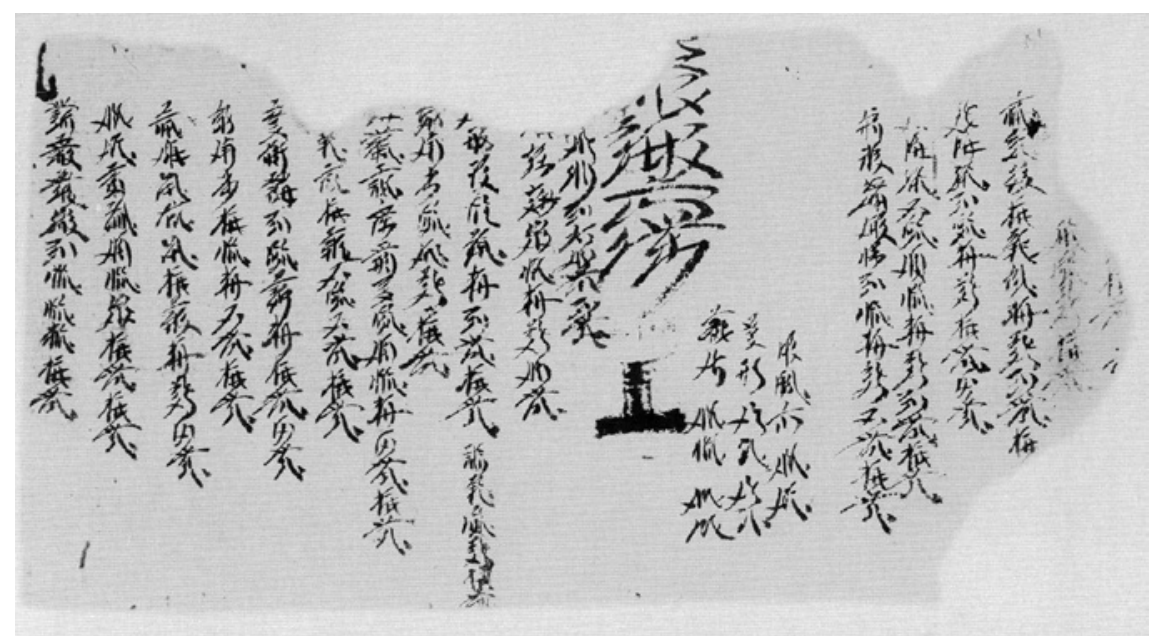

FIGURE 97 Инв. No. 6377-13: Account of transaction taxes

? borrow ??

Warehouse Supervisor: Weiming ??

... Senior Official (large characters) (prints)

... sixth day, 3 dan 4 dou 1 sheng

...??? purchases black goat tax 4 dou

... nu (揜)? Purchases cattle 3 dou 2 sheng Zhu? Sheep tax 2 dou

Zhang Nuzi (预㛔诮) sheep tax 2 dou

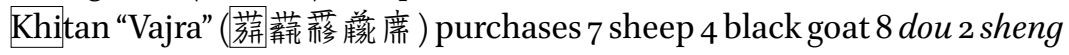
??? 2 'turned' 1 sheep 1 dou 2 sheng

Li Fanmao (麦修碾) purchases 3 sheep turned 2 dou 8 sheng

Zhang Nuzi purchases 2 black goat 1 dou 2 sheng

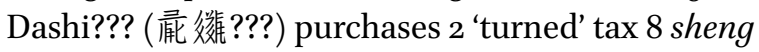

Weiyi?ling (㷋後善?解) 4 female sheep 2 dou 2 sheng

Shijun "the Joyful Iron" (爰微) 3 black goat, baby lamb 2 dou

The taxes "turned" may refer to paying taxes for the purchase of dead sheep. One could tell from this piece of record that to purchase one $p i$ of cloth, one has to pay 1 dou 6 sheng of tax. The purchase of one sheep is taxed 6-9 sheng. It is mentioned earlier that the price of each adult female sheep is 1 dan 5 dou, an adult sheep costs 1 dan, and a lamb costs $7 \mathrm{dou}$. The transaction tax falls in the range of $5 \%-10 \%$ of the price of sheep. As for cattle, the purchase of each animal is taxed 3 dou 2 sheng. If the unit price of cattle is indeed 4 dan of assorted coarse grains, then the transaction tax rate seems to have been set 
around $8 \%$. To purchase one black goat, one has to pay 4-6 sheng of tax. The transaction tax for buying a dead sheep is 4 sheng. All evidence seems to suggest that Western Xia raises high transaction taxes from its markets. The manuscript Инв. No. 6377-13 features a red seal of the House of Sell and Purchase Taxes, with prints and signatures, as well as those of the warehouse supervisors. The format of the text suggests that the record of transaction taxes is an official government document. All taxes are received and deposited in the government's designated warehouses.

The following is a summary chart of those accounts of transaction taxes that are legible enough for interpretation: (All registered numbers in the first column begin with "Russian Collection of Khara-Khoto Manuscripts Инв. No.").

These are merely a small fraction of the entire body of transaction tax accounts found and identified in Khara-Khoto, and yet, this morsel of information is enough to shed light on the diversity of goods traded in Western Xia. Apart from cloth and sheep, commodities also include land, gold, and even human beings.

CHART 11 Account of transaction taxes

\begin{tabular}{|c|c|c|c|c|}
\hline No. \# & Goods purchased & Quantity & Tax levied & Tax per unit \\
\hline $4790-3$ & human beings & & $\begin{array}{l}1 \text { dan } 3 \text { dou? \& white } \\
\text { cloth }\end{array}$ & \\
\hline $4790-3$ & camels & & wheat 3 dou & \\
\hline $4790-4$ & cloth & & wheat $1 \mathrm{dou}$ & \\
\hline $5943^{-1}$ & land & & barley 2 dan 4 dou & \\
\hline $5943-3$ & gold & & wheat 2 dou 4 sheng & \\
\hline $6377^{-13}$ & cloth & $2 p i$ & 1 dou 2 sheng & 6 sheng \\
\hline $6377^{-13}$ & sheep & 3 sheep & 2 dou 8 sheng & 9 sheng + \\
\hline $6377^{-13}$ & sheep & $\begin{array}{l}1 \text { sheep, } \\
4 \text { black goats }\end{array}$ & 3 dou 2 sheng & \\
\hline $6377^{-13}$ & sheep & 3 black goats & 1 dou 2 sheng & 4 sheng \\
\hline $6377^{-13}$ & sheep & 1 & 1 dou 2 sheng & \\
\hline $6377^{-13}$ & sheep & $\begin{array}{l}7 \text { sheep, } \\
4 \text { black goat }\end{array}$ & 8 dou 2 sheng & \\
\hline $6377^{-13}$ & sheep & 3 lamb & 2 dou 8 sheng & \\
\hline $6377^{-13}$ & sheep & 4 sheep & 2 dou 2 sheng & \\
\hline $6377^{-13}$ & sheep & $\begin{array}{l}3 \text { sheep \& } \\
\text { black goats }\end{array}$ & $2 \mathrm{dou}$ & \\
\hline
\end{tabular}


In addition, three pieces of tax account fragments have been identified in the midst of Khara-Khoto documents at the National Library of China. The tax information is written on top of yellow hemp papers originally used as covers or layers of books. Written in the Tangut cursive script, some of the content is still legible despite damages at the beginning and the end.

Amongst these manuscripts, No. 125 (7.17X-43) records the "purchase of one cattle? Tax 2 dou 4 (sheng)," "added one camel, tax 3 dou." No. 127 (7.17X-45) speaks of "one person Jin?wan beef tax 1 dou 8 sheng coarse [grains]; one person Hongluo 'Gold and Iron' purchases cattle and camel skin, tax 1 dou 2 sheng coarse [grains]." This document reveals that the Tangut government levied taxes on trades of livestock, meat, and animal skins.

No. 126 (7.17X-44) shows that the transaction of human beings is also liable for tax. "purchase of servants, tax 6 dou." This statement reflects the dire reality of Tangut trade of human beings (nupu: serfs, servants) and the taxes raised therein. Upon the completion of the transaction, the parties involved had to pay taxes as if they were trading livestock. The only difference lied in the

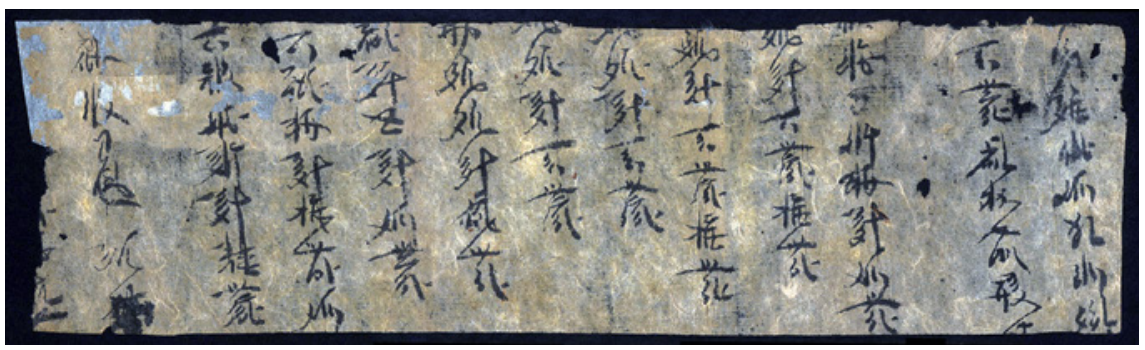

FIGURE 98 National Library of China No. 125 (7.17X-43): Tax account

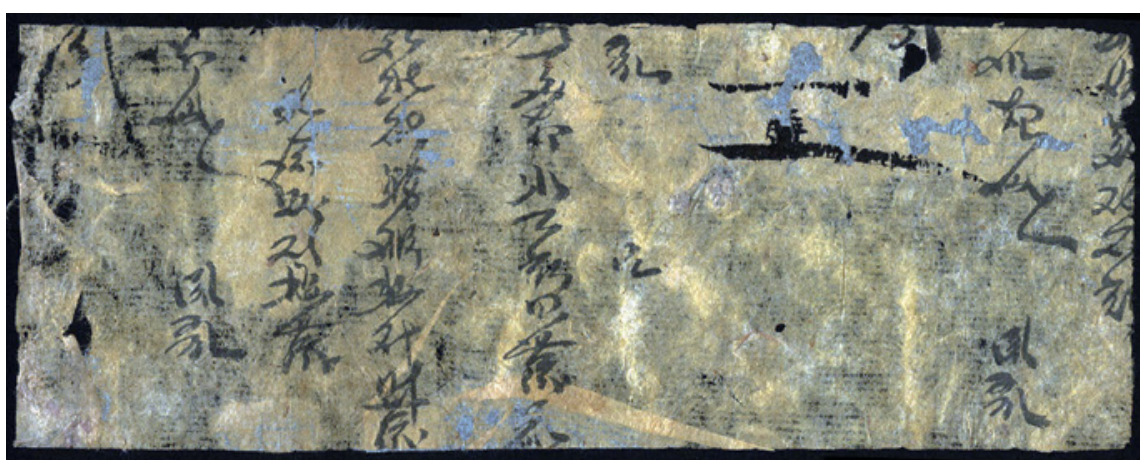

FIGURE 99 National Library of China No. 126 (7.17X-44): Tax account 


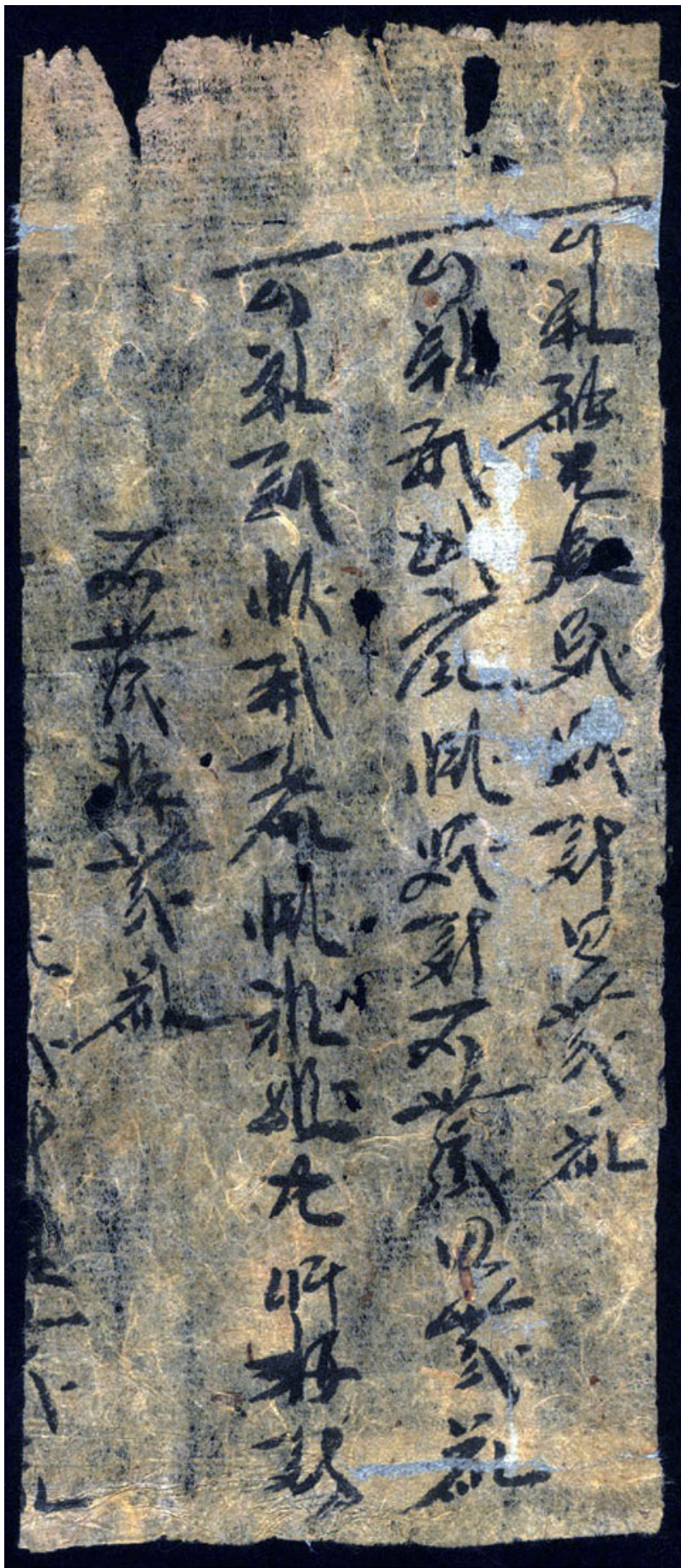

FIGURE 100

National Library of

China No. 127 (7.17X-45):

Tax account 
higher tax rate for trading humans. The reason is none other than the generally higher prices of human beings than those of animals in Western Xia. ${ }^{47}$

The sources analysed above give rise to the following conclusions:

1. The goods most frequently subject to transaction taxes are commodities for daily consumption such as cloth, and livestock such as sheep, camel, cattle, and horse. Valuables such as gold are also traded and taxed.

2. As a type of fixed asset, land is taxed when the ownership concerned is traded and transferred. As a very special kind of commodity, human beings are also sold and purchased. The transaction of live human beings is limited to shijun (semi-slaves of military origins) and nupu (serfs and servants), and is subject to taxation. High tax rates are applied to the trade of land and human beings.

3. Concerning the same type of livestock, the transaction tax rate depends on the age, size, and condition of the animal.

4. Most of the transaction taxes are paid in kinds, in terms of grains. The Tanguts minted and circulated their own currency, in addition to Song coins. However, the prevalence of selling and purchasing tax payments in grains speaks to the smaller scope and stricter limitations of trading with cash in Western Xia. The Khara-Khoto materials, especially at the local level, testifies to this.

5. A holistic view of the transaction tax documents yields the conclusion that the Tanguts adjusted their transaction tax rate according to the turnover and trade volume.

In addition to the Three Bureaus of fiscal and financial policies on the Chinese model, ${ }^{48}$ the Tangut Empire tasked the Bureau of Transfer and Transportation with the duties of adjusting and evening tax rates to balance the government's budget. These institutions borrowed more or less from the political organisation in the Central Plains. But the Tanguts also established an institution of its own design, the Bureau of Revenue and Repository, which was in charge of maintaining storage, income, and expenses. First founded in the early Tangut period, the institution lasted through the final years of the empire. The Bureau of Revenue and Repository was a mid-level governmental agency, run by four

47 Shi Jinbo, 2004 (b).

48 TN: The author refers to the Tangut fiscal and financial institution as the equivalent of the Three Bureaus (三司) of late Tang and Song Dynasty, not those from Han to mid-Tang dynasties, or after the Song Dynasty. The Three Bureaus of Western Xia would have fulfilled the same bureaucratic functions of the Bureau of Salt and Iron (鹽鐵司), the Fiscal and Tax Bureau (度支司) and the Census Bureau (戶部司) of the Song Empire. 
main officers, four 'Order-Bearers' (Chengzhi), three 'Administrators' (Du'an), and four assisting Clerks (Antou). ${ }^{49}$

The two main offices overseeing taxation were the House of Taxation in Capital Zhongxing and the House of Taxation in the Central Commander's Region. The office in the capital was run by one Clerk (antou), four agents (sili), two junior supervisors, and two accountants. In the Central Commander's office in Lingwu County, there were two agents, two junior supervisors, and two accountants. There were, in addition, 18 offices affiliated with the House of Taxation on the Sales of Alcohol Distiller's Yeast, all of whom were equipped with the expertise of two junior supervisors and two accountants. ${ }^{50}$ The Tangut government obviously placed great emphasis on taxing alcohol fermentation as a source of revenue.

\section{Accounts of Monetary Loans and Interests}

The discovery of a distinct type of documents amongst the Khara-Khoto manuscripts: accounts of monetary, property loans and their interests, testify to the professional practice of loaning money and physical properties in the economic history of Western Xia. These accounts, for a long time unknown and thus unexamined, provide exhaustive information on how the Tanguts loaned money and properties.

A class of monetary and property loan accounts, such as the manuscript Инв. No. 23-10 and the Инв. No. 23-11, are all page fragments hand-written in the cursive style. The Инв. No. $23^{-10}$ is $15 \mathrm{~cm} \times 3^{2} \mathrm{~cm}$ in size, with 19 lines of Tangut writings, as well as some crossing and markings. Near the end, there are also traces of some broken pieces that look like an account of the military chao. Then, the manuscript Инв. No. $23^{-11}$ is $15 \mathrm{~cm} \times 3^{2} \mathrm{~cm}$ in size, also featuring 19 lines of Tangut. The formats of these two accounts are similar, in that each transaction is recorded in a total of two lines. The first line, written in large font, documents the date of the monetary or property loan, names of the borrowers, the principle value and amount of the money or property in the loan. On the right, there is a line of writings in a smaller font that details the interests applied. In the manuscript Инв. No. 23-10, for example, shows the second transaction as: "... 18th day ?wang" "Iron of the Old House: principle money 2 guan ..." on the left, and "interest 400 mace to be returned" on

49 Revised Laws of Heavenly Prosperity 10, "On the Order of Political Offices," p. 368.

50 Revised Laws of Heavenly Prosperity 17, "On the Transfer and Transportation between Bureaus," pp. 529, 532. 


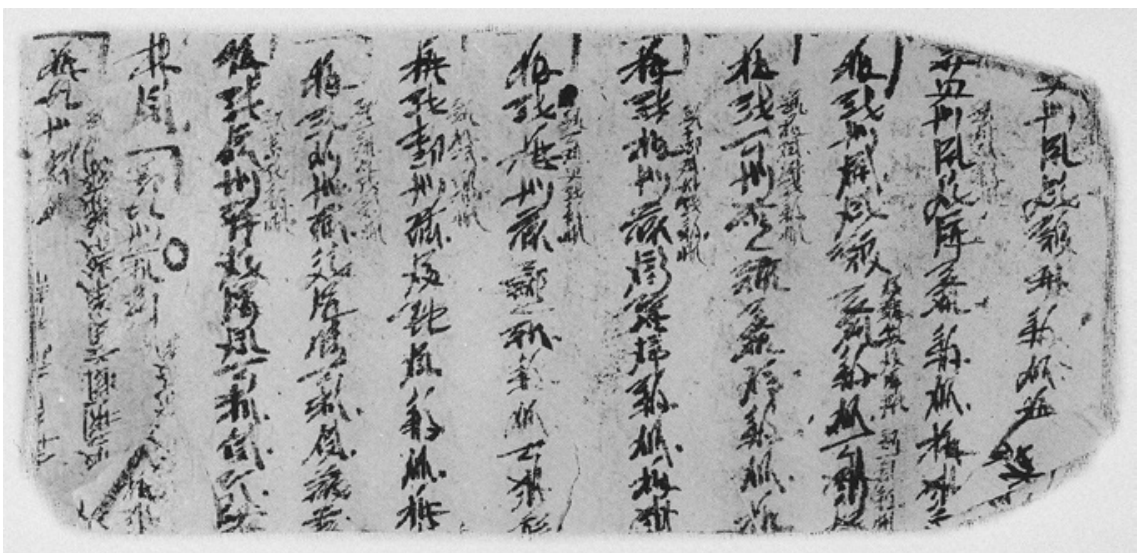

FIGURE 101 Инв. No. 23-10: Account of loan interests

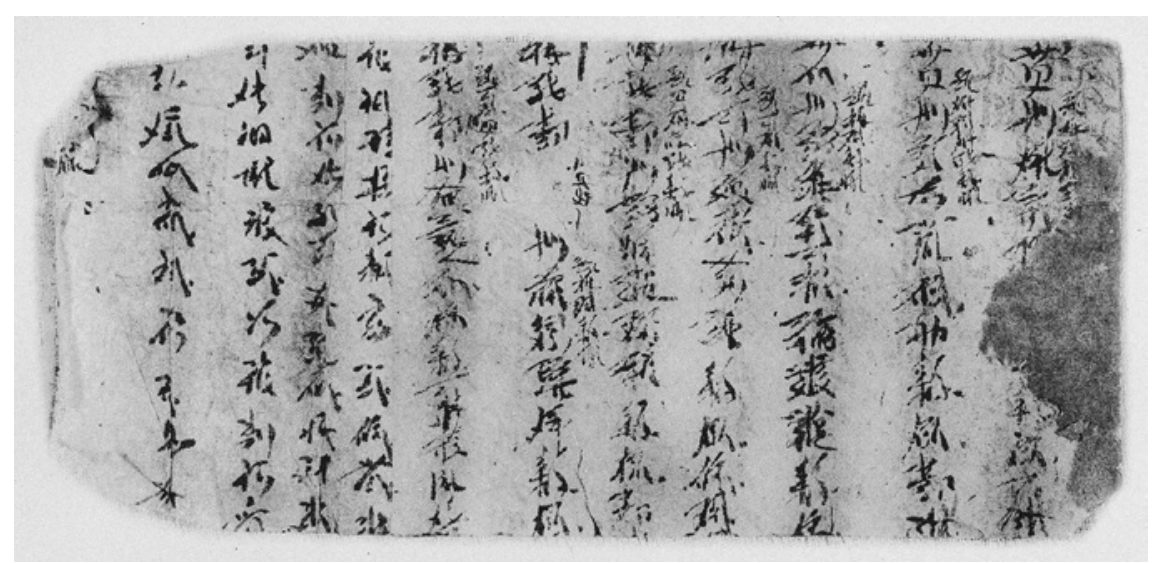

FIGURE 102 Инв. No. 23-11: Account of loan interests

the right. Another example is the manuscript Инв. No. 23-11. Its fourth listed transaction reads, “... 21st day, Duluo 'with Prosperity': principle money 500 ..." on the left, and "interest 100 mace to be returned" on the right. The character after " 500 " should be the unit of currency, "mace." The interest rate across these contracts is approximately $20 \% .51$

Interest rates in cash or property loans can also exceed $20 \%$. Such is the case in the fifth transaction documented in the manuscript Инв. No. 23-11, where the principle is over 3 guan of cash, and the interest 850 mace-in other

$5^{1} \quad$ Russian Collection of Khara-Khoto Manuscripts 12, pp. 6-7. 
words, a $35 \%$ interest rate. Others are below $20 \%$ : in the third transaction in the manuscript Инв. No. 23-10, the principle is around 1 guan of cash, but the interest is only 100 mace, at the rate of about $10 \%$.

So far, these manuscripts do not seem to indicate the time and duration of the loans. Therefore, it is technically unknown whether these interests are monthly or annual dues. But in the light of the $50 \%$, or $20 \%-100 \%$ range of interest rates in multiple grain loan contracts found in Khara-Khoto, and given that most daily interest rates are around $1 \%$, only rising up to $20 \%$ in a month, it is possible that the interest rates listed in these cash and property accounts are on a monthly basis.

What are the identities of the borrowers? Some are Dangxiang Tangut ethnics: Maze and Duluo, whilst are Han Chinese, such as the Zhangs. The diversity of surnames testifies to the broad and inclusive participation in the financial activity of monetary loans.

Apart from cash, a type of property recorded in these loan contracts is cloth. But the interest is paid in terms of cash. In both the 8th and 9th transactions in the manuscript Инв. No. 23-10, for example, the loan consists in a piece of cloth. The interest rates applied are 150 and 30 mace, respectively.

There is yet another type of loan and interest account that is by far the richest in detail. An example is the Инв. No. $1576-2$, a $24.8 \mathrm{~cm} \times 31.8 \mathrm{~cm}$ manuscript in two patched fragments handwritten in the cursive style on a piece of layering paper in the cover of a Buddhist sutra. The two pieces, both suffering some damages and losses, contain 13 and 10 lines of Tangut, respectively, and some checkmarks and crossings. The upper page is larger and more informative, including up to 10 transactions. ${ }^{52}$ Due to the small font and the casual handwriting, some of the characters are extremely hard to identify and interpret. It is clear, however, that each transaction begins with the date. Due to the damages on the upper side, most of the years are lost. But the months are there in order, and very much legible: second, eleventh, fourth, fourth, first, second, fourth, second, seventh, third months. It is probably not the account of the same year. In the 8th transaction, there is an entry for a loan in the second month, which is repaid in the eleventh year of Year Hai. So, the other transactions probably also took place in or around the year Hai, but as for which year of Hai, it remains a mystery.

In the entry for each transaction, the data on the quantity of cash or grain loans is registered under each name, followed by the amounts of interests or the total cash or grains to be repaid at the end. The following is a tentative analysis based on the more complete, legible, and deployable of the data in these manuscripts. 


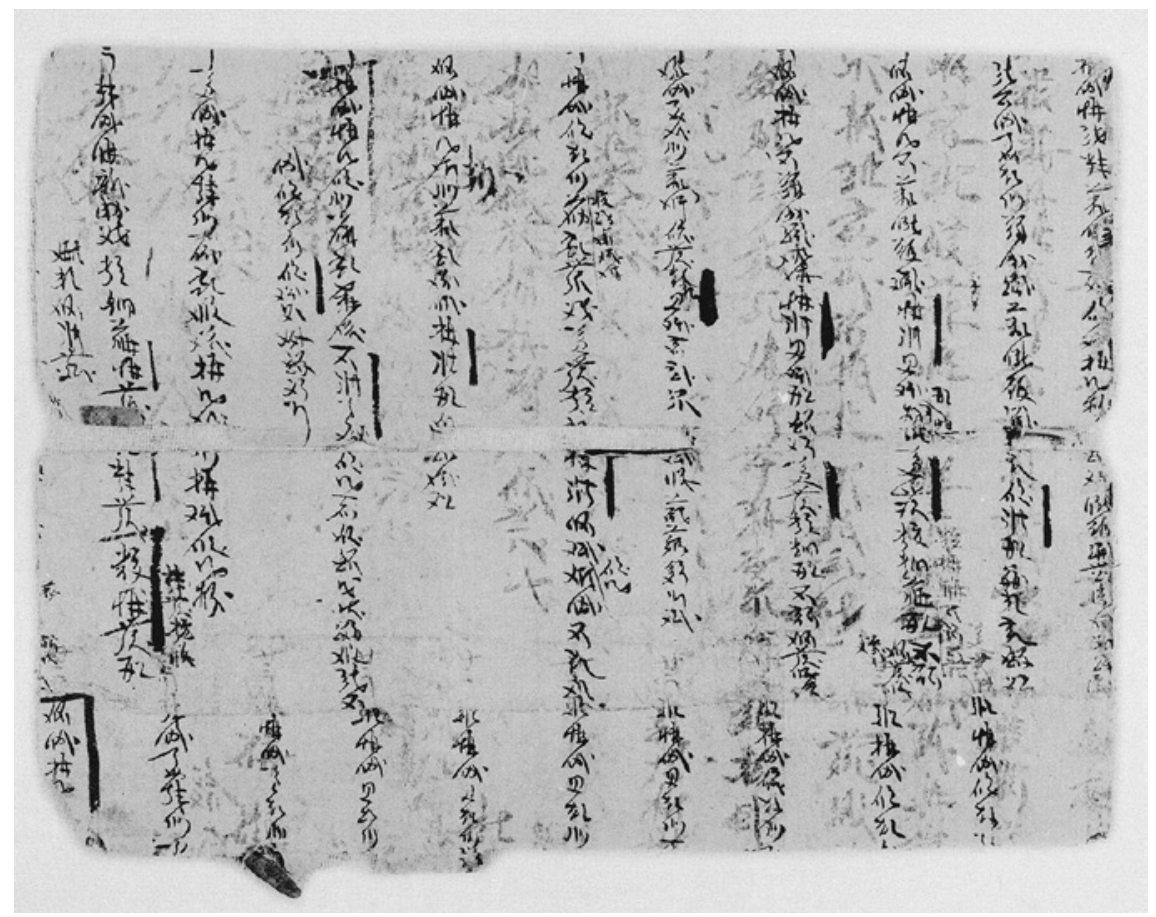

FIGURE 103 Инв. No. 1576-2: Account of loan interests

Both borrowers in the third and fourth transactions takes out "a loan of cash in 2 guan 800 mace, interest: 7 dou of beans; let the total repayment be 1 dan 4 dou." Here, the principle and the interest are 7 dou each, at the interest rate of $100 \%$. The seventh transaction is fairly simple: A lady named Luo takes a loan of 2 guan of cash, and pays back 3 guan, at the interest rate of $50 \%$. And in the light of all we know about Tangut food prices, if $7 \mathrm{dou}$ of grains is worth 2 guan 800 mace, then the price of beans is around 400 mace per dou. And since grains are usually purchased at 200 mace per $d o u$, and wheat at the price of 250 mace per dou, the 400 mace here is much higher than the common prices of grains elsewhere.

Another type of monetary loan document is best described as somewhere between a loan contract and a proper account. Such is the case in the manuscript Инв. No. 1523-24, a $20.8 \times 33.7 \mathrm{~cm}$ document of monetary loan with 17 lines of Tangut writings, that suffers some damages both at the front and at the end. ${ }^{53}$

The format of this document is clear and distinct: each transaction begins un-indented, aligned at the top of the paper. From the second line on, till the 




FIGURE 104 Инв. No. 1523-24: Document of monetary loan

end of the same entry, there is an indentation of 2 characters' space. The present document shows the last four lines of a given transaction, and starts a new transaction record in the $5^{\text {th }}$ line. This entry begins with "One entry: in the Third Renchen Year of the Qianyou Era, on the fifth day of the sixth month, the contract set by Dashi ??" The third Renchen Year of Qianyou is the third year of Qianyou (1172 AD). The contractor is a certain "Dashi" (Dayi) which, given that "Khitan" is also a Khitan surname, and "Xianbei" a Xianbei surname, could actually be the name of a person of Arabic lineage. But whoever he is, there is no question that he borrowed 700 guan of cash, at the daily interest rate of 8 mace per guan; the total sum of both the principle and the interests is due to be repaid in 100 days. At this rate of $0.8 \%$ per day, in a hundred days he would have paid 800 mace per guan of his cash loan. This amounts to an $80 \%$ cumulative interest rate, not a low rate at all. Since the principle loan is 700 guan, in a hundred days, the total interests due are $700 \times 0.8 \%=560$ guan. So, the borrower has to repay 700 (principle) +560 (interest $)=1260$ guan, in total.

The document also specifies that, in case of an overdue repayment, an additional daily interest of 5 mace or less per guan is applied to the accumulated debt, starting from the first day past the due date. The $5 \%$ is no small burden upon the borrower. A delay of 10 days would result in 35 guan of cash as a penalty fee.

We have seen in the manuscript fragments the references to at least two Khitans, whose surnames are none other than 'Khitan.' In this entry, the 


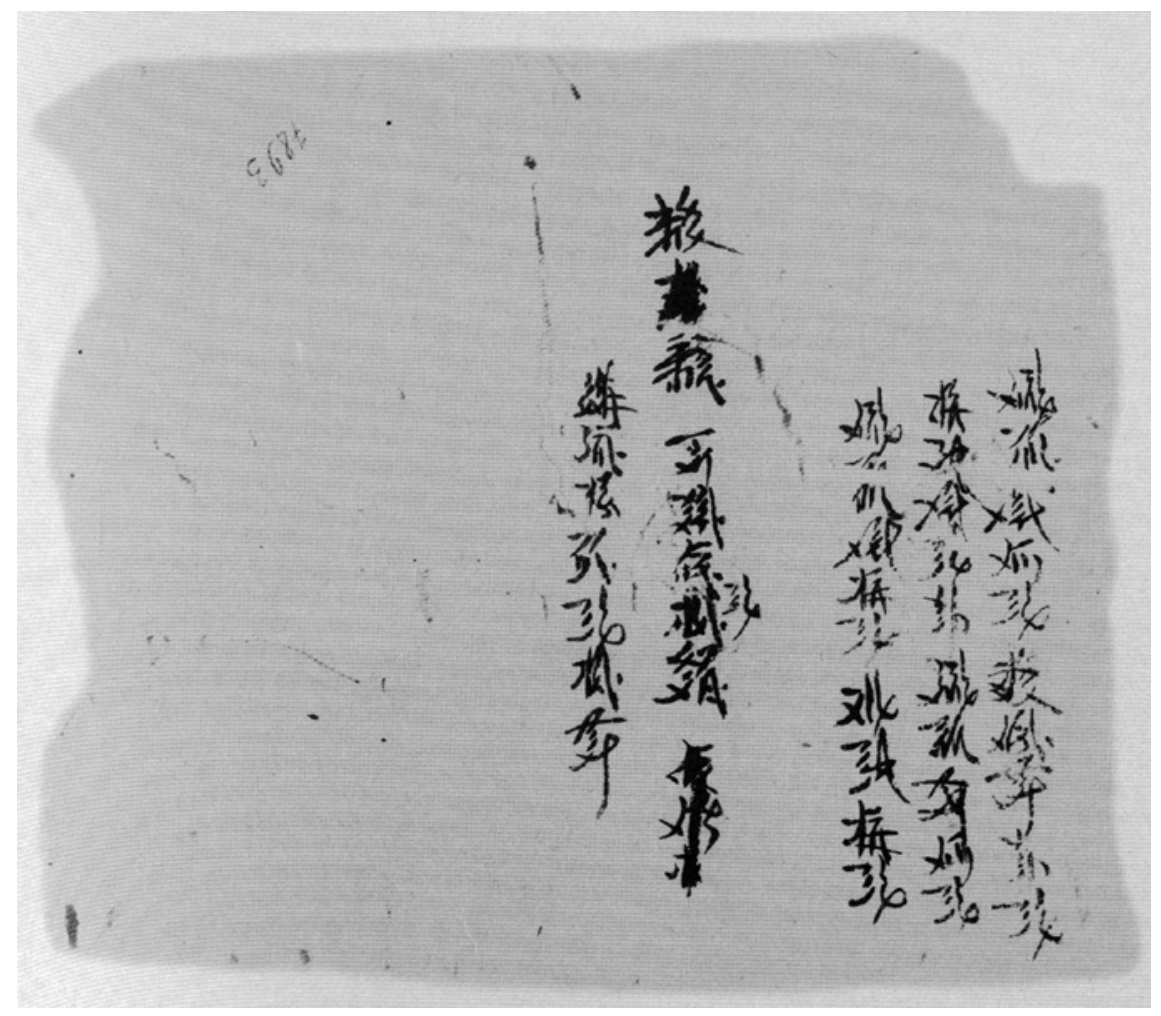

FIGURE 105 Инв. No. 7893-15: Statistical account

borrower's surname is Dashi (Dayi). The loan is a large one, and at a high interest rate. Rather than an ordinary personal loan, it could as well be a business loan. It is no secret to historians that the Arabs were active in trans-Eurasian trade. Perhaps this document provides us with a glimpse at the commercial activities of the Arabs in the era of the Tangut empire.

In rare occasions, Tangut contracts officiate loan transactions in silver. The manuscript Инв. No. $7893^{-15}$ is a $19 \mathrm{~cm} \times 22.2 \mathrm{~cm}$ fragment with 5 lines of Tangut handwritings and some edits and erasures. ${ }^{54}$

The first 3 lines are detailed accounts of 6 transactions by different individuals. The last 2 lines are summary statistics. The following is a simplified translation:

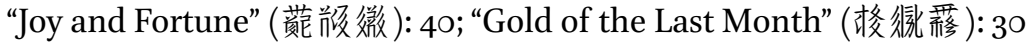

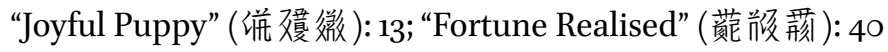




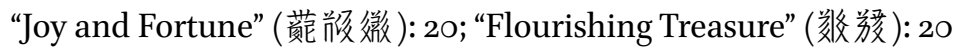

Assorted things: ${ }^{55} 15$ o liang silver

Earlier: ${ }^{56}$ all the 10 liang [of silver]

The total sum of the six transactions is 163 liang in silver. The first line of the summary statistics reads 15 o liang; the second line, however, notes that there was a previous entry for 10 liang. Still, there is a 3 liang gap unaccounted for in the fragment we have. This rare document, possibly a cash loan account, is a record of statistics in in the currency of silver. Although very few Khara-Khoto documents refer to silver at all, this account shows that silver cash was, after all, in circulation in the Khara-Khoto region.

Accounts of Grain Loans and Debt

The Khara-Khoto economic records include not only a great amount of grain loan contracts, but also accounts of grain debt and loans. Most of these grain loan accounts are fragments of the original, handwritten on layering papers or cover pages of Buddhist sutras. Expectedly, the single-paged accounts are easier to survive in full length. Most of these grain accounts are summary statistical accounts of grain loans over a period of time. Although they are not contracts in the legal and the technical sense, the grain loan and debt accounts are by their nature interlinked with grain loan contracts. The accounts can be regarded as cumulative, concentrated, and comprehensive overviews of multiple contracts.

\subsection{Grain Loans}

Some of the grain loan documents discovered in Khara-Khoto are not separate contracts of specific transactions, but summary accounts of individual loans. One example is the manuscript Инв. No. 2176, in two page-fragments. Инв. No. 2176-1 is an account of grain loan in the Renyin year of Qianyou era, handwritten on a piece of protective layering paper from another printed text. of grain loan. The two pages are patched together $18.9 \times 16.4 \mathrm{~cm}$, with 10 and 8 lines of Tangut cursive writings, respectively. The first line marks the date and year: "Renyin Year of Qianyou, first day of the third month" - that is, $1182 \mathrm{AD}$. The manuscript Инв. No. 2176-2 is a similar handwritten copy, also on a protective layering paper. It is $19.4 \times 15.7 \mathrm{~cm}$, with 11 and 9 lines of Tangut writings

55 TN: I am not entirely clear what these two characters are doing in this context.

56 These two characters look like 猚鼎 [də_no], lit. earlier in the past; before. 
on each of its pages. ${ }^{57}$ In terms of the period, it is a rather early account of grain loan.

The Russian manuscript Инв. No. 2176 is an account of grain loan that is relatively well-preserved at the top and the bottom, but suffers some damages and loss of information on the left. The first line begins at the top, without indentation, with the title of the account: "Renyin year of Qianyou, first day of the third month, Grains." The two-character word for "grains" or "foodstuff" is

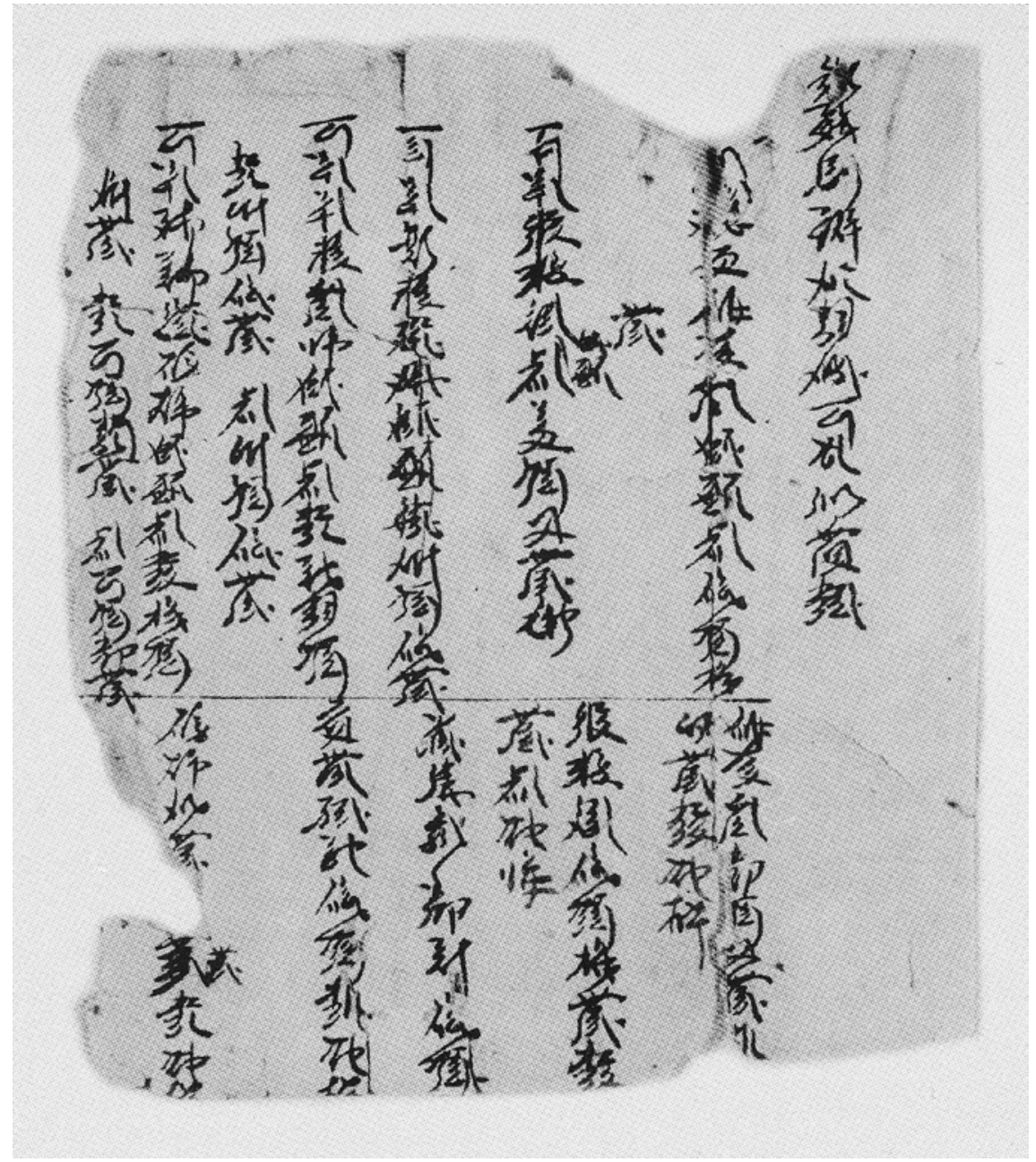

FIGURE 106 Инв. No. 2176-1: Renyin year of Qianyou, account of grain loan

57 Russian Collection of Khara-Khoto Manuscripts 13, p. 64. 


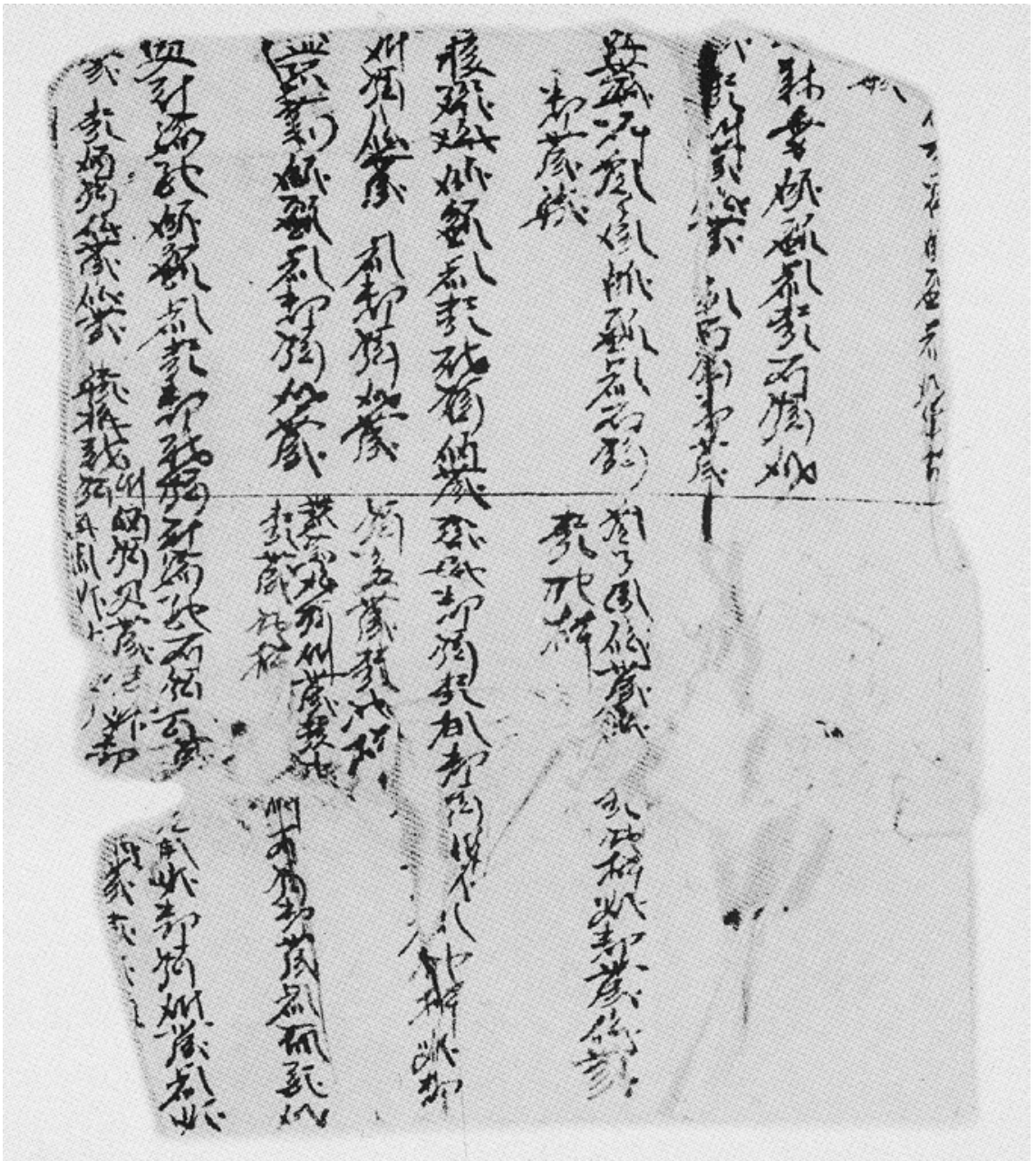

FIGURE 107 Инв. No. 2176-2: Account of grain loan

带㸚致 [śio_w śji]. In the Fan-Han Pearl in the Palm, the expression is translated as “斛豆”一 a generic reference to grain, foodstuff, and agricultural produce. ${ }^{58}$ This account of grain loans in the thirteenth Renyin year of Qianyou in Tangut Emperor Renzong's reign (1182) documents the principle and interests of each

$5^{8}$ Huang, Zhenhua; Nie, Hongyin; Shi, Jinbo (eds.). Fan Han Heshi Zhangzhongzhu [番漢合 時掌中珠]: Fan-Han Pearl in the Palm. Yinchuan: Ningxia People's Press, 1989, p. 15. See also, Russian Collection of Khara-Khoto Manuscripts 10. 
loan. Each transaction begins with the same legal formula: "one person ..." referring to the abstract moral persona of the debtor, under which is the actual name of each borrower, and further below, records of the types and quantities of grains in the loan. The following are 5 transactions listed at the top of the account:

Renyin Year of Qianyou, First Day of the Third Month: Grains One person: 数图䄈裳徽 [wa gu_dow zji-r bie_j] principle and interest: coarse grains 5 dan 2

dou

One person: Cao Ale (纽徕并, 微), coarse grains 7 dou 8 sheng?

One person: ?pu “Mother Dog” (㣪鹤秝) principle and interest: barley 6 dan 5 dou

One person: Yehe “Joyful Mount” (䍪䐘徽㥪) principle \& interest: coarse \& wheat 13 dan $^{59}$

Wheat 6 dan 5 dou; coarse grains 6 dan 5 dou

One person? 6 ?? “Luck and Joy” (枚微) principle \& interest coarse \& wheat 2 dan

6 dou wheat, 1 dan 3 dou coarse 1 dan 3 dou

There are, likewise, 5 transactions listed at the bottom of the grain loan account, with damages at the front and at the end. The manuscript Инв. No. 2176-2 is a similar kind of grain loan account, patched together with two page-fragments. The two-track system of both singing contracts and keeping accounts suggests that, historically, the Tanguts would compile the data in a number of their signed contracts into an account.

Another such account is the Инв. No. $7892-2 \mathrm{~V}$, a $22.3 \mathrm{~cm} \times 12 \mathrm{~cm}$ fragment with 4 lines of cursive handwritings in Tangut. This piece is hard to read, partly because the ink on the front and back pages intersect and overlap, mixing up the shapes and strokes of a number of characters. ${ }^{60}$

59 TN: It would have to be "coarse grains and wheat" because barley would have been included in "coarse grains," so "coarse grains and barley" is redundant.

6o Russian Collection of Khara-Khoto Manuscripts 14, p. 204. The title of the document is listed as "submission of political report" in the book format, whereas it is actually an account of grain loans. 
3)

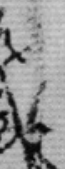

,

in

a

, 14 (n)

क⿺⿻一𠃋十

(24

:

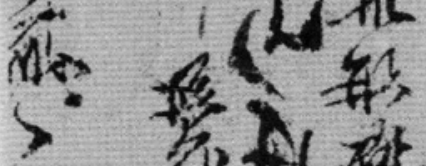

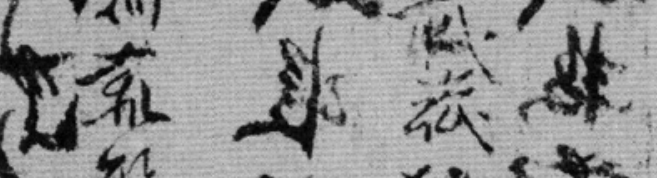

it if fid

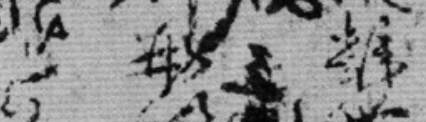
i) xinfing

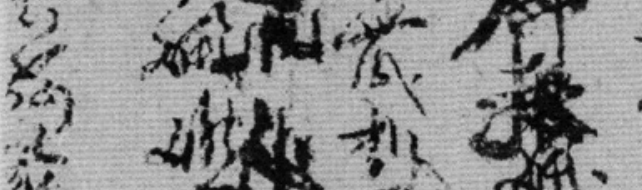

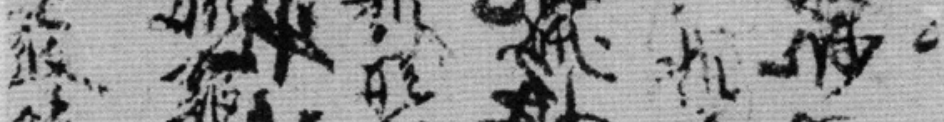

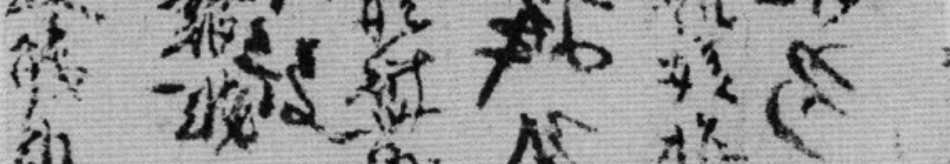

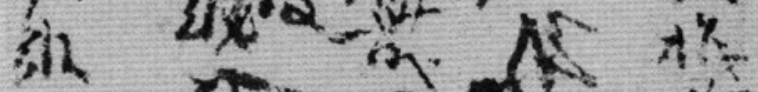

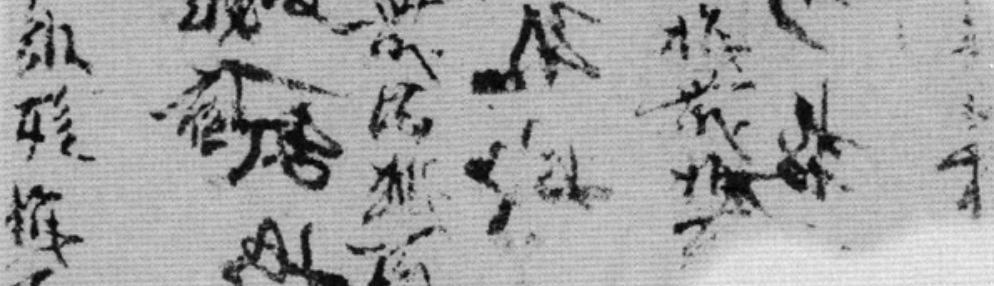

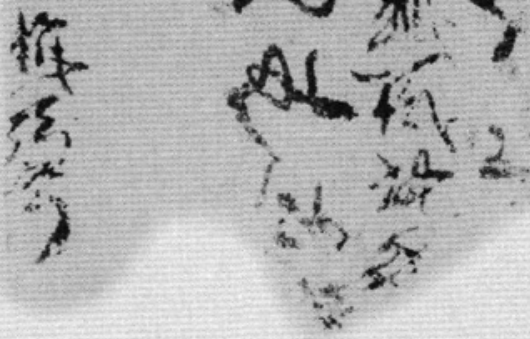

FIGURE 108 Инв. No. 7892-2V: Account of grain loan 
The following is a literal translation:

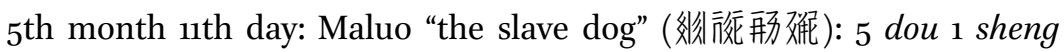
proso millet loaned 2 dou 2 sheng ...

Borrower: "the slave dog"

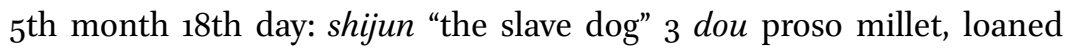
6 dou?? up??

Borrower: "slave dog"????

5 th month 18th day: Liang?? "treasure" 1 dan???, loan 2 dan ...

This particular account resembles a simple format of grain loan contracts: there is the time, the name of the borrower(s), the types and quantities of the grain loan(s), and the sum of debt repayment. But there is another line that repeats the name of the borrower. What is missing, however, is the signature and stamp of the borrower. Without notarising and sanctioning, the document is probably an account of grain loans rather than a proper legal contract.

In recent years, thanks to the superb organising and coordinating initiatives on the part of the Rare Books staff at the National Library of China, there has been a sustained effort to restore and compile the Tangut manuscripts at the Library. In that process, a number of new fragments of Tangut social documents have emerged, likewise from the front covers, back covers, and layering papers of Khara-Khoto Buddhist sutras. There is a total of 170 piece of papers, where more than 10 grain loan accounts have been identified. Most of these documents are individual pages that came off an entire account. Written in the Tangut cursive, these pages record the names of the loaners (creditors), the types and quantities of the grains, the amounts of the principle and the interests, etc. They are most likely to have been kept by the 'banks' - more precisely, the loaning or pawning shops_-as a back-up copy, or security copy. In all likelihood, rich Tanguts would hoard their surplus grains in these pawnshops or loan-shops. The financiers who run these shops would then coordinate the release of these loans and serve as an intermediary in paying back the creditors' interests. These accounts show that, whichever type of grains are concerned: wheat, barley, beans, and peas, and whatever the quantity of the loan, the interest is stabilised at around 50\%. ${ }^{61}$

It is worth generalising the legal distinctions between a grain loan contract and a loan account. Crucially, the focus of the grain loan contracts is on the borrowers, the proper 'contractors' in whose name, stamp, and signature the contract obtains its legal force. In other words, the contract reflects the legal

61 Shi Jinbo, 2004 (a). 
relationship between the lender and the borrower, that is, the creditor and the debtor. In contrast, an account of grain loan is creditor-centred, for it is recorded by, for, or on behalf of the lender, in order to keep track of all the loans that have been released, and are expected to generate revenues in due time. It reflects the legal relationship between the creditor and the intermediaries. These intermediary agents or representatives, in particular the pawnshop 'bankers,' would add their own interests on top of the 50\% expected by the creditors, in order to also extract some profits out of the loan arrangements. They profit from the loans without even pledging any principle in the first term.

These grain loan accounts are found in more than ten morsels of papers, which are probably taken out of the same booklet of accounts. The materiality of the paper is best described as thin hemp paper, and the handwritings are mostly cursive Tangut, written on both pages of the papers. Some suffer more damages at the bottom, whereas others are broken near the top. Below are some rough translations of some of the more legible and better-preserved manuscripts.

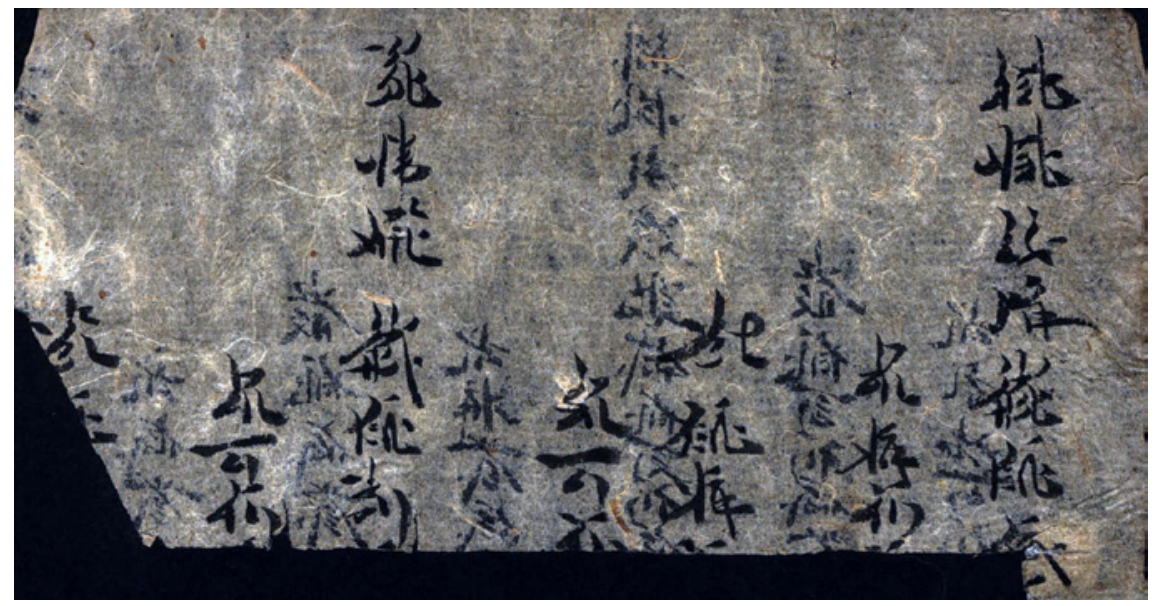

FIGURE 109 National Library of China No. 042 (7.10X-8): Account of grain loan

National Library Register No. 042 (7.10X-8): 7 lines remain legible. Translation:

Weiming "The Old Home" barley principle 5 (dan) ...

Interest 2 dan ...

Wheat principle 2 (dan) ...

Interest 1 dan ... 
Liu "the mountain dog" barley principle 3 (dan) ...

Interest 1 dan

wheat ...

No. 043 (7.10X-8): 6 lines have survived. The following is a literal translation:

Interest 5 dou

Wheat principle 5 dou ...

Interest 2 dou 5

Weiming (née) "the double treasure" barley principle 1 dan 5 ...

Wheat principle 1 dan 5 dou

Interest, coarse grains 1 dan ...

Register 045 (7.13X-1): 2 lines have survived. Here is a literal translation:

Dong "dog of the first month" wheat principle 5 dou

Interest 2 dou 5 sheng

Register No. 051 ( $7.13 \mathrm{X}-2): 5$ lines have survived. Here is a literal translation:

Liu "a little pair" wheat principle 7

Interest 3 dou 5 sheng dou

Zhu "Joy of the last month" wheat principle 5 dou

Interest 2 dou 5 sheng

Moshang "deer-catcher" wheat 5 dou

...



FIGURE 110

National Library of China No. o61 (7.13X-8): Account of grain loan 
Register No. o61 (7.13X-8): 7 lines have survived. Translation:

Interest 3 dou ...

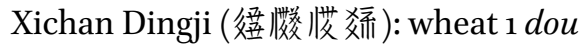

Interest 5 sheng

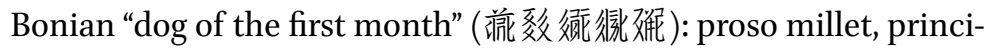
ple 1 dan 5 dou

Interest 7 dou 5 sheng

Wheat principle 1 dan

Interest 5 dou

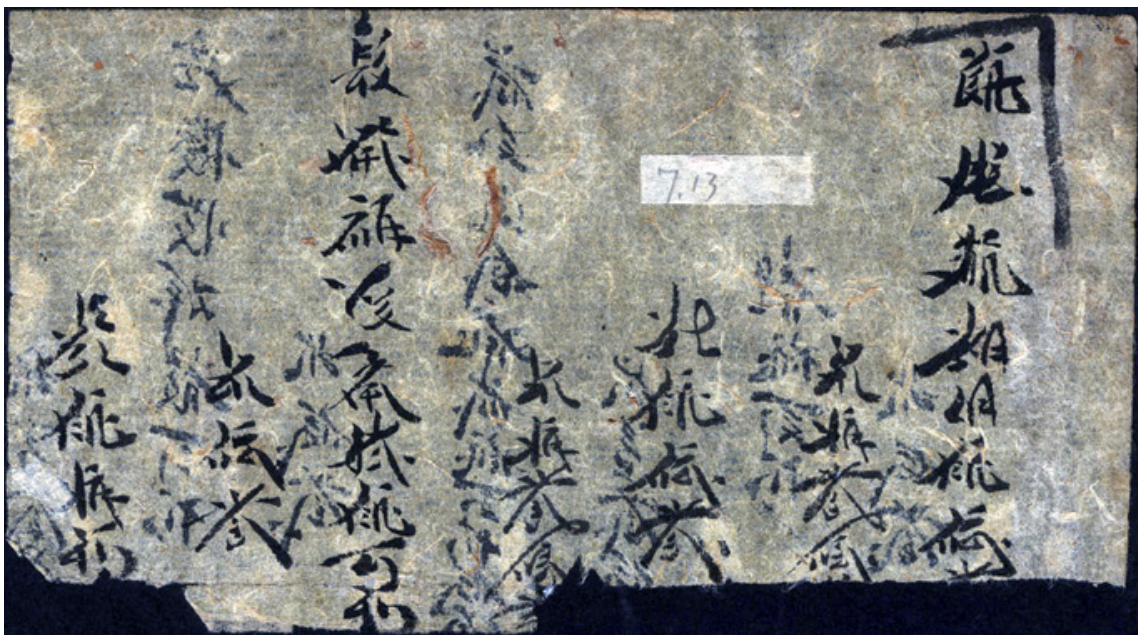

FIGURE 111 National Library of China No. 062 (7.13X-8B): Account of grain loan

Register No. 062 (7.13X-8B): 7 lines have survived. The following is a literal translation:

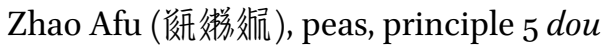

Interest 2 dou 5 sheng

Wheat principle 5 dou

Interest 2 dou 5 sheng

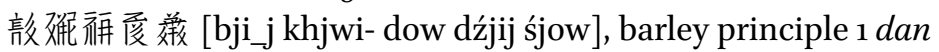

Interest 5 dou

Wheat principle 2 dan

Register No. $055(7.13 \mathrm{X}-4): 5$ lines have survived. The following is a literal translation: 
... ?city ??

... barley principle 1 dan 5 dou

Interest 7 dou 5 sheng

Wheat 3 dan 5 dou

Beans 1 dan 1 dou; beans 1 dan 4 dou

Register No. ${ }_{0} 6$ (7.13X-4B): 6 lines have survived. The following is a literal translation:

... black barley 1 dan 5 dou; wheat 1 dan

Interest 7 dou 5 sheng

Wheat principle 1 dan; wheat 1 dan 3 dou

Interest 5 dou

Barley principle 2 dan; barley 2 dan 2 dou

interest ...

Register No. $039(7.10 \mathrm{X}-5): 5$ lines have survived. The following is a literal translation:

Principle ... principle 350

... wheat and beans, in total, 5 dou proso millet, 2 dou wheat loaned

... month, first day, 15 bundles of hay

... interest there is 3 dou? Barley principle loaned, 4 dou 5 ...

...... cash? 150

Similar registers include No. 48, 49, 50, 51, 52, 53, 54, 57, 58, 59, and so forth. An overview of these documents reveals some commonality: they accentuate the identity of the creditor, record the types of grains involved in the loan concerned, the quantity of the principle, as well as the interest rate therein applied. These are neither proper contracts, nor simply compiled statistics and summaries of contracts. Instead, they seem to be accounts that keep track of 'which creditor retains how many loans,' etc. In this case, then, it is most sensible to speculate that these are accounts of creditors and their loans, kept not by the creditors themselves but by the pawnshops or other financial institutions, for their own information. These agents, in order to manage the assets of multiple creditors, keep these accounts to keep track of the whereabouts of the loans and interests.

A quick glance at the names of the creditors finds quite a number of Dangxiang Tanguts, some of whom are from illustrious families: the royal Weimings, the Yelis who are close kins to the emperors; the glorious Gule, as well 


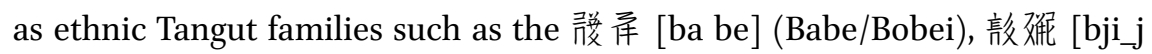
khjwi-] (Mingqu), 湔数 [bə njij] (Bonian), and others. Amongst Han Chinese names are Zhao, Liu, Zhu, Dong, and so on. These are all wealthy households in possessions of surplus grains.

But perhaps more importantly, these accounts provide us with the data, so badly needed, in order to derive the interest rates of grain loans during this period of the Tangut economy. The rather full account in Register No. 043 reads, "wheat principle 5 dou, interest 2 dou \& 5"; No. 045: "Dong 'dog of the first month' wheat principle 5 dou, interest 2 dou 5 sheng"; No. 055 : "barley principle 1 dan 5 dou, interest 7 dou 5 sheng"; No. ${ }_{51}$ "Liu Ache wheat principle 7 dou, interest 3 dou 5 sheng"; No. 051 "Zhu 'Joy of the last month' wheat prin-

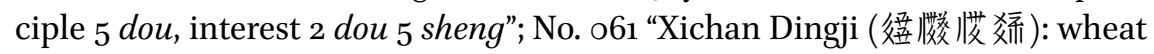

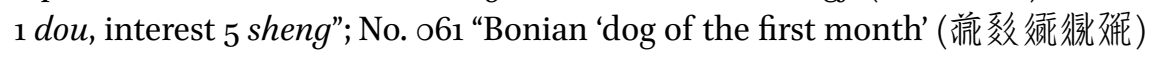
proso millet principle 1 dan 5 dou, interest 7 dou 5 sheng; wheat principle 1 dan, interest 5 dou"; No. o62: "Zhao Afu: peas principle 5 dou, interest 2 dou 5 sheng; wheat principle 5 dou, interest 2 dou 5 sheng”; “敦贿解度麻 [bji_j khjwi- dow dźjij śjow] proso millet principle 1 dan, interest 5 dou"; No. 056: "barley 1 dan 5 dou, interest 7 dou 5 sheng; wheat principle 1 dan, interest 5 dou."

Obviously, regardless of the grain type-whether it is wheat, barley, beans, peas-or the quantity of the loan, the interest rate stabilises at $50 \%$. Most of these documents, however, do not reveal the time or duration of these loans. But we know from extensive readings of Khara-Khoto grain loan contracts preserved in Russia, that most of the contracts are signed in the second month of the year, in the difficult intervening time between two harvests. The debt is due to be repaid by the eighth month, when a new harvest materialises. So, the duration of the loan would encompass the first half of the year. An interest rate of $50 \%$ for a loan that lasts for a half a year is a usurious loan by dictionary definition. Tangut peasants depend on one harvest to pay the land lease, cover the land and irrigation taxes, feed their family in the next six months, and to pay back all that they owe to their exploitative creditors. Such is the degree of poverty and hardship they must have faced.

A rather curious document is the No. 43: "wheat principle 1 dan 5 dou, interest: coarse grains 1 dan ..." So, it does seem that a loan in fine grains can be repaid in coarse grains, but of course at a larger quantity to compensate for the price difference. At the common interest rate, 1 dan 5 dou of principle in wheat would correspond to an interest payment of 7 dou 5 sheng of wheat. But since the borrower repays not in wheat but in coarse grains, in the amount of 1 dan or more, it turns out that there is a surge of $1 / 3$ in the interest rate, when coarse grains are repaid to cover debt in fine grains. 


\subsection{Grain Debts}

There is also a type of 'grain debt account' that, in addition to the parties directly involved in the loan, records the name of a guarantor, and requires the notarisation of a stamp. Therefore, it is also referred to as the "guarantor's account of grain debt," a special, if not unique kind of Tangut legal document. The peasants deeply in debt would have to find guarantors in order to take out loans. This is probably a measure by which the Tanguts tried to manage their taxes and grains. One such example is the Khara-Khoto document Инв. No. 866 "guarantor's account of grain debt," a $21.7 \mathrm{~cm} \times 61.4 \mathrm{~cm}$ manuscript with 26 lines of Tangut cursive writings and the validation of a stamp. ${ }^{62}$

This is an incomplete manuscript fragment of 26 lines, that contain the statistical account of grain debts owed by 4 households in a given liliu district. Lines 1 and 2 start off with the name of the leader in charge of the liliu (lizheng): 舫耏爱 [khji-_dow dźjij] and the name of the liliu under his supervision, followed with a stamp. The account proceeds to the record the statistics by individual households, including the amounts of grains owed, the names of the borrowers (with stamps) and the guarantors (with stamps). For example, in the household No. 1, lines 1-2 state that 後贱形徽 [zjwi. · tśhjwor bie_j] has a patch of 'wet land' (Tangut: 彷俢 [lji-. tsji]), where 10 dan of seeds can be sowed, and which borders a certain canal. Line 3 details the types of grains, barley, and wheat. Line 4 states the following: “One debtor: 㱛微”一that is, the



FIGURE 112 Инв. No. 866: Guarantor's account of grain debt (1)

Russian Collection of Khara-Khoto Manuscripts 12, p. 145. 


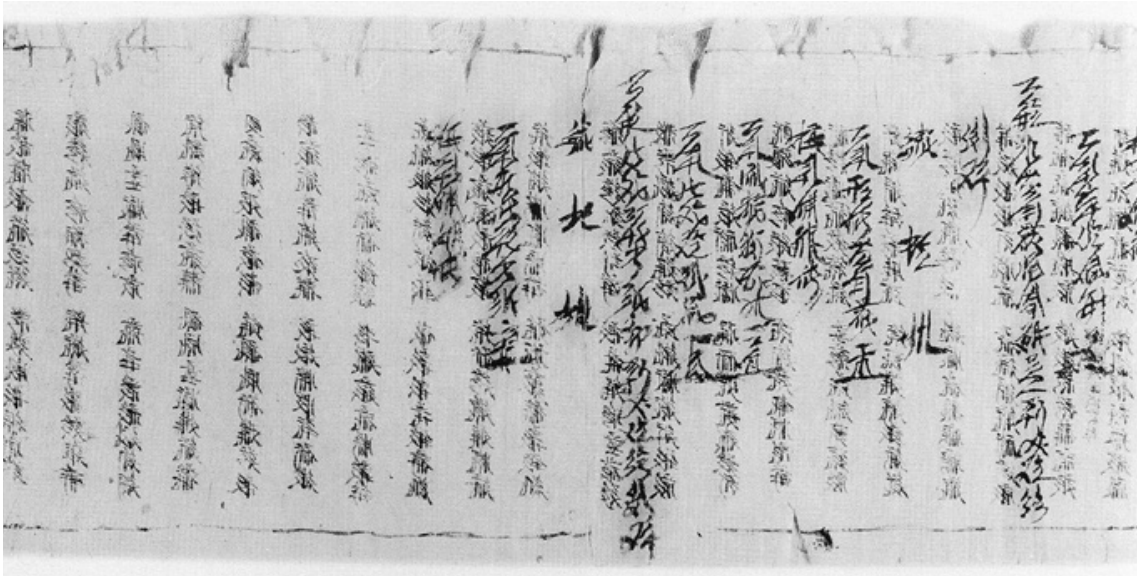

FIgURE 113 Инв. No. 866: Guarantor's account of grain debt (2)

name of the head of the first household, followed by his stamp. Line 5 refers to "two guarantors"; then in lines 6 and 7 are the names and stamps of the two guarantors. The same format is applied to the three following households, all of which owe various amounts of debt. The only variables are the heads of the families (the legal persona owing the debt), the size of their lands, and the identities of the guarantors.

There is, in addition, a similar manuscript Инв. No. 4760, a scroll of 'guarantor's account of grain debt' fragments more than 3 meters long. It contains an incomplete statistical account of the debts owed by 20 households. The $19.7 \mathrm{~cm} \times 303.5 \mathrm{~cm}$ manuscript scroll features 138 lines of cursive Tangut handwritings, with stamps and signatures. ${ }^{63}$

The debtor and the guarantor each provide a signature and a stamp. What is strange about this document is that the loan is written as, "coarse [and] fine [grains] in total [...] dan [...] dou," where the numbers are mysteriously missing. Perhaps the amount of debt in this particular context is simply the total amount of grain dues, which may be a fixed number that does not have to be spelled out in the document. In any case, both the debtor and the guarantor would still have to provide a stamp.

63 Russian Collection of Khara-Khoto Manuscripts 13, pp. 258-262. 


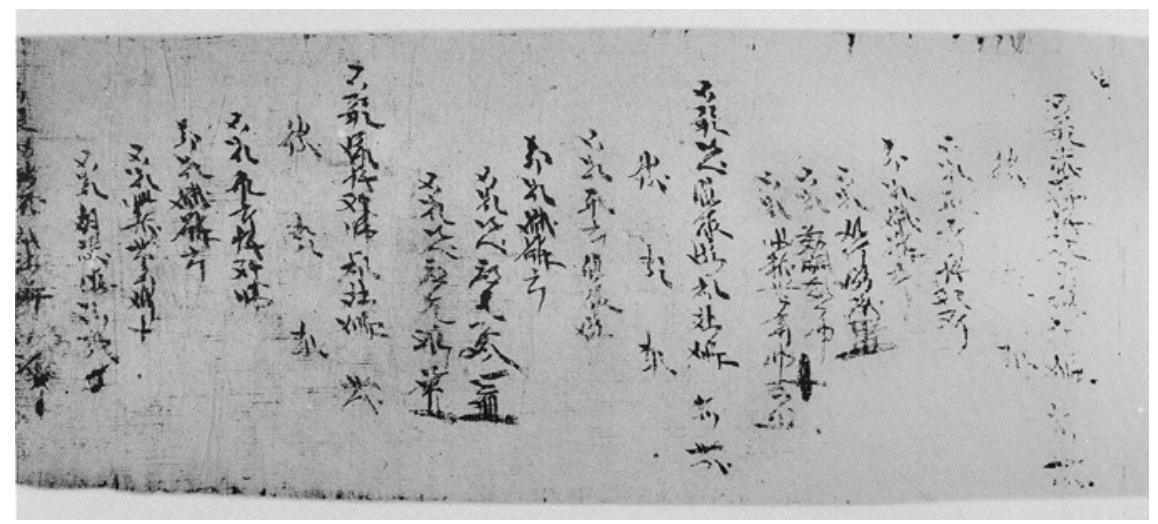

FIGURE 114 Инв. No. 476o: Guarantor's account of grain debt

A batch of Khara-Khoto land sale contracts in the Tangut language have unveiled the colourful practices of land sales in Western Xia. These contracts will be the subject of analysis in the next chapter. But aside from these legal documents, there are also non-contractual documents of land sales that, from a different perspective, offer just as much information on land transactions in Tangut Khara-Khoto.

The manuscript No. 2156-2 is an incomplete account of land sale in the Tianqing era, handwritten on a piece of layering paper in a sutra cover. The manuscript is $23.1 \mathrm{~cm} \times 30 \mathrm{~cm}$ in size, with 11 lines of Tangut cursive writings. ${ }^{64}$

In spite of the incompleteness, and sometimes the illegibility of the manuscript, there is much valuable information on land transactions to be extracted from the document. The following is a selective translation of the first 4 lines of a more important section of the manuscript:

... Tianqing year ... all/each year ...

?length: 165 chi; width: 100 chi? patch ...

265 chi of land, sold as, price 140 ? 65

cash [in] guan already paid ... contract done ... money, land ...

64 Russian Collection of Khara-Khoto Manuscripts 13, p. 30. The title as it appears in the book format is "submission of political report," whereas it is actually a land sales account.

65 TN: It may be the single digit here that is missing. 


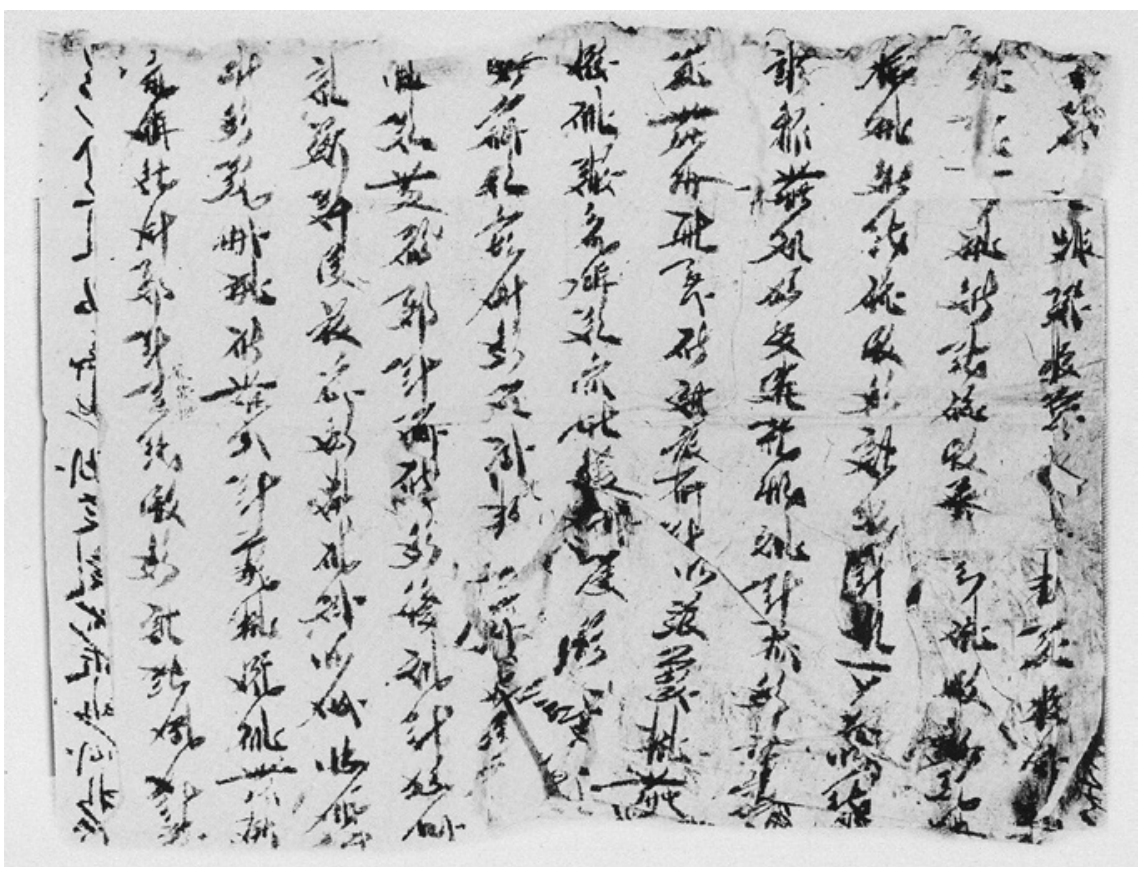

FIGURE 115 Инв. No. 2156-2: Account of land sale in the year of Tianqing

Here, we find the size (length and width) and price of the land, both key data on land sales. The Tangut Sea of Characters offers a precise definition of the unit 'mu': "a land that has each of its sides 50 chi along, and all four sides 200 chi in total, that counts as $1 \mathrm{mu}$."66 Therefore, a Tangut 'mu' corresponds to the size of 2500 square chi, or 25 square zhang, or yet, 100 square bu. Given this data, one could derive that, if 1 Tangut cun is $3.12 \mathrm{~cm}$, a Tangut $m u$ is about 243 square meters. In the Tang and Song system of measurement, $1 \mathrm{mu}$ equals 240 square $b u$, or roughly 6 oo square meters. In other words, 1 Song $m u$ is about 2.4 Tangut $m u$. With this in mind, we know that in the manuscript referred to above, the area of the land sold is $165 \mathrm{chi} \times 100 \mathrm{chi}=16,5$ oo square chi, or 6.6 Tangut $m u$. But the document also mentions that a "265 chi of land" is sold. This number is obviously the sum of the length and the width: $165+100=265$. It is unclear what this addition really amounts to. But since the document also gives the total payment as 140 guan, then the unit price per $m u$ of land is around 21 guan. The price is so high that it does not seem to be a normal patch of farmland.

66 Shi Jinbo; Bai Bin; Huang Zhenhua. Wenhai Yanjiu [文海研究]: A Study on the Sea of Characters. Beijing: China Social Sciences Press, 1983, pp. 316, 534. 
A similar type of manuscript is the Инв. No. 2156-4, also a fragment written on a layering paper of a book, that is $11.3 \mathrm{~cm} \times 28.8 \mathrm{~cm}$ in size, with 10 lines of Tangut cursive writings. ${ }^{67}$

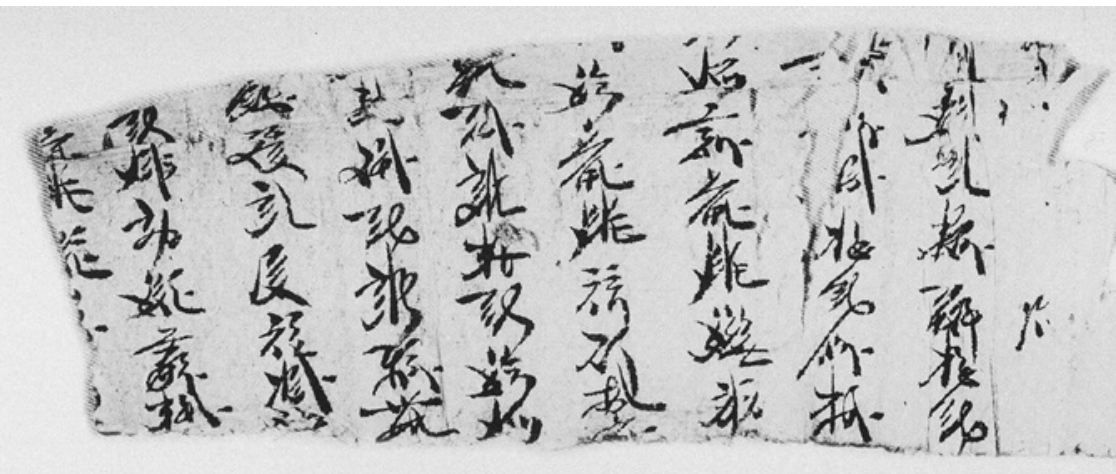

FIGURE 116 Инв. No. 2156-4: Account of land sale

Translation:

... Tiansheng Gengyin twenty ...

... month, twenty-five upon ...

$\cdots$

... land, large, dan, $\mathrm{xx}$ and ${ }^{68}$

... place, already purchased land, four ...

... 310 guan in cash

It is unlikely that any extensive further analysis can come about with this little data and this much damage. But it definitely looks like the same type of document as the account of land sale discussed above. Furthermore, we know at least the year in which the contract is signed: "Tiansheng Gengyin twenty ..." It is most likely to be the 22nd Geng-yin year of Tiansheng (1170).

$67 \quad$ Russian Collection of Khara-Khoto Manuscripts 13, p. 31. The title appears as "submission of a political report," whereas it is actually a land sales account.

68 TN: This line is difficult to crack without more characters. 
A large quantity of commercial documents of Western Xia have survived to this day. In spite of their general state of scars, wears, and tears, they offer a wealth and wide range of information encompassing various sectors of the economy.

(1) The goods featured in the survived commercial documents of Western Xia cover a broad range of daily goods for consumption, such as cloth, silk, and grains. These necessities, the Tanguts could not do away with for a single second in their quotidian lives. There are also goods that bear the marks of ethnic cultures, from alcohol that was popular across ethnic communities, to large and small livestock, which are both factors of production and means of subsistence, as well as the main factors of economic production such as land and human labour.

(2) These commercial records connect the dots between production and consumption. They not only accurately portray the realities of trade and transaction in Western Xia, but also offer the statistics from which a subtler picture of the medieval Tangut economy seems to emerge. Data in transaction accounts, in particular, we now have the market prices of numerous important Tangut commodities, including the prices of grains, livestock, and alcohol. Only when armed with these and such economic data could a historian penetrate into the socio-economic eco-system of the Western Xia.

(3) An inquiry into the Tangut tax documents in previous chapters reveals a great deal about the Tangut taxation on agriculture. The commercial documents, on the other hand, expand the scope of Tangut taxes to other sectors and industries beyond the farmland. The accounts of transaction taxes, in particular, show how the Tangut government tried to intervene with a 'visible hand' and impose taxes upon the circulation of goods in the realm of the market. When it comes to the purchase and sell of cloth, livestock, gold, land, and even human beings, the Tanguts had to pay sales taxes. Land and population are the most heavily taxed. Commercial taxes are a key source of fiscal income for the Tangut local and imperial governments.

(4) The Tangut accounts of loans, interests, and debt document the historically popular practice of loans-cash, grains, and properties-in the Tangut economy. These loans are reflected not only in legally-binding contracts, but also in accounts. In most cases, a single contract is prepared for one particular transaction. The accounts, however, compile the records of multiple loans. In virtue of such a format, the accounts of loans, interests, and debts reveal more general patterns of Tangut loans 
through a macroscopic lens, such as the comparative rates of loan interests. Once compiled and concentrated, economic data can turn into a richer historical narrative.

(5) Most of the taxes referred to in the commercial documents such as the accounts of sales taxes are levied in terms of grains, rather than cash. But other documents, such as accounts of grain sales and accounts of cash and grains, testify to the use of cash currency in real transactions. In alcohol sales, there is a mixed use of cash and grains as methods of payment. In most cases, however, the Tanguts purchased livestock, cloth, and other key commodities by means of grains as a form of currency. The Tanguts minted their own coins, no doubt, but they also circulated Song currencies. But at least the Khara-Khoto region witnessed a mixed currency regime of both cash and grains. 